DP-1356

662944

\title{
GEOCHEMISTRY OF GROUND WATER AT THE SAVANNAH RIVER PLANT
}

\author{
I. W. MARINE
}

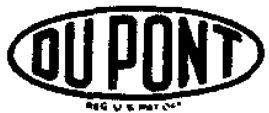

SAVANNAH RIVER LABORATORY AIKEN, SOUTH CAROLINA 29801 


\section{NOTICE}

This report wes prepared as an account of work sponsored by the United States Government. Neither the United States nor the United States Energy Researah and Development Administration, nor any of their contractors, subcontrectors, of their employees, makes any warranty, express or implied, or assumes any legal liability or responsibility for the accuracy, completeness or usefulness of any information, apparatus, product or process disclosed, or represents that its use would not infringe privately owned rights.

Printed in the United States of America

Available from

Netional Technieal Information Service

U. S. Department of Commerce

5285 Port Royal Road

Springtield, Virginia 22161

Price: Printed Copy \$5.50; Microfiche $\$ 2.25$ 
INTERNAL OISTRIBUTION

Copy

1-3. T. B. Niland, SR

4. J. D. Ellett, Wilm

5. H. F. Ring

6. F. E. Kruesi - J. F. Proctor

7. L. C. Evans R. E. Naylor

8. A. A. Kishbaugh

9. W. File

10. L. F. Shafranek, Eng Dept

11. W. J. Mottel - R. Maher, SRP

12. S. Mirshak

13. C. H. Ice - L. H. Meyer, SRL

14. J. L. Crandall

15. T. V. Crawford

16. E. L. Albenesius

17. J. M. Boswell - H. J. Clark

18. W. C. Reinig

19. I. W. Marine

20. H. J. Groh

21. A. S. Jennings

22. R. F. Bradley - H. L. HuII

23. M. L. Hyder

24. R. M. Wallace

25. R. L. Folger - R. S. Dorsett

26. TIS Record Copy

27-50. TIS File
715 Hin

RECORD COPY 


\section{GEOCHEMISTRY OF GROUND WATER AT THE SAVANNAH RIVER PLANT}

by

\section{W. Marine}

Approved by

T. V. Crawford, Research Manager

Environmental Transport Division

Publication Date: September 1976

\section{E. I. DU PONT DE NEMOURS AND COMPANY SAVANNAH RIVER LABORATORY}

AIKEN, SOUTH CAROLINA 29801

PREPARED FOR THE U. S. ENERGY RESEARCH AND DEVELOPMENT AOMINISTRATION UNDER CONTRACT ATIO7-2)-1 


\section{ABSTRACT}

Subsurface hydrogeologic systems underlying the Savannah River Plant (SRP) were studied to determine the origin and age of the contained fluids. Three distinct systems exist beneath SRP: the Coastal Plain sediments, crystalline metamorphic basement rock, and a Triassic rock basin surrounded by the crystalline rock. The water in the Coastal Plain sediments is low in dissolved solids ( $\sim 30 \mathrm{mg} / 1$ ), acidic ( $\mathrm{pH} \sim 5.5$ ), and comparatively recent. Water in the crystalline rock is high in dissolved solids ( $~ 6000 \mathrm{mg} / 1$ ), alkaline ( $\mathrm{pH} \sim 8)$, and $\sim 840,000$ years old as determined by helium dating techniques. Water in the Triassic rock is highest in dissolved solids $(\sim 18,000 \mathrm{mg} / 1)$ and is probably older than the water in the surrounding crystalline rock; a quantitative age was not determined. The origin of the water in the crystalline and Triassic rock could not be determined with certainty; however, it is not relic sea water. A detailed geologic-hydrologic history of the SRP region is presented. 
Figure

1 Generalized NW to SE Geologic Profile Across SRP 9

2 Map Showing Sources of Water Analyzed for Chemical or Isotopic Compositions 15

3 Changes in Water Chemistry from Long-Term Discharge of WelT DRB 622

4 Changes in Water Chemistry with Depth in We11 DRB 822

5 Water-Transmitting Fractures in Well DRB 824

6 Changes in water Chemistry of We 11 DRB 8 with Removal of Injected Fresh Water 25

7 Geophysical Log of the Self-Potential of Well DRB 1128

8 Map Showing Dissolved Oxygen and Sulfate Ion Concentrations in Waters from the Coastal Plain Sediments 30

9 Piezometric Map of Water in Crystalline Metamorphic Rock and Inferred Flow Paths 32

10 Ionic Ratios of Selected Ground Water Samples at SRP 35

11 Isotopic Ratios for Deuterium and 0xygen-18 for Water Samples from Vicinity of SRP 38 


\section{INTRODUCTION 7}

SUMMARY 9

ANALYSES AND SAMPLING 14

Analyses 14

Dissolved Solids 14

Dissolved Gases 16

Isotopic Ratios 17

Other Analyses 18

Sampling and Analytical Validity 18

Analysts 19

GEOCHEMICAL ANALYSES 20

Surface Water 20

Water from Coastal Plain Sediments 20

Water from Crystalline Metamorphic Rock 21

Water from Triassic Rock 26

INTERPRETATION OF THE GEOCHEMICAL ANALYSES 29

Surface Water and Coastal Plain Sediments 29

Crystalline Metamorphic Rock 31

Hydrologic History 31

Dissolved Solids 33

Isotopic Ratios 37

Radioisotope Dating 39

Gas Analyses and Helium Determined Age 41

Saprolite 46

Triassic Rock 47

CONCLUSIONS 50

TABLES $\quad 52-96$

APPENDIX: Data on Water Injected and Removed during Drilling and Testing, January 1961 through JuTy $1973 \quad 97$

REFERENCES 101 
Table

1 Analyses of Water from Surface Sources 52

2 Analyses of Water from Coastal Plain Formations 56

3 Analyses of Water from Crystalline Metamorphic Rock 63

4 Analyses of Water from Triassic Rock 75

5 Analyses of Saprolite and Crystalline Metamorphic Rock 80

6 Isotopic Composition of Argon Dissolved in Water from the Crystalline Metamorphic Rock Compared with the Isotopic Composition of Argon in Air 83

7 Thorium, Uranium, and Helium Contents of Selected Core Samples of Crystalline Metamorphic Rock 83

8 Ratio of ${ }^{34} \mathrm{~S} /{ }^{32} \mathrm{~S}$ in Sulfide Minerals in Crystalline Metamorphic Rock Compared to that of Sulfate in Water 84

9 Range and Median Values for Chemical Constituents and Properties of Water from Coastal Plain Sediments 85

10 Generalized Log of Saprolite Cores 86

11 Analyses of Pore Water from Saprolite 87

12 Electrical Conductivity of Water from Well DRB 1188

13 Geologic Formations Underlying SRP 89

14 Geologic-Hydrologic History of the SRP Region 90

15 Analyses of Leach Solutions from Ground Rock 92

16 Selected Analyses of Effervesced Gas from Wells in Crystalline Metamorphic Rock 93

17 Gases Dissolved in Water Samples from Wells DRB 6 and DRB 794

18 Analyses of Pore Water from Tuscaloosa and Triassic Rock Samples 95

19 Analyses of Dissolved Gas in Water from Triassic Rock 96 


\section{GEOCHEMISTRY OF GROUND WATER AT THE SAVANNAH RIVER PLANT}

\section{INTRODUCTION}

During the Bedrock Waste Storage Exploration Program at the Savannah River Plant (SRP), a number of surface and ground water samples were analyzed to determine isotopic composition, dissolved solids, and dissolved gases. These analyses were made to interpret the age and origin of water in the bedrock (Triassic and crystalline metamorphic rocks). In addition to water samples collected from the bedrock, samples were collected on a periodic basis from surface sources and from aquifers in the Coastal Plain sediments. Samples of water from the bedrock date back to the early phases of exploration in 1961-62, but periodic surface and ground water sampling did not begin until the spring of 1971. In the fall of 1972 , the Bedrock Waste Storage Exploration Program was indefinitely postponed, and, as a result, the periodic sampling of surface water and ground water was terminated. A few water samples from the Triassic and crystalline rock wells became available after the well drilling was completed, and a final round of collecting samples was made. Rock specimens were also collected from the well cores for geochemical analysis.

The purpose of this report is to tabulate all the water and rock analyses that may be useful for subsequent geochemical interpretation. In addition to reporting the basic data, this report also provides some preliminary and elementary interpretations of the data in regard to the origin and age of the various waters. These interpretations are not meant to be exhaustive, but to present the conclusions reached at the time that work on the project was terminated.

The report is arranged into three major sections. The first, entitled Analyses and Sampling, discusses the general usefulness of the types of geochemical analyses that are included and the problems of obtaining representative samples. The second section, entitled Geochemical Analyses, discusses individual analyses and sequences of analyses and their meaning related to their specific source, i.e., individual well or creek. The third section, entitled Interpretation of the Geochemical Analyses, discusses the interpretations of the analyses in terms of conceptual models of the various geohydrologic systems. 


\section{GEOLOGIC AND HYDROLOGIC SYSTEMS}

Three distinct geologic and hydrologic systems (Figure 1) exist beneath SRP: (1) the Coastal Plain sediments of Cretaceous and Tertiary age (Eocene and Miocene on Figure 1), where water occurs in porous, unconsolidated to semi-consolidated sand and clay; (2) the buried crystalline metamorphic basement rock consisting of chlorite-hornblende schist, hornblende gneiss, and lesser amounts of quartzite, where water occurs in small fractures; and (3) a buried Triassic basin, consisting mostly of red corsolidated mudstone with some poorly sorted sandstones, where water occurs in the intergranular space, but is very restricted in movement due to the extremely low permeability.

To these three sources of water samples may be added a fourth: the surface streams that drain the region. However, much of the water that flows in streams, especially in dry weather, has passed through the ground for some indeterminate distance and time prior to its presence in the channel of a stream. Thus, surface water and the shallow ground water in the Coastal plain formations are not separate and distinct, but part of the same system.

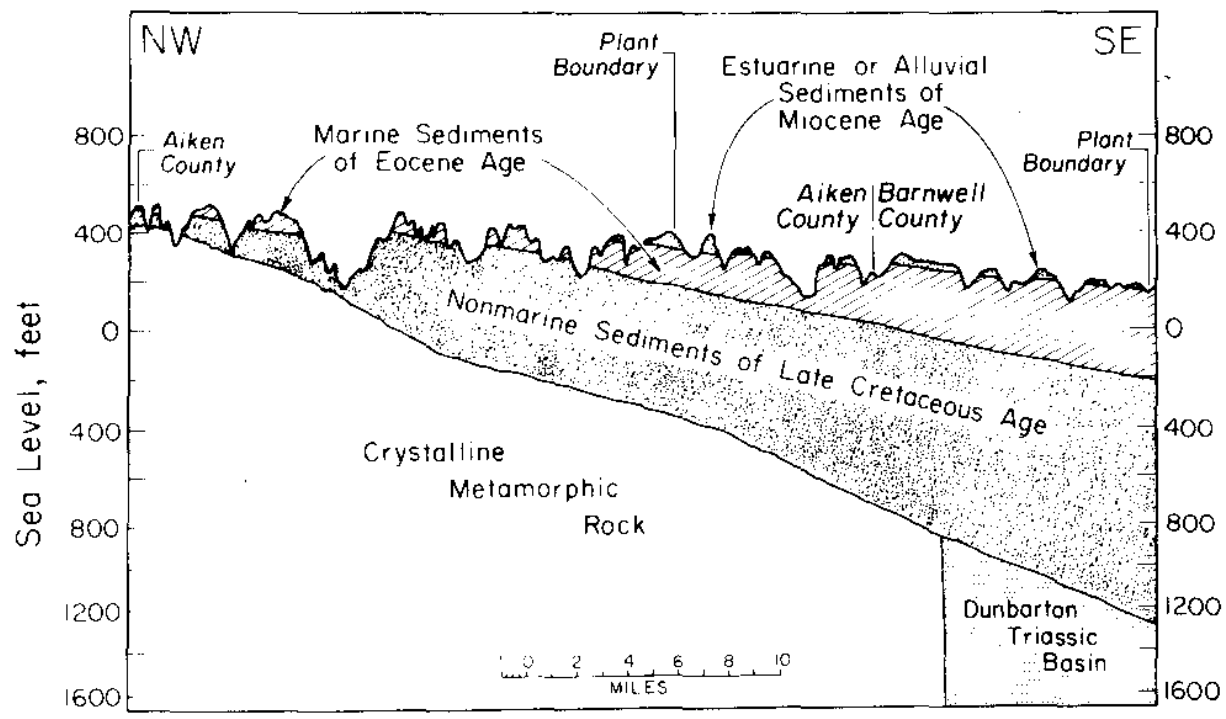

FIGURE 1. Generalized NW to SE Geologic Profile Across SRP 
Dissolved Solids

Water in the Coastal Plain formations is low in dissolved solids ( $230 \mathrm{mg} / 1)$, acidic $(\mathrm{pH} \sim 5.5)$, and aggressive in its attack on metallic surfaces. In places, the water from the Coastal Plain formations is saturated with dissolved oxygen ( $\sim 9 \mathrm{mg} / 1$ ) and has a very low sulfate content $(<2 \mathrm{mg} / 1)$ to depths as great as 800 feet (Tuscaloosa aquifer). In other areas, the oxygen apparently has reactcd with sulfide minerals in the rock, completely depleting the oxygen $(\sim 0 \mathrm{mg} / 1)$ and raising the sulfate content $(13 \mathrm{mg} / 1)$. The demarcation line between these two areas is sharp and distinct, and may be an oxidation front that is moving in the direction of ground water flow but at a much slower rate.

The Coastal Plain sediments are separated from the crystalline metamorphic rock by about 80 feet of residual weathered crystalline rock called saprolite. Chemical analyses of the saprolite show clearly the weathering profile by the progressive upward leaching of iron(II), magnesium, calcium, and sodium and, also, the increasing hydration of minerals from bottom to top of the saprolite layer. The dissolved solids content of the water changes abruptly across the saprolite layer from $30 \mathrm{mg} / 1$ at the basal Coastal Plain interface to $3500 \mathrm{mg} / 1$ at the top of the crystalline metamorphic rock. Analyses of the very small quantities of water squeezed from cores of the saprolite were not sufficiently accurate to determine where or how this change of water quality occurred within the saprolite.

The water from the crystalline metamorphic rock is high in dissolved solids $(6000 \mathrm{mg} / 1)$ consisting almost entirely of calcium $(500 \mathrm{mg} / 1)$, sodium $(1400 \mathrm{mg} / 1)$, sulfate $(2300 \mathrm{mg} / \mathrm{t})$, and chloride $(1400 \mathrm{mg} / 1)$. Because there are no identifiable chloride-containing minerals in the rock, and because a leach solution from distilled water and ground-up crystalline metamorphic rock contained very little chloride, a source for the water other than rain is suggested. Sea water is an a prioni candidate source. However, the geologic history of the area and the required hydraulics of sea water intrusion make this hypothesis nearly untenable. Chemical analyses of the rock do indicate the presence of a very slight amount of chloride, and additional experiments of longer duration with leach solutions might indicate the rock itself to be the source of chloride.

Although some question remains on the origin and paleohydrology of the water in the crystalline metamorphic rock, its general flow pattern at the present time is known. Flow originates in the vicinity of the Fall Line, moves in an arcuate path passing beneath the Savannah River Plant, and discharges upstream into the Savannah River 
valley. Water is estimated to have been in the crystalline metamorphic rock for 840,000 years, and if a flow path of 32 miles from the outcrop area is assumed, the water has traveled at an average rate of $0.2 \mathrm{ft} / \mathrm{yr}$.

Water from the Triassic rock is higher in dissolved solids $(18,000 \mathrm{mg} / 1)$ than the water from crystalline metamorphic rock $(6000 \mathrm{mg} / 1)$. The dominant cations are calcium $(4600 \mathrm{mg} / 1)$ and sodium $(2900 \mathrm{mg} / 1)$, and the dominant anion is chloride $(10,000 \mathrm{mg} / 1)$. sulfate is very low $(\sim 0 \mathrm{mg} / 1)$, as are most other constituents.

The two wells in the Triassic basin that have the highest dissolved solids content also have hydraulic heads that are well above land surface. The preservation of these heads in the Triassic basin, when surrounded by much lower heads in the overlying Coastal Plain and metamorphic rock attests to the impermeability of the Triassic rock. These heads do not originate from the water-level elevation in a recharge area, from relic head from some previous loading, from compaction of sediments, or from any of several endothermic chemical reactions that can release free water. The hydraulic heads in the two wells are different and are in proportion to their dissolved solids contents. The hydraulic head in each well approximates that which would balance osmotic forces caused by a semipermeable membrane separating aqueous solutions identical to the water in the Coastal Plain sediments and the water in the Triassic rock. As would be expected if osmosis were the cause of these heads, wells near the vertical and horizontal margins of the Triassic basin are lower in dissolved solids and have lower hydraulic heads.

\section{Dissolved Gases}

The water from the crystalline metamorphic rock contains dissolved gas, most of which is nitrogen ( $293 \%$ ); however, it also contains a significant quantity of helium $(\sim 6 \%)$, which could not have an atmospheric origin. The helium content provides a method for dating the water because its generation rate from the decay of uranium and thorium in the rock is known. Only about $7-1 / 2 \%$ of the helium found is contained in the water, the remainder being in the rock itself. Eleven million years would be required to generate all of the helium found.

Because water from the crystalline metamorphic rock contains no tritium, this water has been in the ground more than forty years. 
Gas that effervesces from one of the Triassic wells is about $2 / 3$ hydrogen and about $1 / 3$ nitrogen. Although the origin of this gas is not known, gas derived from coal in the nearest outcropping Triassic basin in North Carolina has about the same ratio of hydrogen to nitrogen.

\section{Isotopic Ratios}

Isotopic ratios of deuterium to hydrogen and oxygen-18 to oxygen-16 of surface and ground water samples reflect the evaporation that occurs at Clark Hill Reservoir on the Savannah River and at Par Pond on Lower Three Runs Creek. Surface streams, a11 of which are supported by influent ground water seepage (especially during dry periods), have isotopic ratios and dissolved solid constituents that are similar to those of ground water in the Coastal plain formations.

Isotopic ratios of deuterium to hydrogen and oxygen-18 to oxygen-16 indicate that the water from the crystalline rock cannot be a simple mixture of rain water and sea water. However, these ratios follow the same pattern as the water from the Coastal plain sediments, indicating that the Coastal Plain sediments may be the source, even though the water has undergone many modifications after entering the crystalline metamorphic rock.

Isotopic ratios of sulfur-34 to sulfur-32 from the sulfate in the water and the sulfide minerals in the crystalline rock indicate an external source for the sulfate in the water, but also indicate that the water from the Coastal Plain. sediments could be this source instead of relic sea water.

A graph of the ionic ratios indicates that the water now found in the crystalline rock is not similar to modern sea water nor is it similar to the short-term leach solution obtained from distilled water and ground-up crystalline metamorphic rock. However, if some calcium and chloride were precipitated or some sodium and sulfate added, the present water could be a mixture of these two waters. Based on the ionic ratios, the crystalline rock water cannot be a mixture of Coastal Plain water and sea water.

Because the bicarbonate content of the water $(16 \mathrm{mg} / 1)$ is very low, dating the water by carbon-14 methods was not successful.

Potassium-argon determinations on the crystalline rock indicate that its last metamorphism was during the Appalachian mountain deformation in late Pennsylvanian or Permian time. However, the age of the rock has little bearing on the age of the water. 
The several techniques applied to decipher the origin of the water in the crystalline rock yield contradictory results when the question is asked in simple terms: Is this water from rain, sea water, or the Coastal Plain formations? The water now found has been greatly modified during its 840,000 year travel time, and its genesis is masked by the characteristics acquired since its origin.

The dissolved solids content and particularly the chloride content of water from the Triassic basin have led to speculation of a sea water origin. However, the chloride content of the water may be derived from the solution of chloride minerals in the Triassic rocks. Even though no chloride minerals have been determined in the Triassic basin exploration at the Savannah River Plant, some are known from other Triassic basins. The iodine-chlorine ratio of the water from the Triassic basin is about 30 times greater than that of sea water. Ionic ratios and isotopic ratios also indicate that this water is not sea water, nor is it a simple mixture of sea water and rain water, nor sea water and water from the Coastal Plain sediments. 
ANALYSES

The objective of this section is to discuss generally the purpose for which certain types of analyses are made and to introduce the tables of analyses, which are at the end of the report.

The tables of analyses are categorized according to four principal sources: Table 1, water from streams and rivers; Table 2, water from the Coastal Plain sediments; Table 3, water from the crystalline metamorphic rock; and Table 4, water from the Triassic basin rock. Water from the Coastal Plain sediments are further distinguished between the two major water-bearing units: the McBean and Congaree formations of Eocene age, and the Tuscaloosa formation of Late Cretaceous age (Figure 1). Water samples from the exploration wells in the Triassic basin and crystalline metamorphic rock were analyzed when they became available through specific drilling or testing programs. Periodic samples were obtained every three months from six wells in the Coastal Plain sediments (Table 2) and from four surface streams that drain the area (Figure 2). These water samples were analyzed for dissolved solids; dissolved gases; isotopic ratios of oxygen, hydrogen, and sulfur; $\mathrm{pH}$; and specific conductance.

Rock samples were analyzed for elemental composition (Table 5) and for isotopic ratios.

Dissolved Solids

Dissolved solids are those constituents that when not dissolved in water are normally in the solid phase. Several constituents normally make up the largest part of the solute in natural water, namely, $\mathrm{SiO}_{2}$; the cations $\mathrm{Mg}, \mathrm{Ca}, \mathrm{Na}, \mathrm{K}$; and the anions $\mathrm{HCO}_{3}, \mathrm{SO}_{4}$, and $\mathrm{Cl}$. Other constituents may be important to the geochemistry of the water, even though they are not present in large amounts. Where a constituent is commonly reported, it is listed on the appropriate table. If a constituent is reported for only a few analyses, it is listed under remarks. Compositional analyses are expressed as milligrams of dissolved substance per liter of water. 


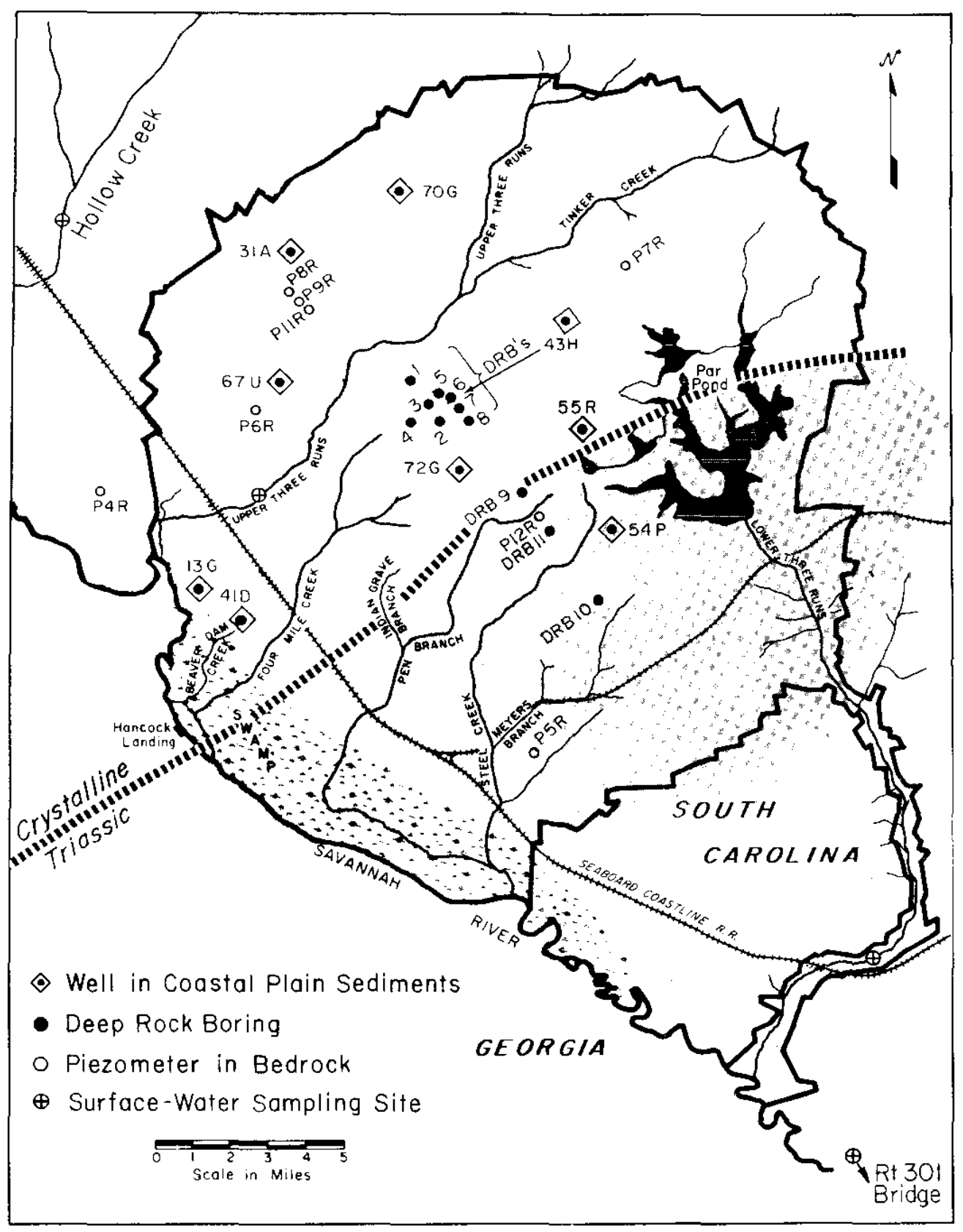

FIGURE 2. Map Showing Sources of Water Analyzed for Chemical or Isotopic Compositions 
Dissolved solids are present in small amounts in water from rainfa11, but commonly the soil 1 zone adds much more. Thus, surface water will have a dissolved solids content that varies widely depending on the duration of its contact with the soil zone and the character of the soil zone. In addition, activities of man on some streams commonly contribute to the character, magnitude, and variation of the dissolved solids load.

Much of the water that falls on the land runs off, but some of it reaches the ground with its residence time being a function of the depth and permeability of the body of rock through which it moves. Some water enters the soil zone, percolates a short distance, and reemerges as overland runoff. Other water penetrates deeper and resides in the ground for tens of years, to centuries, and even up to millions of years. Obviously, water that spends much time in contact with rocks will eventually reach chemical equilibrium with them; however, some of its original characteristics may be preserved. For instance, the chloride ion is quite soluble in water, yet is not present in the most common rockforming minerals, except for salt itself. Thus, the presence of abundant chloride in the absence of rock salt may indicate that chloride was present in the source water before it entered the ground. If there is no high chloride source at the present time, the chloride concentration may indicate that the water originated at the surface when conditions were quite different from those of today, possibly when the sea covered the area. Thus, the dissolved solids content coupled with known geologic history may indicate the age as well as the origin of the water.

\section{Dissolved Gases}

Dissolved gases are those constituents that when not dissolved in water are normally in the gas phase. The analyses for dissolved gases are reported for specific sources in Tables 1, 2, 3 , and 4. Oxygen and carbon dioxide are reported in parts per million (ppm); all other dissolved gases are reported as mole percent (mol \%). Rainfall is normally saturated with atmospheric gases, principally nitrogen, oxygen, and argon. As the water passes through the ground, nitrogen, which is relatively inert, can have its ratio to other gases change only by reactions of the more chemically active gases. Oxygen is of course quite reactive, and amounts of dissolved oxygen would be expected to be quite low; yet certain waters in the deep Coastal Plain sediments, which are probably several centuries old, are essentially saturated with oxygen, indicating that the sediments are either inert, or that the possible reactions have already taken place to completion over the centuries that the oxygen-saturated water has flowed through the rocks. 
Argon is inert, and most water samples contain the expected mol $\%$ argon from atmospheric saturation. The air origin of argon is also supported by comparing its isotopic composition as dissolved in water with its isotopic composition in air (Table 6).

Organic reactions in the soil zone and to a much lesser extent in deeper rocks may produce carbon dioxide and methane, and these constituents may be carried to greater depth by ground water circulation. Hydrogen, as well as some nitrogen, may also result from organic reactions in the rocks.

Helium, which is a dissolved constituent of water from Triassic rock and crystalline metamorphic rock (Tables 3 and 4 ), cannot be a constituent from the atmosphere, but must originate from the radioactive decay of uranium and thorium in the rock. Thus, the dissolved helium content in the water, coupled with certain hydrologic knowledge, permits a quantitative calculation of the age of the water. In addition to uranium and thorium contained in the rock, the quantity of helium dissolved in the rock itself is also of interest (Table 7).

\section{Isotopic Ratios}

A straight line relationship exists for the enrichment of deuterium and oxygen-18 concentrations (Tables 1-4) in the natural meteoric waters (relative to that of standard mean ocean water) if excessive evaporation has not taken place. ${ }^{1}$ Enrichments in both of these isotopes vary according to the temperature of precipitation (latitude), but the relationship is generally constant. Excessive evaporation may cause greater relative enrichment of ${ }^{18} \mathrm{O}$ than ${ }^{2} \mathrm{H}$, and thus cause a departure from the "World Precipitation Line." Using this, the isotopic ratio may indicate the origin and possibly the age of the water if the Pliestocene climate was vastly different in evaporation than the present climate.

Sulfur isotopic ratios $\left({ }^{34} \mathrm{~S} /{ }^{32} \mathrm{~S}\right)$ may be used to infer the origin of water; however, many reasons for changes of this ratio are poorly understood. The comparison of the isotopic ratio of sulfur in the sulfate in water (Tables 1-4) and the sulfide minerals in the rock (Table 8) should readily show whether dissolution of rock minerals was the source of the sulfate in the water.

The isotopic composition of oxygen and hydrogen is reported as parts per thousand deviation from standard mean ocean water; ${ }^{2}$ for sulfur, it is parts per thousand deviation from Canyon Diablo Troilite. 
Other Analyses

The acidic nature of the water samples was measured as $\mathrm{pH}$. Specific conductance is given in micromhos per centimeter at $25^{\circ} \mathrm{C}$, and hardness is expressed in terms of the equivalent $\mathrm{mg} / \mathrm{l}$ of calcium carbonate.

SAMPLING AND ANALYTICAL VALIDITY

The objective of collecting and analyzing ground water samples is to determine the composition of water that naturally resides in a part of a body of rock or to trace the history of fluids that have been intentionally or inadvertently injected into the body of rock. Water samples have been collected for both purposes at SRP.

To determine the composition of the native water, it is absolutely essential to know the history of fluid injection and removal before the assumption can be made that a particular sample is representative of the native water. This is a most stringent requirement where the amount of water in the rock is smal1, as it is in the Triassic and crystalline metamorphic rocks. Many of the water samples collected during the early phases of the exploration of the crystalline metamorphic rock do not represent the composition of native water because of the large volumes of fresh water that were injected into the rock during the drilling process. In addition to drilling, many tests that have been performed on the exploration wells for other purposes have disturbed the chemical or isotopic composition of the water produced by the well. A summary of these activities and the volumes of water injected and removed are cited in the Appendix. The history of each well and the probability of contamination must be considered before using these data to interpret the geohydrologic history of the area.

Because of the difficulties experienced in obtaining reliable water samples when water was used as a drilling fluid, air was used as a drilling fluid on all wells drilled from 1967 through 1971. Although using compressed air as a drilling fluid eliminated contamination of the formation with foreign fluids, it thoroughly aerated any water samples collected during the driling process. The saturation of the water specimens with air probably caused an alteration of $\mathrm{pH}$ and perhaps other values. However, samples taken from air-drilled wells are considered more representative than samples taken from the water-drilled wells. The most reliable samples are those that were later pumped or drawn from a well that was drilled with air. The wells drilled in 1972 (P12R, DRB 11) were completely cored using a wire-lined core barrel with water as 
the drilling fluid. However, one well (P12R) was evacuated of fluid as soon as it was completed, and the other well (DRB 11) had a head above land surface; thus, no contamination of the formation (Triassic) occurred.

For most of the bedrock samples where the dissolved solids concentration was high, the chemical balance of cations and anions reported was very nearly equal. However, in many of the analyses of surface water and water from Coastal Plain sediments, where the dissolved solids concentration is low and approached the analytical limit for the constituent reported, the chemical balance is poor. These latter analyses still indicate the correct order of magnitude of the concentration of the constituents.

\title{
ANALYSTS
}

The analyses reported herein were made by many different laboratories and each is identified by the following abbreviated form:

\author{
ANL - Argonne National Laboratory, Chicago, IL \\ $B C L$ - BC Laboratories, Bakersfield, CA \\ Bu Mines - U. S. Bureau of Mines, Amari110, TX \\ Geochron - Geochron Laboratories, Blackstone, MA \\ McCreath - Andrew S. McCreath and Sons, Inc. Harrisburg, PA \\ Scripps - Laboratories of Prof, Harmon Craig at Scripps \\ Institute of Oceanography, La Jolla, CA \\ SRL - Savannah River Laboratory, Aiken, SC \\ SRP - Savannah River Plant, Aiken, SC \\ USGS - U. S. Geological Survey, Water Resources \\ Division Laboratory, Denver, CO; Raleigh, NC; \\ or Washington, DC
}




\section{SURFACE WATER}

Periodic samplings of surface water at quarterly intervals at the four locations shown on Figure 2 are reported on Table 1. These locations are:

(1) Hollow (Holley) Creek at the bridge on S. C. Highway 125, 3 miles north of the SRP boundary.

(2) Upper Three Runs Creek at the bridge on S. C. Highway 125.

(3) Lower Three Runs Creek at the bridge on S. C. Highway 125.

(4) The Savannah River at the bridge on U. S. Highway 301,38 miles by river below the mouth of Upper Three Runs Creek.

\section{WATER FROM COASTAL PLAIN SEDIMENTS}

The analyses of water from the Coastal Plain formations are presented in Table 2. Part A presents periodic analyses from one well that penetrates the McBean formation and five that penetrate the Tuscaloosa formation. All of the periodic analyses are on samples collected from wells that are pumped continually. Part B presents analyses of water from selected wells in the Coastal plain formations. The selected wells in the Tuscaloosa formation are pumped continually; however, the samples from selected wells in the McBean formation are from wells that had not been pumped for a period of years. These samples were collected in the vicinity of the bottom of the wells by a sampler on a cable.

Additional analyses of water from SRP water supply wells, both in the McBean and Tuscaloosa formations, exist but are not reported here. Water from these wells has been analyzed on a periodic basis since construction of SRP began in 1951. Some maximum, median, and minimum chemical analyses of Coastal plain water are shown in Table 9 .

The upper surface of the crystalline rock, where it is in contact with the Coastal Plain sediments, is intensely weathered, forming a buried saprolite. The saprolite is divisible into four units as shown in Table 10. Chemical analyses of samples from these units of saprolite are also given in Table 5. Because of 
the vast difference in chemical characteristics of water from the Coastal plain sediments and water from the crystalline metamorphic rocks, and the fact that the transition occurs within the saprolite, chemical analyses of water within the saprolite are of particular interest. Because of its low permeability, water cannot be pumped from the saprolite. However, attempts have been made to squeeze water from clayey samples of saprolite and to analyze them by neutron activation, $x$-ray fluorescence, and atomic adsorption. The results are presented in Table 11.

\section{WATER FROM CRYSTALLINE METAMORPHIC ROCK}

Isotopic ratios, dissolved gases, and dissolved solids were determined on water samples from crystalline metamorphic rock (Table 3). The most reliable analysis of dissolved solids for each wel1 is ordinarily the latest one listed, as many of the early samples were contaminated with drilling water. For several of the wells (DRB 1, DRB 2, DRB 3, DRB 4, and DRB 7), this water may never have been pumped out, so even the latest sample listed may not be an indication of native water in the rock. Consequently, final samples from DRB 6 and DRB 8 are considered as the most, if not the only, reliable samples taken from the small area labeled "DRB's" in Figure 2.

The relatively unchanging chemical character of water pumped from DRB 6 during a two-year tracer test, ${ }^{3}$ in which water was pumped through a plastic pipe from DRB 6 to DRB 5 and injected into DRB 5, is shown in Figure 3 . Much of this water moved through the ground back to DRB 6. After some changes in the chemical analyses of water at the very beginning of the test, the largest change occurred between the transmittal of two batches of samples and was attributed to an interim change in analytical.techniques. After pumping for 2 years, the test was terminated, and the well field was idle for another 2 years. During this two-year period of no pumping, there was very little change in the chemistry of the water. A 1-year pumping test was then begun in which water was discharged from DRB 6 to waste. Even during the 1-year pumping test, the largest change was an analytical one between two batches of samples.

We11 DRB 8 afforded an ideal opportunity to determine whether the water in the crystalline metamorphic rock was stratified vertically. The well was drilled with compressed air as the circulating fluid; thus water samples taken during drilling were uncontaminated. The water chemistry changed very little with increasing depth as well DRB 8 was being drilled (Figure 4). The deeper samples are composites of all of the water yielded by the well to that depth. However, the yield of each fracture was greater than the one above it, so that if the water in each fracture were 


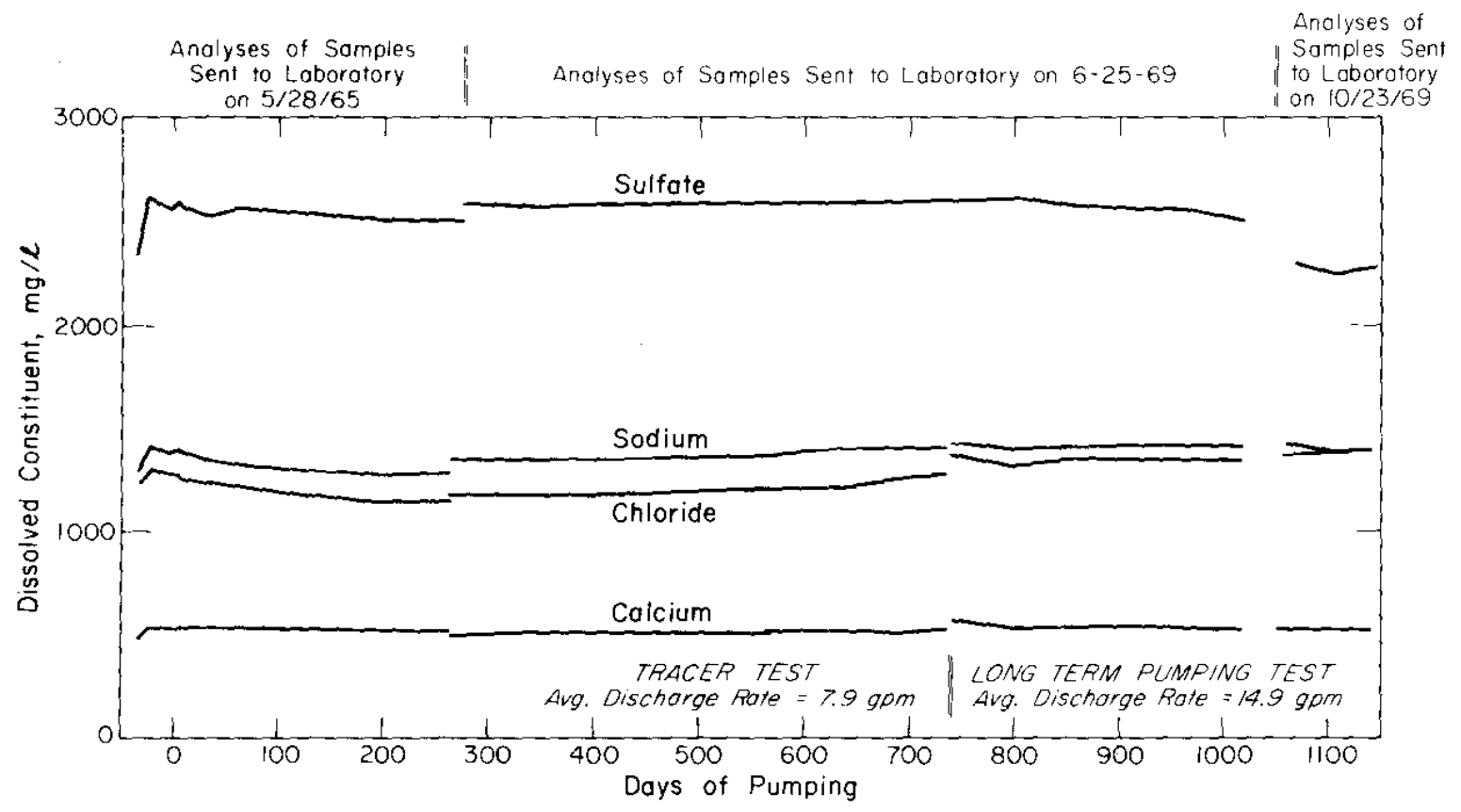

FIGURE 3. Changes in Water Chemistry from Long-Term Discharge of We 11 DRB 6

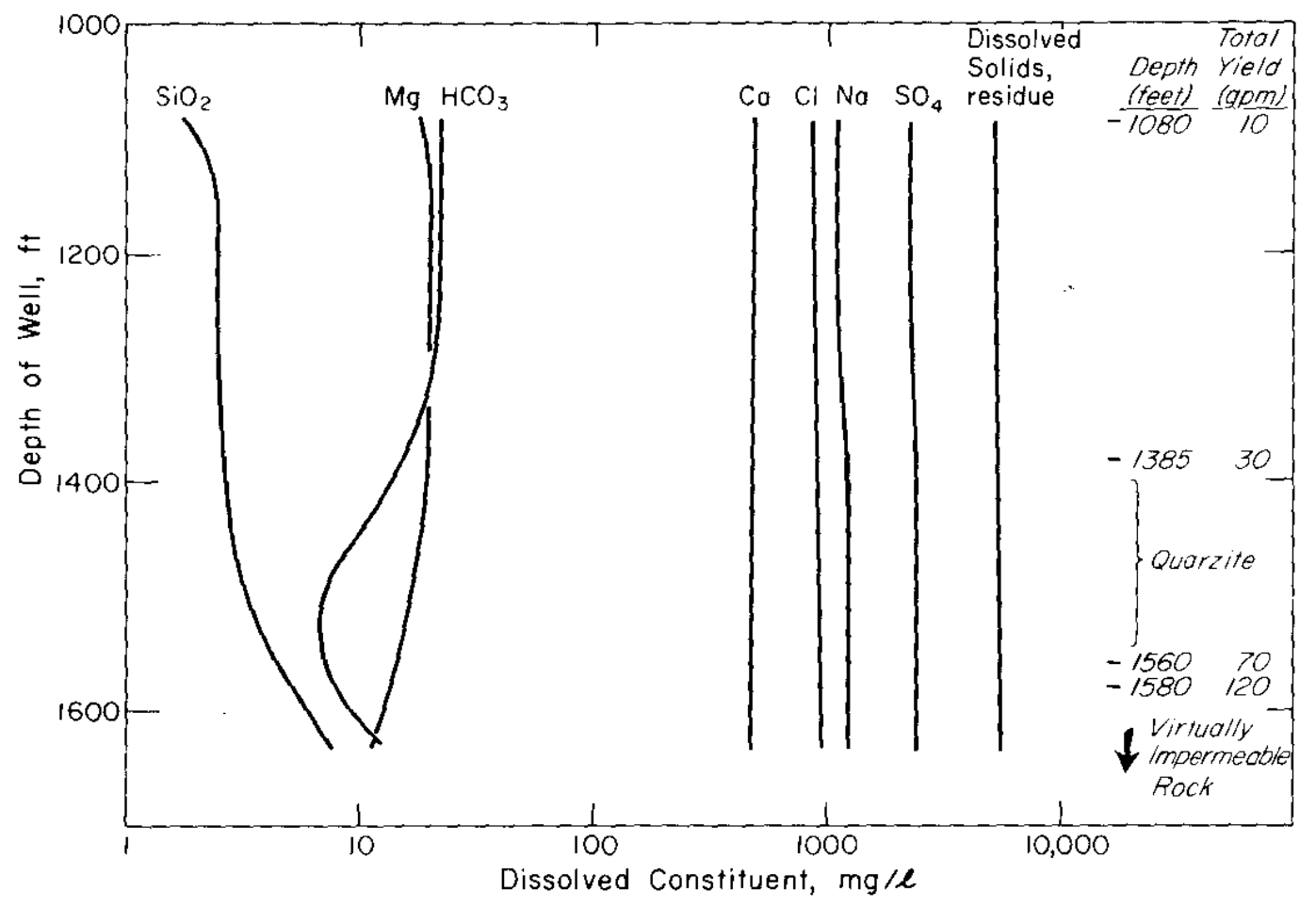

FIGURE 4. Changes in Water Chemistry with Depth in Well DRB 8 
different, there should have been a noticeable variation in the chemistry of the various samples. The principal points of inflow to the well and their yields are shown in Figure 5. No significant change occurred in calcium, sodium, chloride, sulfate, or dissolved solids. Silica increased after a section of quartzite was penetrated, and magnesium decreased slightly. Bicarbonate decreased in the quartzite section, but increased again after the schist was again penetrated.

The drilling fluid in DRB 8 was changed from compressed air to water when the well reached a depth of 1631 feet because the rapid recovery of the water level made adding drill rods difficult. In the last 6 days of drilling, between 16,000 and $47,000 \mathrm{gallons}$ of fresh water were injected into the rock fractures. Upon completion of the we1l, 144,000 gallons of water were pumped from the wel1, which is between 3 and 9 times the volume injected depending on which estimate is used. Dispersion of the drilling water entering the fractures did not permit the return of the dissolved constituents to their pre-injection values, even after the removal of 3 to 9 times the volume of water that was injected. A period of one year elapsed before pumping was resumed, when about 378,000 additional gallons were removed. During this water removal, the level of dissolved constituents continued to increase until stabilizing during the last hundred thousand gallons (Figure 6). Thus, the final sample from DRB 8 is probably representative of native water from the crystalline metamorphic rock.

We11 DRB 9 was drilled near the margin of the Triassic basin (Figure 2) using air as a circulating fluid. After passing through 1034 feet of Coastal Plain sediments, the well penetrated 1593 feet of Triassic red beds. The yield of water from the Triassic rocks was about $0.14 \mathrm{gpm}$. At a depth of 2626 feet, the interface between the Triassic rock and the crystalline metamorphic rock was penetrated, and the water yield increased to $4 \mathrm{gpm}$. The well was stopped at a depth of 2694 feet. Analyses of water samples taken at this depth (Table 3), are similar to those taken in other areas of crystalline rock and quite dissimilar to that of the water from the Triassic rock above, especially in chloride and sulfate content.

After completion of the drilling, the well was filled with fresh water for 14 hours to make certain geophysical logs; then the water was pumped from the hole. The analysis of a sample from DRB 9 on July 18, 1969 (Table 3), shows that virtually all of the fresh water was removed from the hole. In the spring of 1970, however, water injection tests were made on this well so that native water is no longer present in the hole (as of March 1976).

In 1968 and again in 1973, weIl P4R still showed the effects of the fresh water that was used to drill the well in 1962. This well was completely plugged with concrete in July 1973. 


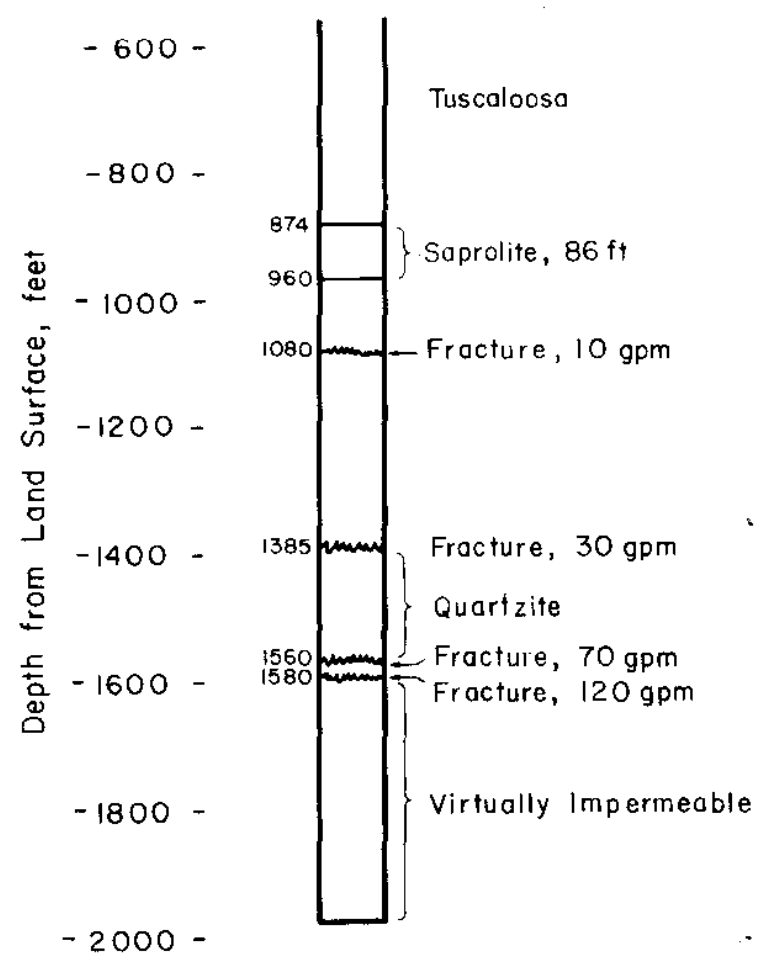

FIGURE 5. Water-Transmitting Fractures in Well DRB 8 


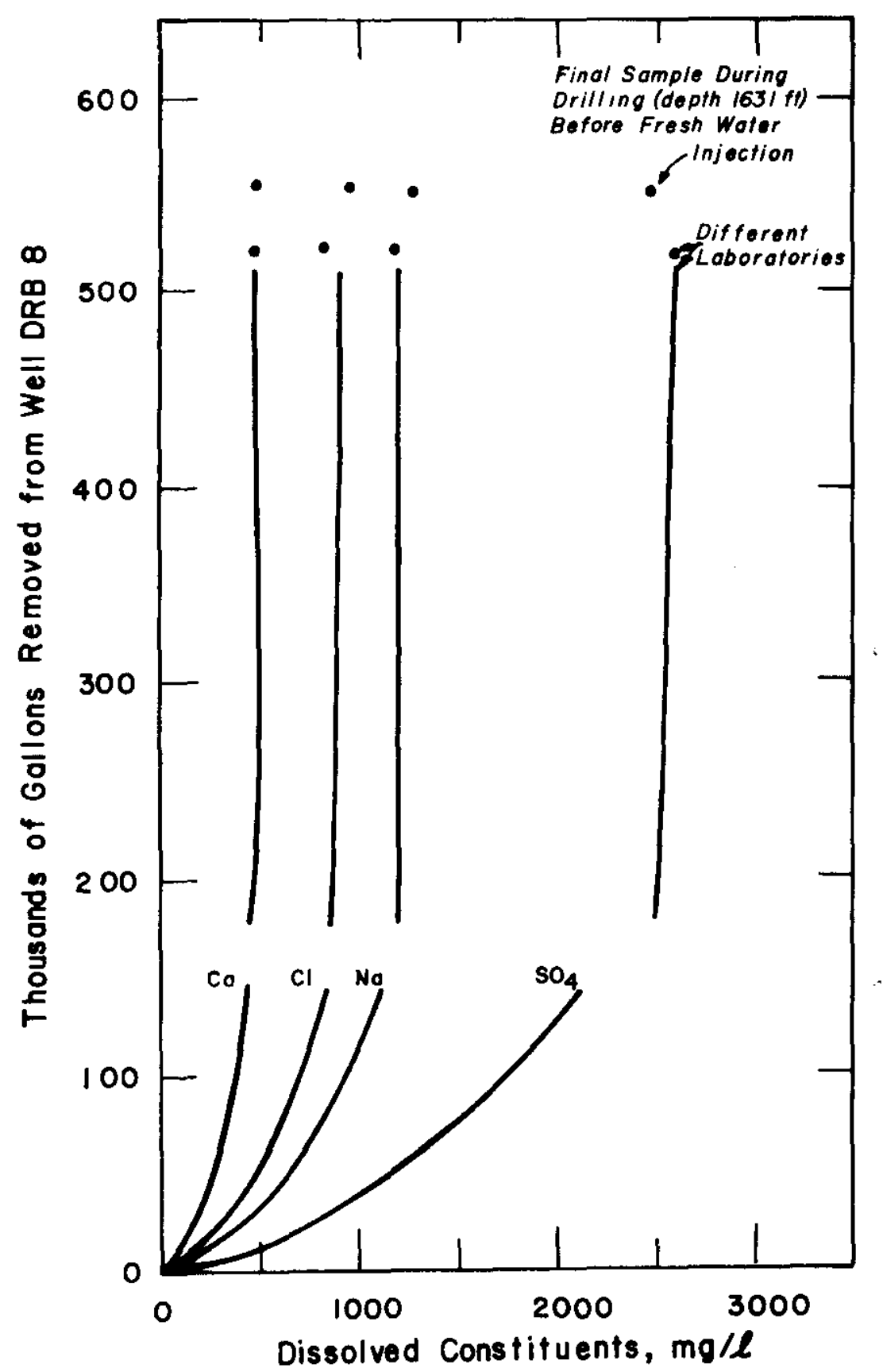

FIGURE 6. Changes in Water Chemistry of Well DRB 8 with Removal of Injected Fresh Water 
Well P6R was drilled with air, and no foreign water has ever been injected into the well. However, the effects of different sampling methods are shown by the changes in $\mathrm{pH}$ and in the bicarbonate, carbonate, and hydroxide content.

We11 P7R was drilled using compressed air as a circulating fluid. The sample of December 6, 1967, is native water. However, on December 13, 1967, an artificial hydrofracture was made in the well, and although most of the fracturing fluid was removed, the sample of January 29, 1968, shows by its sodium, potassium, and chloride contents that some fracturing fluid remained in the hole.

Well P8R was drilled using compressed air as a circulating fluid, and the sample of December 1, 1967, was taken when drilling was finished. Hydraulic packers have been placed in the hole on several occasions, and this necessitates the introduction of a small amount of fresh water, but sufficient water has been pumped from the well to remove any traces of this fresh water. All samples from this well for which analyses are reported are valid native water.

Both Wells P9R and PllR were drilled with air, and the samples for which analyses are reported are valid native water.

\section{WATER FROM TRIASSIC ROCK}

The isotopic ratios, dissolved gases, and dissolved solids were analyzed in water samples from Triassic rock (Table 4). Wells DRB 9 and DRB 10 were drilled using air as a drilling fluid, and the analyses should be representative of native water. We11 P12R was drilled using water as a drilling fluid; however, when the well was completed, all of the water was pumped from the hole, and native water was allowed to seep in before the sample was taken. The analysis should therefore be representative of the Triassic water at that depth and location.

Wel1 DRB 11 was continuously cored and was deviated from the vertical in order to explore a fault inferred from geophysical exploration. These procedures required that water be used as a circulating fluid. Thus, no water samples were obtained while the hole was being drilled. After the hole was completed and geophysical logs were made, an attempt to flush the drilling water out of the hole was made. Caving problems during drilling prevented pumping out all the drilling water, as was done in $P 12 R$, for fear of collapsing the hole. Much of the well inflow came from a depth of about 2340 feet. It was less certain, but suspected, that some inflow came from depths between 3000 and 3100 feet. 
Because of the extremely small yield of the well (0.07 gpm), any type of flushing operation would require a long time. To flush the hole, the drill rod was placed at the bottom of the well, and the annulus between the well casing and the drill pipe was blocked so that water could only flow from the drill pipe. The flow (from a depth of 2340 feet) descended to the bottom of the well and then ascended in the drill pipe. This process was continued for a calculated length of time so that after the drill pipe was removed the native water should have occupied the lower part of the well from a depth of 2850 feet to the bottom. The well was then permitted to flow, and after 14 to 18 days of flow, the electrical conductivity of the discharge water abruptly increased from 4500 to 19,600 micromhos (Table 12) indicating that the drilling water had been displaced. If the flow had come from between 3000 and 3100 feet, then all of the drilling water in the well bore would have been displaced; however, if water entered the well only at 2340 feet, the drilling water would have remained in the well bore between 2340 and 2850 feet. The sample collected by a cable sampler on April 23, 1973, from 2700 feet indicated the water entered the well at 2340 feet. Yet the geophysical $\log$ of the self-potential (Figure 7) made before the flushing operation indicated that the water at the bottom of DRB 11 was fresher than the water in the depth interval between 2100 and 2350 feet. Thus the sample collected on April 23, 1973, from a depth of 2700 feet may be indicative of native water in this part of the hole.

We11 P5R was drilled using water as a drilling fluid, and two bottom hole water samples (one collected in January 1968, and one in April 1973) showed that this water still resided in the hole. 


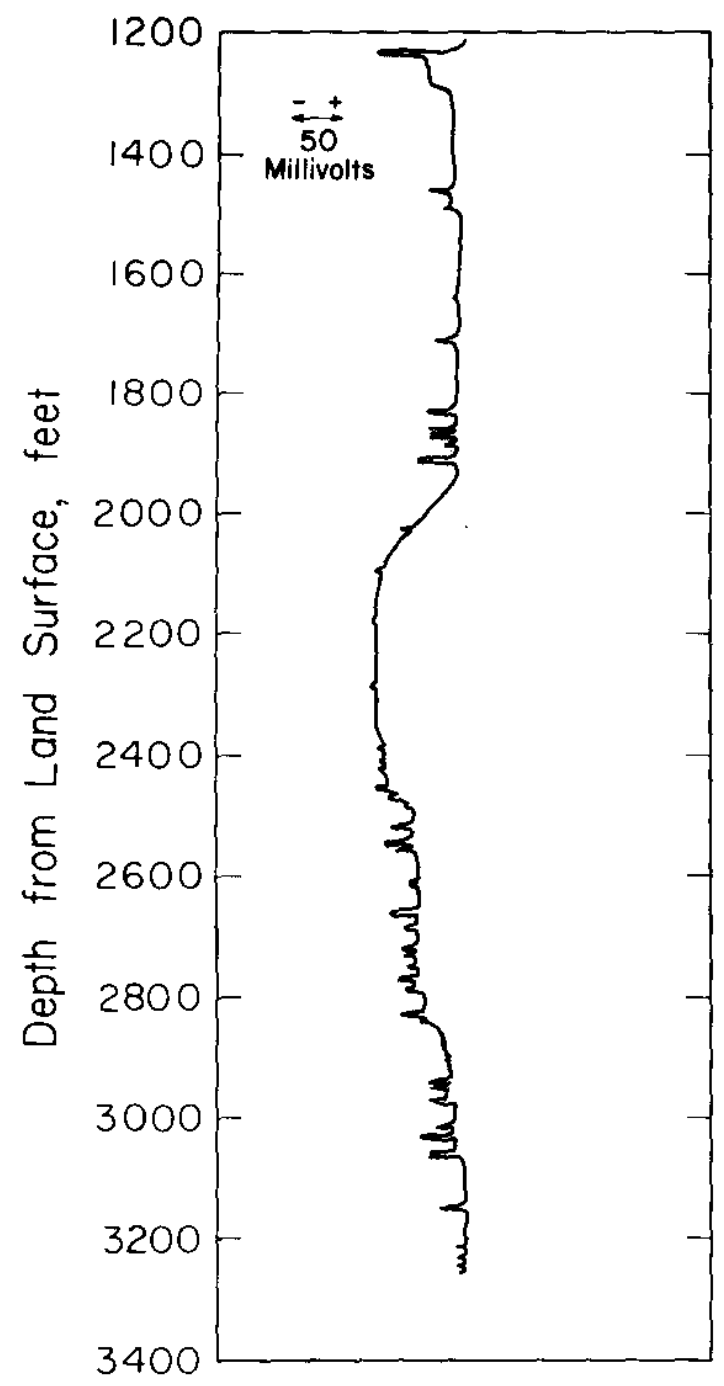

FIGURE 7. Geophysical Log of the Self-Potential of We17 DRB 11 


\section{SURFACE WATER AND COASTAL PLAIN SEDIMENTS}

Chemical analyses of surface water sources (Table 1) indicate that the total dissolved solids are quite variable, ranging from about 10 to about 100 milligrams per liter (mg/1). Much of this difference is caused by the variability of magnesium, calcium, and bicarbonate ion concentrations, which are usually more influenced by ambient surface conditions than others. Generally, sodium, chloride, and sulfate concentrations are more constant in value.

The individual geologic formations underlying SRP and their characteristics are given in Table 13. A description of the Eocene formation waters is given by Siple, ${ }^{4}$ and the analyses are presented in Table 9. Only one well for which periodic samples were taken (Table 2) was in the Eocene sediments (McBean Formation). The remaining five wells in Table 2 are in the Tuscaloosa formation of Late Cretaceous age. Water from this prolific water-bearing bed, which supplies water to most large wells at SRP, is very low in dissolved solids, generally averaging between 10 and $40 \mathrm{mg} / 1$.

In addition to being low in dissolved solids, the water from the Tuscaloosa formation is acidic $(\mathrm{pH} \approx 5.5)$, and some of it is saturated with dissolved oxygen. This makes the water very aggressive in its attack on metallic surfaces.

The high dissolved oxygen content of some water from the Tuscaloosa formation is correlative with a low sulfate content. A dissolved oxygen content of 8 or $9 \mathrm{mg} / 1$ indicates a sulfate content of less than $2 \mathrm{mg} / \mathrm{l}$, whereas analyses that show zero dissolved oxygen have a sulfate content of about $13 \mathrm{mg} / 1$. Well 67U (Table 2) was drilled to a depth of 800 feet, near the bottom of the Tuscaloosa formation, in an effort to find a stratum at this locality that was free of dissolved oxygen. The well was finally screened between 630 and 725 feet, but the water is nearly saturated with dissolved oxygen. Thus, the dissolved oxygen does not vary vertically; however, it varies laterally, as Wel1 43H has zero dissolved oxygen. Figure 8 shows the distribution of dissolved oxygen in water from SRP wells. (Not all of the analyses shown are presented in the tables of this report.) 


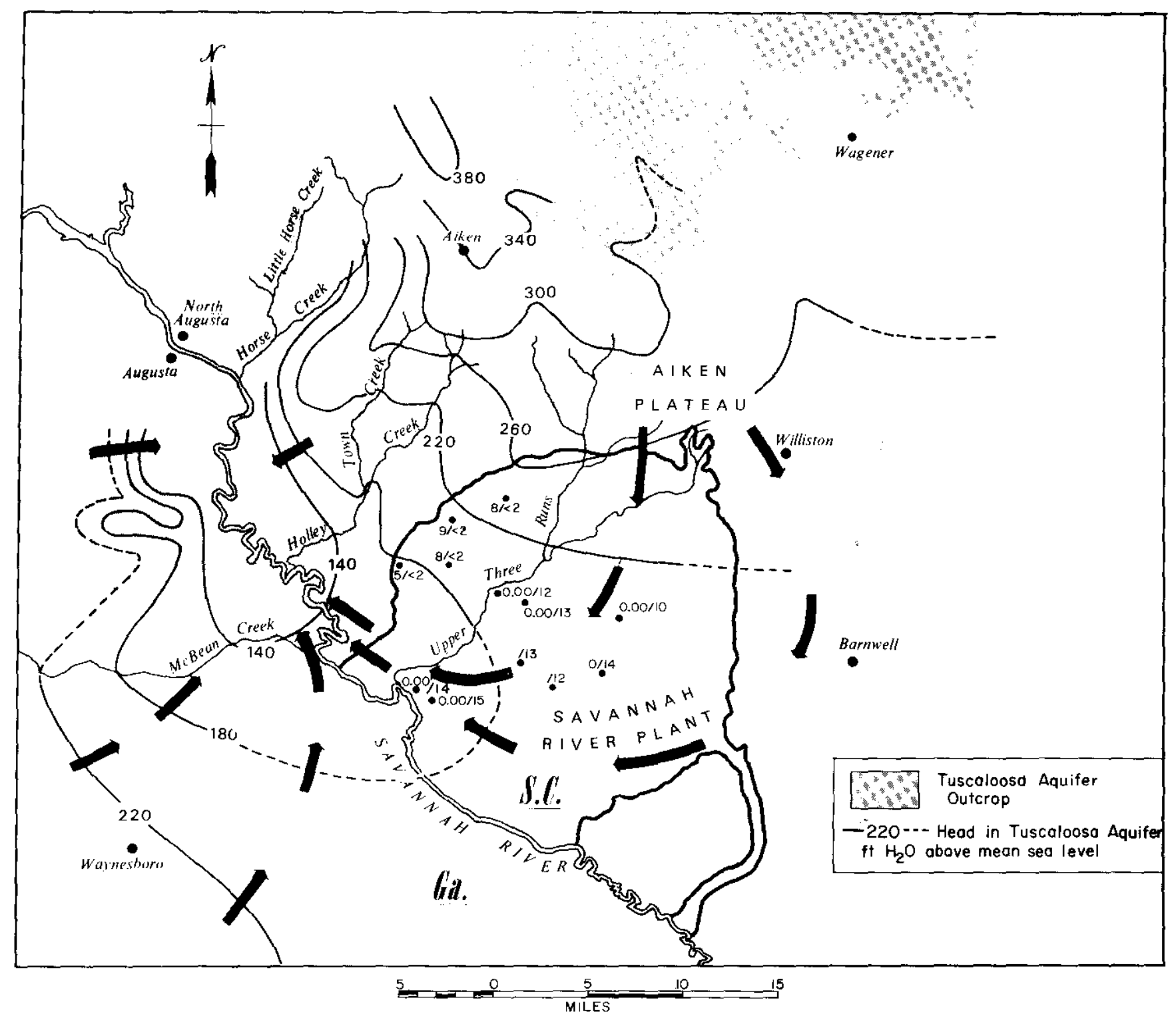

FIGURE 8. Map Showing Dissolved 0xygen and Sulfate Ion Concentrations in waters from the Coastal Plain Sediments. Numerator is dissolved oxygen concentration, ppm. Denominator is dissolved sulfate ion concentration, ppm. Arrows indicate flow paths in the aquifer. 
Sulfide minerals (pyrite, marcasite) exist in the Ellenton formation, and the map pattern may indicate a slowly advancing sulfide oxidation front. Water from wells behind this front are saturated with oxygen, as all sulfide minerals have already been oxidized. Oxygen dissolved in water in advance of this front is combining with the sulfide minerals and enriching the sulfate content of the water. Sulfide minerals are not common in the Tuscaloosa aquifer, but there may be some that are not readily identifiable.

\section{CRYSTALLINE METAMORPHIC ROCK}

\section{Hydrologic History}

The change in water chemistry from the lower part of the Coasta1 Plain sediments to the top of the crystalline rock is abrupt and occurs within the saprolite. Water from the crystalline metamorphic rock is characterized by a much higher dissolved solids content $(6000$ versus $30 \mathrm{mg} / 1)$ and high calcium $(500 \mathrm{mg} / 1)$, sodium (1400 mg/1), sulfate (2300 $\mathrm{mg} / 1)$, and chloride (1400 mg/l) concentrations. The bicarbonate content is extremely low in samples of water from the crystalline rock ( $16 \mathrm{mg} / 1)$.

The origin of the water found in the crystalline metamorphic rock is related to the age of the water and is a question of great interest in relation to waste storage in bedrock. The water in the crystalline metamorphic rock now enters the rock through the soil zone in or near the piedmont province (Figure 9) and moves very slowly toward a discharge area in the Savannah River northwest of SRP. Information on the hydraulic head in the groundwater system (Figure 9) provides support for this view of the present ground-water circulation system. The dilemma concerning the origin of the water in the crystalline rock is whether the water now found in the crystalline metamorphic rock is simply a product of the operation of this same system, or whether it is relic sea water. In the former case, the geologic history of the area would provide no specific indicators of the age of the water. In the latter case, the last inundation of the sea would provide information on the age of the water. Irrespective of its origin, the water now found is neither rainwater nor sea water, but has been greatly modified by the rock environment in which it has been for a very long time. If the original water were rain, the net action of the water is dissolution of rock material; if the original water were sea water, the net action is one of flushing and dilution, as well as modification of the ionic ratios of the constituents. If the origin of the rock water were rain, the hydraulic system is easy to visualize, as it would be the same as that which exists now. If the present water were originally part relic sea water, it is more difficult to visualize a hydraulic system where the sea water would enter the crystalline 


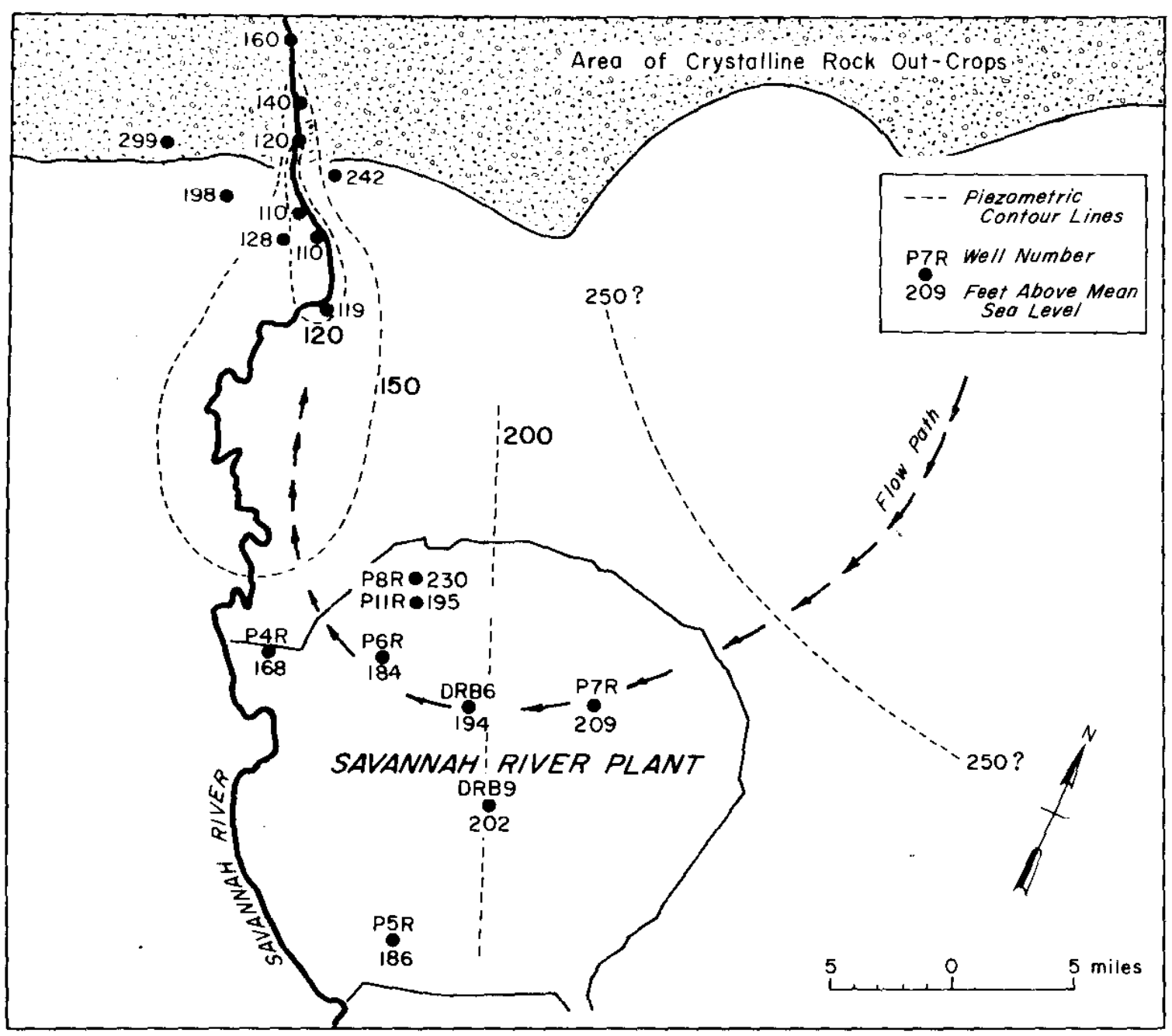

FIGURE 9. Piezometric Map of Water in Crystalline Metamorphic Rock and Inferred Flow Paths 
rock, because differences in water-level elevation, which are the cause of most ground water circulation on land, would not exist if the entire area had been covered by the sea.

The geologic-hydrologic history of the SRP area is presented in Table 14, and indicates that after the formation of the crystalline metamorphic rock in the Permian Period about 260 million years ago, there followed a long period of 216 million years of emergent conditions. At the end of this period, the water in the crystalline rock must have been modified rain water. The sea alternately covered the area and receded for the next 19 million years. It is during this period that sea water could conceivably have entered the crystalline rock during periods when sea level rose slowly, backflushing the rock; that is, sea water entered what is now the discharge end of the aquifer system and progressively reduced the volume of the aquifer available for fresh water circulation. In the last 25 million years, emergent conditions have predominated, and this should have been sufficient to flush whatever sea water had entered from the previous period

of inundation. Thus, if relic sea water is in the crystalline rock, it can only be pleistocene in age (back to 1 million years ago). During this period, the sea never covered the recharge area for the crystalline rock (Figure 9), but on possibly four occasions, an arm of the sea invaded the Savannah River valley coming to a lower level each time. The helium in the rock water, however, indicates that its average age is older than these last incursions of the sea. Thus, on the basis of geologic and hydrologic history, a case cannot be made for considering the water from the crystalline metamorphic rock as relic sea water.

Dissolved Solids

The principal argument that leads to consideration of relic sea water is the chloride content in the water from the crystalline metamorphic rock (Table 3) in the absence of apparent chloridebearing minerals in the rock itself. However, chemical analyses of the unweathered rock (Table 5) showed 0.02 percent or 200 milligrams of chloride per kilogram of rock. Without regard to the chemical kinetics of the system, this concentration appears to be sufficient to account for the chloride content of the water. For example, if all of the chloride in a kilogram of rock were dissolved by the water existing in that kilogram of rock at a porosity of 0.2 percent, the concentration in the water would be 100,000 parts per million, more than 60 times the amount found.

To provide more information on whether dissolution of minerals in the crystalline rock by rain water could develop the chemical characteristics of the water now found in the crystalline metamorphic rock, distilled water was placed in contact with ground 
rock for one week (Table 15). The resulting fluid was high in calcium and sulfate (as is the water from the rock), but it was low in sodium and chloride. Such results may indicate an external source of sodium chloride; however, this single shortterm experiment without additional consideration of the chemical environment in the crystalline metamorphic rock is not conclusive.

Additional information on an external source for some chemical constituents is provided by sulfur isotope ratios in the sulfate in the water and the sulfide minerals in the rock (Table 8). The range of the ${ }^{34} \mathrm{~S} /{ }^{32} \mathrm{~S}$ ratio (expressed in parts per thous and variation from the standard Canyon Diablo Troilite) in the sulfide minerals in the rock is +2.1 to +5.7 , whereas the range of ${ }^{34} \mathrm{~S} /{ }^{32} \mathrm{~S}$ ratio in the sulfate in water from the rock is +10.8 to +24.7 . Thus, from this information, it appears that the sulfate in the water is from an external source.

The ${ }^{34} \mathrm{~S} /{ }^{32} \mathrm{~S}$ ratio of water from the Coastal Plain formations as reported is very erratic, ranging from -22 to +23 . This sulfate is necessarily either biogenic or dissolved from the sulfide minerals in the sediments and could be the source of the ${ }^{34} \mathrm{~S} /{ }^{32} \mathrm{~S}$ ratio in the crystalline rock. No analysis was made on the sulfide minerals in the sediments, which are present principally in the Ellenton formation. Thus, although ${ }^{3{ }^{34}} \mathrm{~S} /{ }^{32} \mathrm{~S}$ analyses show that the source of the sulfate in the water from the crystalline metamorphic rock is not simply a dissolution of sulfide minerals in the rock, it does not show conclusively that it is relic sea water.

The determination of ratios of prevalent ions is a common method applied in deciphering the origin of water, and it is particularly useful if a certain water is suspected to be a mixture of two other waters. For this purpose, the ionic concentration in $\mathrm{mg} / \mathrm{l}$ is converted to chemical equivalents, or mg (equiv)/1. For the bedrock water at SRP, the dominant cations are calcium and sodium, and the dominant anions are sulfate and chloride. Although magnesium, potassium, and bicarbonate are present, their amounts are negligible compared to the four dominant $i$ ons, and in the subsequent considerations they will be neglected. The same treatment could not be used for the waters from the Coastal Plain sediments. Figure 10 shows the percent of calcium in the sum of calcium and sodium values plotted against the percent of sulfate in the sum of sulfate and chloride values for each of the most representative and reliable analyses of bedrock water. Because only two ions are involved on each coordinate, the graph also shows the percent sodium and the percent chloride. Such a plot gives no indication of concentration of the various ions; thus, two waters may show the same ionic percentages even though one has a total dissolved solids of 30 $\mathrm{mg} / 1$ whereas the other has $30,000 \mathrm{mg} / 1$. Water that is a mixture of two other waters would plot on a straight line connecting the two mixing waters. 


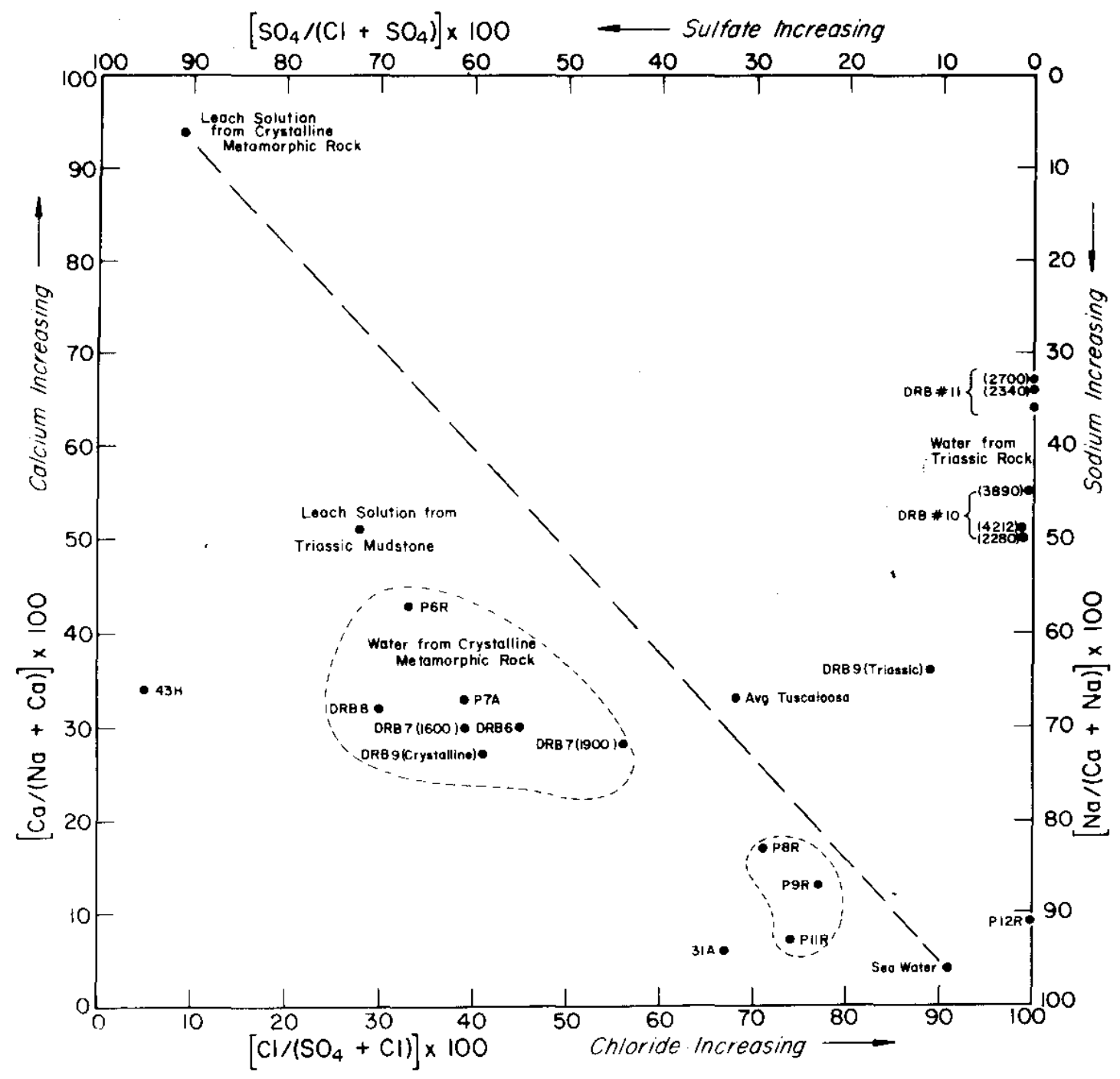

FIGURE 10. Ionic Ratios of Selected Ground Water Samples at SRP (Numbers in parentheses are sampling depths in feet below ground surface) 
Water from the crystalline metamorphic rock (Figure 10) appears clustered around $30 \%$ calcium $(70 \%$ sodium) and $60 \%$ sulfate ( $40 \%$ chloride). These samples were collected from a large region: Well P6R is 5 miles west of DRB 6 , whereas Well P7R is 4-1/2 miles northeast of DRB 6 , and Well DRB 9 is $3-1 / 2$ miles southeast of DRB 6 and beneath Triassic rock. Yet, the analyses of water from all of these wells are in the same region of the graph (Figure 10).

The ionic ratios of this cluster of bedrock waters are quite different from the ionic ratios that developed in a leach solution of distilled deionized water in the presence of finely ground crystalline metamorphic rock (Table 15). For reference, the ionic ratios for the same constituents of modern sea water ${ }^{5}$ are plotted in Figure 10. The same ratios are plotted for average Tuscaloosa formation water (Table 9) and two specific Tuscaloosa formation water analyses (Wells $43 \mathrm{H}$ and 31A, Table 2). The wide scatter of these three points for water from the Tuscaloosa formation are caused by: (1) ions other than those plotted cannot be neglected for the Coastal Plain waters; (2) the low ionic concentrations of the Coastal Plain waters approach the analytical limits for some of the ions; and (3) the control that oxidation of sulfide has on the sulfate ratio (Well $31 \mathrm{~A}: \mathrm{O}_{2}=9.9 \mathrm{mg} / 1$, $\mathrm{SO}_{4}=2.3 \mathrm{mg} / 1$; Well $\left.43 \mathrm{H}: \mathrm{O}_{2}=0.0 \mathrm{mg} / 1, \mathrm{SO}_{4}=14.3 \mathrm{mg} / 1\right)$.

Based on Figure 10, it would appear that the water from the crystalline rock is not solely derived from the simple leaching of the minerals in the crystalline rock, nor is it sea water. However, it does appear conceivable that it may be a mixture of the two, although other chemical reactions have apparently taken place. For example, the precipitation of calcium carbonate, which does exist as vein fillings in the rock, would tend to drop the cluster of bedrock waters below the straight line connecting the leach water and sea water, possibly accounting for its present position on the graph. To confirm such a hypothesis would require a great deal more work with leach solutions and their reaction with sea water. This work was not completed when the bedrock investigation was postponed. The ionic ratios of Tuscaloosa formation water (Figure 10) indicate the crystalline rock water is apparently not a simple mixture of sea water being diluted (flushed) with Tuscaloosa water. This conclusion is expected because the explanation completely neglects the chemical environment of the crystalline rock which must contribute to the chemical characteristics of the water.

The cluster of analyses of water from We11 P8R on Figure 10 shows a quite different type of water than that from the typical crystalline metamorphic rock. Well P8R has a hydraulic head that is higher than is consistent with the piezometric map derived from head measurements in other wells (Figure 9). Water from Well P8R is much lower in total dissolved solids $(500 \mathrm{mg} / 1)$ than 
most we $11 \mathrm{~s}$ in crystalline rock $(6000 \mathrm{mg} / 1)$. The hydraulic head on this we 11 is 23 feet higher than the head in an adjacent Tuscaloosa well, so simple leakage from poor well construction or a break in the saprolite is precluded. A reflection seismic traverse indicated a fault about 200 feet southeast of Well P8R. In an effort to provide more information on the anomalous character of Well P8R, Wells P9R and P11R were drilled about 4000 feet east of We1l P8R to determine if the head and quality of water were similar to those of Well P8R or to those of most other wells in crystalline metamorphic rock. As shown on Figure 9, the head is consistent with those of the other crystalline rock wells. The total dissolved solids from Wells $P 9 R$ and PllR are consistent with those of other crystalline rock piezometers (from Table 3: $\mathrm{P} 9 \mathrm{R}=3400 \mathrm{mg} / 1, \mathrm{PI} \mathrm{R}=3500 \mathrm{mg} / 1, \mathrm{P} 6 \mathrm{R}=3000 \mathrm{mg} / 1$, and $\mathrm{P} 7 \mathrm{R}=$ $5000 \mathrm{mg} / 1$ ), although water from the crystalline rock in the central part of SRP is somewhat higher $(\mathrm{DRB} 6=6000 \mathrm{mg} / 1$, DRB $7=$ $8000 \mathrm{mg} / 1$, and DRB $8=5500 \mathrm{mg} / 1$. However, in terms of the ionic ratios, the waters from Wells $P 9 R$ and $P 11 R$ more closely resemble that from well P8R (Figure 10). It is also of interest that water from nearby Tuscaloosa Well 3lA has similar ionic ratios. However, the plot of ionic ratios (Figure 10) confirms the conclusion (based on the head relationships) that the water at Well P8R is not a simple mixture of Tuscaloosa water and water from crystalline rock. The origin of this water is not determinable from present information.

\section{Isotopic Ratios}

The isotopic ratios of deuterium to hydrogen and oxygen-18 to oxygen-16 can sometimes be used to show the origin and (under special circumstances) the age of the water. Both isotopic ratios are reported in parts per thousand departure from standard mean ocean water (SMOW). ${ }^{2}$ The isotopic analyses of deuterium and oxygen-18 for water samples from the SRP vicinity are plotted on Figure 11. For worldwide precipitation, the relationship be tween deuterium and oxygen-18 is expressed ${ }^{1}$ by $\delta D=8 \delta^{18} 0+10$, where $\delta=\left[\left(R / R^{\prime}\right)-1\right] \times 1000, R$ is the isotopic ratio of either deuterium to hydrogen or ${ }^{18} 0$ to ${ }^{16} 0$ in the sample, and $R^{\prime}$ is the same ratio for SMOW. Thus, the world precipitation line has a slope of 8 . Craig also found that when water was subjected to evaporation, $\delta D=5 \delta^{18} 0$; i.e., the water departed from the World Precipitation. Line with a slope of 8 and onto a line that had a slope of 5 .

Samples from the Savannah River lie on the World Precipitation Line (Figure 11) except for one sample (fal1, 1971) that falls on an evaporation line with a slope of 5 . Samples from Lower Three Runs Creek appear to correlate with an evaporation line except for one sample (fall, 1971). Both of these streams have large dammed 


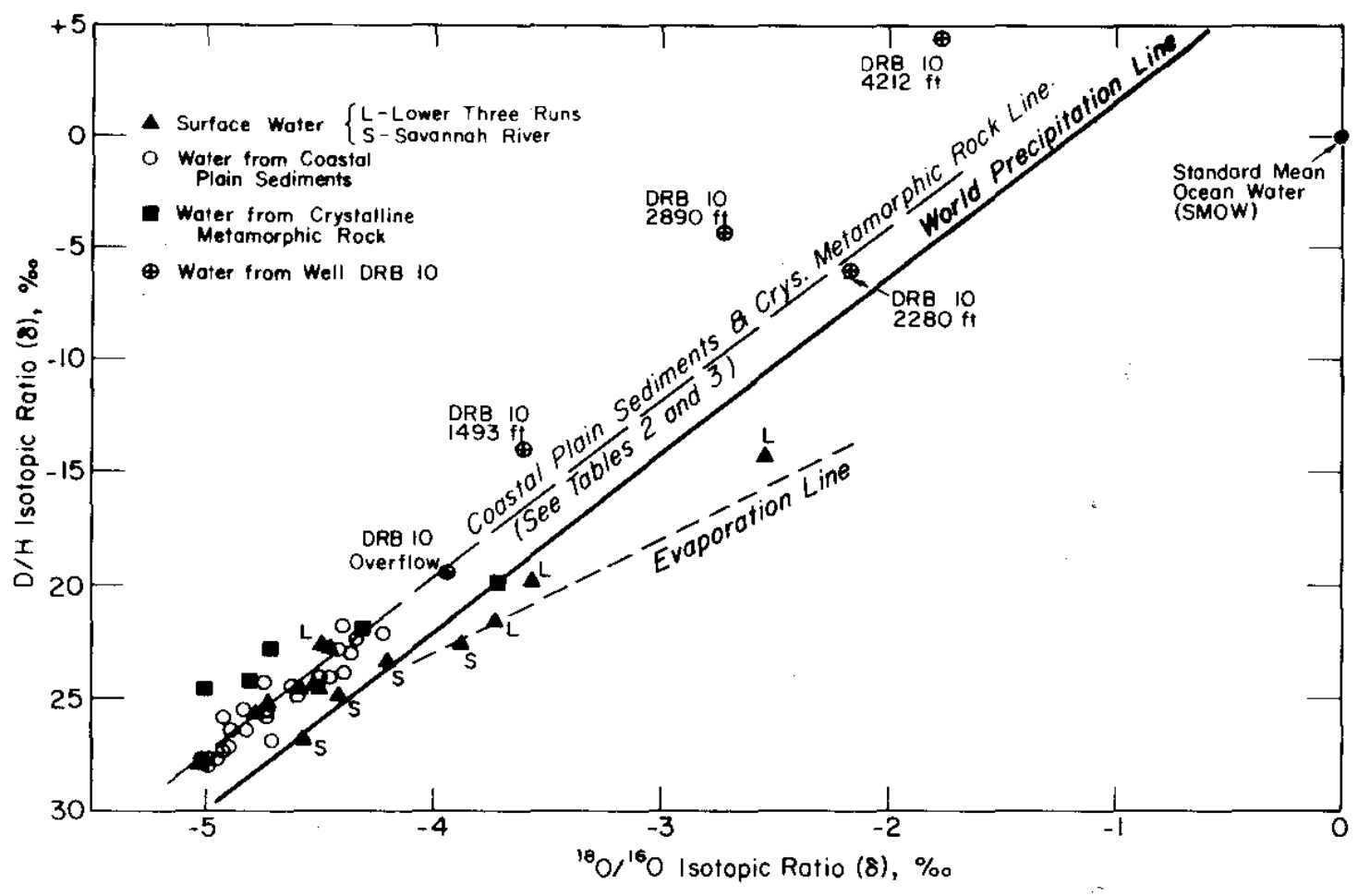

FIGURE 17. Isotopic Ratios for Deuterium and Oxygen-18 for Water Samples from Vicinity of SRP 
reservoirs on them, thus providing ample opportunity for evaporation. The reservoir on Lower Three Runs Creek receives heated reactor cooling water that probably enhances the evaporation from the reservoir.

Ground water from wells in the Coastal Plain sediments appears to correlate along a line that is parallel to the World Precipitation Line, but displaced from it by about 0.3 parts per thousand ${ }^{13} 0$. Analyses of water from Hollow Creek and Upper Three Runs Creek also correlate along this same line, which is not surprising because much of the flow of these creeks comes from effluent ground water. The source of the stream water is water from the Coastal Plain sediments; the source of the water in the Coastal Plain sediments is precipitation on the interstream areas. The ${ }^{18} 0$ shift in the ground water from the precipitation line may be due to selective precipitation or solution of oxygen-containing minerals in the ground or to organic processes in the soil zone.

Isotopic analyses of water samples from the crystalline metamorphic rock plot nearly on the same line as similar analyses of water from the Coastal plain sediments. This may mean that the water in the crystalline metamorphic rock originated in the sediments. The isotopic analyses also indicate that the water from crystalline metamorphic rock is not a simple mixture of sea water (SMOW, Figure 11) and precipitation (World Precipitation Line, Figure 11).

\section{Radioisotope Dating}

Duplicate analyses of native rock water pumped from Well DRB 6 on September 17, 1964, showed a tritium content of 3 tritium units with a possible error of 150 percent, and 0 tritium units with a possible exror of 14 percent. Thus, this water has no tritium; however, this indicates only that it is older than about 40 years.

Because the range on radiocarbon dating is between 3000 and 50,000 years, much effort was directed toward obtaining radiocarbon dates. As the water from the crystalline rock contains only about 16 ppm bicarbonate, collection was laborious, and special precautions against contamination were taken.

The first system for collecting carbon was one consisting of several ion exchange resins in series as described by Crosby and Chatters. ${ }^{6}$ The system consisted of pumping a predetermined amount of well water (1270 liters) through 50 liters of a weakly basic anion exchange resin (to remove the sulfate and chloride ions) and then through 0.3 liters of a strongly basic anion exchange resin to remove the bicarbonate ions. The entire system 
was kept under positive nitrogen pressure. The average rate of throughput was 575 milliliters per minute. In addition, samples of water were collected before entering the system, after the first resin container, and after the second resin container.

No carbonate ion was extracted with the second ion exchange resin, and analysis of the water samples showed that the resins had practically no effect on the water that passed through them. The difficulty was in the $\mathrm{pH}$ of the original water, which was about 8 . For the basic ion exchange resins to function, the well water should have been acidic.

Although an alternative design using ion exchange resins was developed, it was realized that the results obtained by the ion exchange method were suspect unless they could be checked by a more accepted method of carbon collection. The ion exchange method for carbon collection was therefore abandoned in favor of the more accepted gas evolution technique. ${ }^{7}$ In this method, the water is acidified to convert the dissolved bicarbonate to carbon dioxide, which is then passed through a strontium chloride trap to precipitate the carbon as strontium carbonate.

In the system used here, a 55-gallon stainless steel drum was connected directly to the well which contained a submersible pump. After purging with well water and nitrogen gas, the drum was filled with well water. About $200 \mathrm{ml}$ of sulfuric acid was added to lower the $\mathrm{pH}$ of the water and allow the bicarbonate to evolve as carbon dioxide gas. Nitrogen from tanks was passed through a carbon dioxide trap, and then bubbled through the water to sweep the carbon dioxide from the drum. The gas was passed through a drier, then bubbled through a trap containing an ammonium hydroxide-strontium chloride solution to precipitate strontium carbonate. After stripping the carbon dioxide from the water, the drum was emptied under a nitrogen purge and refilled from the pumping well by lines that had only contained well water in the interim period. The well was pumped continuously through a valved bypass system when the drum was not being filled. Thus, no air was ever allowed to come in contact with the water.

Replicate samples were obtained from four wells, namely, DRB 6, DRB 8, P6R, and P8R. The carbon collection efficiency of these samples was low and variable, ranging from about 10 to 45 percent. The carbon-14 content also varied between replicate samples from the same well. In addition, the difference between

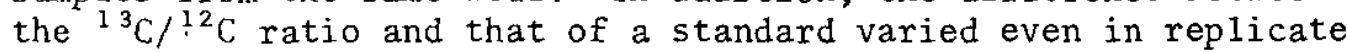
samples. Thus, not only was isotope fractionation taking place during collection, but also carbon contamination was being introduced at some stage in either the materials preparation, sample collection, or sample analysis phase of the operation. Therefore,

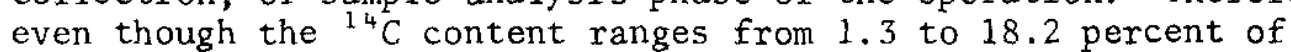
modern, the values are probably spurious and caused by contamination. 
The value of the difference of the ${ }^{13} \mathrm{C} /{ }^{12} \mathrm{C}$ ratio from a standard is $-15 \pm 2$ parts per thousand, which is common in ground waters. The value is about -25 in 1 and plants, and is nil in marine limestone. Thus, the carbon in the water from the crystalline rock could be a mixture of dissolved carbon dioxide from the soil-air interface and from dissolved rock carbonate. However, many other natural processes could work to alter the ratio. In addition, carbon fractionation was apparently occurring during the sample collection. Thus, conclusions cannot be drawn from the carbon analyses about the origin or the age of the water found in crystalline rock.

The age of the water, of course, is not the same as the age of the rock. However, knowing the age of the rock is helpful in interpreting the helium data. A potassium-argon date for the last heating of the rock to $300^{\circ} \mathrm{C}$ was determined for two samples by two different commercial laboratories. The first sample was from a depth of either 1665 feet or 1845 feet in Well DRB 7 . The age was 258 million years \pm 3 million years, the Permian period according to most geologic time scales. The last metamorphism of this rock would therefore have occurred during the Appalachian mountain building period, which was Late Pennsylvanian and Permian in age. The second sample was from a depth of 1294 feet in Well DRB 8 and provided an age of 290 million years \pm 11 million years. This analysis was made on the biotite from a sample of schist and was made by a different laboratory than the first sample. This age is Late Pennsylvanian according to most geologic time scales but is still within the epoch included in the Appalachian mountain deformation period.

Gas Analyses and Helium Determined Age

In addition to the dissolved solids, the water from the crystalline rock contains sufficient dissolved gas to effervesce when brought to the surface. This gas contains 91 to 96 percent nitrogen by volume (Table 3). However, the most significant constituent is dissolved helium. From the quantity of helium collected and the uranium and thorium content of the rock, a residence time for the water in the rock can be calculated. The following is an example of this calculation: the helium generation rate from uranium is reported ${ }^{8}$ as $11.0 \times 10^{-5} \mathrm{~mm}^{3} /(\mathrm{g} \mathrm{U}-\mathrm{yr})$, and from thorium $3.1 \times 10^{-5} \mathrm{~mm}^{3} /(\mathrm{g}$ Th-yr $)$ at standard temperature and pressure. For the crystalline rock at SRP, the uranium content averages $1.5 \mathrm{ppm}$ and the thorium $8 \mathrm{ppm}$. The helium generation rate from uranium is: $1.5 \times 10^{-6} \mathrm{~g} \mathrm{U} / \mathrm{g}$ rock $\times 11 \times 10^{-8} \mathrm{cc}$ $\mathrm{He} /(\mathrm{g} \mathrm{U}-\mathrm{yr})$, or $16.5 \times 10^{-14} \mathrm{cc} \mathrm{He} /(\mathrm{g}$ rock-yr $)$. The helium generation rate from thorium is: $8 \times 10^{-6} \mathrm{~g}$ Th/g rock $\times 3.1 \times$ $10^{-8} \mathrm{cc} \mathrm{He} /(\mathrm{g} \mathrm{Th}-\mathrm{yr})=25 \times 10^{-14} \mathrm{cc} \mathrm{He} /(\mathrm{g}$ rock-yr $)$. For both uranium and thorium together, the generation rate is $41 \times 10^{-14}$ $\mathrm{cc} /(\mathrm{g}$ rock-yr $)$. 
Now consider one cubic meter of crystalline rock with an average fracture and non-fracture porosity of 0.2 percent. There are $2 \times 10^{3} \mathrm{cc}$ of water in one cubic meter of rock. In Well DRB 6 (see Table 16), for example, there is $0.6 \mathrm{cc}$ of gas per liter of water and 6 percent of the gas is helium. Therefore, the water from the rock contains $3.6 \times 10^{-2} \mathrm{cc}$ helium per liter of water, or $3.6 \times 10^{-5} \mathrm{cc}$ helium per cc of water, or $7.2 \times 10^{-2} \mathrm{cc}$ helium per cubic meter of rock. The average density of the crystalline rock is reported ${ }^{9}$ to be $178 \mathrm{lb} / \mathrm{cu} \mathrm{ft}$, or about $2.9 \times 10^{6} \mathrm{~g} / \mathrm{m}^{3}$, so the helium accumulated in the crystalline rock is:

$$
\frac{7.2 \times 10^{-2} \mathrm{cc}_{\mathrm{He}} / \mathrm{m}^{3}}{2.9 \times 10^{6} \mathrm{~g} / \mathrm{m}^{3}}=2.5 \times 10^{-8} \mathrm{cc}_{\mathrm{He}} / \mathrm{g} \text { rock }
$$

If the accumulated helium is divided by the generation rate from uranium and thorium given above, the result will be the minimum length of time necessary to accumulate the observed quantity of helium.

$$
\frac{2.5 \times 10^{-8} \mathrm{cc}_{\mathrm{He}} / \mathrm{g} \text { rock }}{41 \times 10^{-14} \mathrm{cc}_{\mathrm{He}} /(\mathrm{g} \text { rock-yr })} \approx 60,000 \text { yeàrs }
$$

In Table 16, there are wide differences in the amount of gas recovered and the percent of helium in the gas between Wells DRB 3, DRB 5, and DRB 6 on the one hand, and Wells DRB 2 and DRB 7 on the other. Wells DRB 2 and DRB 7 penetrate virtually impermeable rock, whereas Wells DRB 3, DRB 5, and DRB 6 each penetrate one or more sections of fractured rock. The condition of the rock may affect the concentration of helium in the gas, and the amount of gas dissolved in the water. However, these differences may better be explained by the methods of collection of the gas samples, which differed between the two groups of wells.

We11s DRB 3, DRB 5, and DRB 6 were pumped continuously, and a fraction of the water was passed through a water-filled plastic bottle inverted in a tub of water. As the gas evolved from the water passing through, it displaced the water in the bottle. At a pumping rate of $20.5 \mathrm{gpm}$ (DRB 6) the water leaves the rocks at a depth of about 1785 feet and takes about 2 hours to travel up the wel1 and pass through the sample bottle. Wells DRB 2 and DRB 7 would not yield water continuously at a rate sufficient to pump. These weils were therefore pumped intermittently, drawing the water level down to the pump suction (615 feet below surface) each time; whereupon they were left idle for periods that varied from one to eight days before being pumped again. During these idle periods, the dissolved gas and the helium had ample opportunity to come into equilibrium with their new temperature and 
pressure conditions. In DRB 2, for example, about four days elapsed between the time the water left the rock and the time that it passed through the sample bottle. The different methods and rates of obtaining the water from the various wells may explain some of the differences in helium concentration and in the amount of gas recovered. Gas recovery was not considered complete because of the short period of time required for the water to pass through the inverted bottle. In addition, all elements probably did not evolve in the true proportions in which they existed in the dissolved state.

To overcome these difficulties, equipment was developed to collect water samples in a pressurized flask and evolve the gas in the laboratory. The pressure was approximately equivalent to 900 feet of water. The analyses of two such collections from DRB 6 are shown in Table 17. This table also shows the values calculated for DRB 6 and DRB 7 by applying Henry's Law to the earlier data. The agreement of these calculated values for DRB 6 with the data from the pressurized sample collection bottles is considered good. The last column of Table 17 contains reference values for the amount of each gas dissolved in pure water in equilibrium with mean sea level air at $20^{\circ} \mathrm{C}$. When the analysis for the sample collected under pressure from Well DRB 6 and the method of age calculation given above are used, the residence time for water in contact with rock is 840,000 years. The length of flow path (Figure 9) from near the outcrop area through Well DRB 6 is inferred to be 32 miles. Assuming flow along this path constitutes residence time for the water, the velocity of the water is $20.2 \mathrm{ft} / \mathrm{yr}$.

Several assumptions involved in this calculation need explanation:

- The water contains 100 percent of the helium generated. This assumption cannot be true as some must reside in the rock where it was first generated. Table 7 shows helium analyses of the rock, and the uranium and thorium content of the same rock samples. A definite correlation exists between the uranium-thorium content and the helium content of the rock specimens. The present-day helium in the rock represents from 3 to $27 \%$ of the helium formed in $2.9 \times 10^{8} \mathrm{yr}$, the potassium-argon age of the rock. The variation in three clay samples is somewhat greater. Assuming $0.2 \%$ rock porosity, the amount of helium in water is $20.34 \mathrm{nl} / \mathrm{g}$ rock at DRB 6 , which represents about $7-1 / 2 \%$ of the helium in the rock and water. Thus, considering the helium in the water $(0.34 \mathrm{nl} / \mathrm{g}$ rock), and the helium retained by the rock $(4.2 \mathrm{n} 1 / \mathrm{g}$ rock), the total accumulation is $4.54 \mathrm{nl} / \mathrm{g}$ rock. Dividing this accumulation by the helium generating rate of $4 ! \times 10^{-8} \mathrm{n} 1 \mathrm{He} / \mathrm{g}$ rock per year, 11 million years is required to generate the helium. 
- No significant changes have occurred in the rate of transfer of helium from rock to water during this 11nillion year period. Helium is assumed not to have accumulated in the rock and then been released recently to the water either because the presence of water is recent or because of some change in the transfer mechanics or coefficients.

- The top of the crystalline rock is now about 650 feet below sea level and the geologic-hydrologic history (Table 14) indicates it has probably been below sea level at least since Eocene time ( 250 million years ago). The crystalline rock has probably always been saturated with water since the beginning of the Tuscaloosa deposition even before it sank below sea level. However, the extent to which changes in the dissolved solids concentration in the water may alter the mechanics of helium release from the rock are not known.

- These computations assume that the helium was generated by the same type of rock as that in the area in which it is found. This is a very reasonable assumption. However, it is possible that a granite intrusion with a higher content of uranium and thorium may have contributed some of the helium. For example, assume the helium-generating rock contains $20 \mathrm{ppm}$ uranium, a very unlikely value as this is the maximum value reported ${ }^{10}$ for 242 analyses of silicic igneous rock from all over the world. There is on the average four times more thorium than uranium in granite rocks. ${ }^{10}$ So in the assumed helium-generating rock there would be $80 \mathrm{ppm}$ of thorium. These concentrations would give this rock a helium-generating rate of $370 \times 10^{-14} \mathrm{cc}$ He per $\mathrm{g}$ rock per year and would still require 90,000 years to generate the observed accumulation of helium in the water.

- The calculation also assumes that the volume and density of the rock in which the helium was generated are equal to the volume and density of the rock in which it has accumulated, although these two volumes need not consist of the same kind of rock. If the volume of rock in which the helium was generated were smaller than the volume of accumulation (the volume of rock explored), a longer period of accumulation would be required. If the helium were generated in a large volume of rock and concentrated in the explored volume of rock, then a shorter time of accumulation would be indicated. However, the helium occurs in solution with water and not as a free gas. Laboratory and field studies ${ }^{11}$ showed that helium is a 
highly satisfactory tracer of water if there is little opportunity for loss to the atmosphere. This finding would indicate that helium in solution moves with the water and could not concentrate independently of the water.

- The previous calculations presuppose that no helium has been lost from the rock during the past 11 million years. If helium has been lost, then the length of time to accumulate the observed quantity of helium must be correspondingly greater. It would be nearly impossible to observe leakage directly because the high porosity, permeability, and the quantity of water naturally flowing in the Tuscaloosa formation would make the slight amount of helium leaking from the crystalline rock into that formation undetectable. However, if any significant quantity of helium were leaking out of the rock, the observed quantity of helium could not accumulate.

The measurements of nitrogen and argon in DRB 6 water (Table 17) are about 10 to $50 \%$ higher than the calculated amounts of these gases dissolved in water in equilibrium with a "mean" atmosphere at $20^{\circ} \mathrm{C}$. These results and the previously observed effervescence of these gases from surfacing rock water are mutually confirmatory. The fact that the water is supersaturated with both nitrogen and argon could suggest one or more of the following:

- The average atmospheric temperature was near $0^{\circ} \mathrm{C}$ when this water entered the rock system from the surface.

- The addition of salts to the water has subsequently reduced the solubilities of the gascs in the water.

- Some of the water that entered the rock from the surface has been assimilated as pure water into the rock minerals.

- Subsurface processes are producing both nitrogen and argon.

The measured hydrogen content of DRB 6 water is up to 35 times the calculated hydrogen content of water in equilibrium with atmospheric air. Henry's Law calculations for previous analyses of effervesced gas indicate that the hydrogen content is perhaps even higher in water from certain other wells. No mechanism for hydrogen generation is postulated at this time.

A low oxygen content of the rock water relative to surface water in equilibrium with air is expected because of oxygen scavenging by the rock minerals. In fact, the dissolved oxygen would be expected to be immeasurably low if the water were 
in the rock long enough to approach thermodynamic equilibrium. As in the case of hydrogen, the measured value of oxygen content (Table 17) and that obtained by application of Henry's Law to measurements of oxygen in effervesced gas are in substantial agreement. The oxygen consumption reactions may be rate-limited.

\section{SAPROLITE}

In the Piedmont province of the Southeastern states much of the crystalline rock at the surface is not hard or consolidated, but weathered to soft clayey or sandy material. Relic structure of the rock is commonly visible in outcrop, but the material is soft and may be easily crumbled by hand. This weathered clayey material derived from in situ chemical breakdown of crystalline rock is called saprolite. Saprolitic material not only occurs in the Piedmont province where the crystalline rocks are at the surface, but also in the Atlantic Coastal Plain province at the upper boundary of the crystalline rock. The position of buried saprolite indicates that, if the weathering process were exclusively a subaerial process, it developed before Late Cretaceous time, but after the period of erosion that reduced the crystalline rock mountains that supplied the Triassic sediments. At that time, erosion removed 6000 to 8000 feet of Triassic sediment, and left a plain with only 30 to 40 feet of local relief.

A geologic section of the saprolite is given in Table 10, and its chemistry is given in Table 5 . The sequence of samples from Wells P6R, DRB 8, and P8R shows a fairly constant silica and alumina content and an irregular ferric oxide content, but a progressive upward leaching of ferrous iron, magnesium, calcium, and sodium. Potassium appears to be uniform in the saprolite and crystalline rock. Hydration increases upward. AlI of the trends are to be expected as soluble cation salts are removed during the weathering of metamorphic rocks.

The water quality changes abruptly in crossing the saprolite; yet because of the low permeability, it is extremely difficult to obtain water samples from saprolitic material. The quality of water in the saprolite was determined by pressure extraction of water from rock cores 3 to 4 feet in length. The extracted water was analyzed by techniques that can be used for only a few milliliters of sample (Table 11). In a very general way, sulfate, chloride, potassium, and calcium appear to increase with increasing depth in the saprolite. The high phosphate content of the samples from Wells P6R, P7R, and P8R may indicate some inadvertent contamination with drilling mud. 


\section{TRIASSIC ROCK}

Whereas the ground water circulation systems in the Coastal Plain sediments and in the crystalline metamorphic rock are grossly determinable from measurements of the hydraulic heads in observation wells, the ground water system of the Triassic formation is not. Wells that penetrate the interior of the Triassic basin have a hydraulic head between 100 and 170 psi higher than that of surrounding rock bodies. This head is not from a lithostatic load nor is it a relic head preserved from some previous time. ${ }^{12}$ The most probable explanation is that osmotic phenomena cause an inward fluid driving force that can only be balanced by an increase in hydraulic head. The membrane characteristics of the Triassic mudstone, the chemical differences between Triassic water and the surrounding water, and the extremely low permeability of the Triassic rock contribute to the preservation of this head. Until the first well was drilled into the Triassic basin, the hydraulic forces were balanced by the electrochemical forces, and there was no flow into, out of, or within the Triassic rocks.

The concentration of dissolved constituents is greater in the water from Triassic rock $(12,000$ to $18,000 \mathrm{mg} / 1$, Table 4) than in the water from the crystalline rock $(6000 \mathrm{mg} / 1)$. Like the crystalline rock, the dominant cations are calcium (2200 to $4600 \mathrm{mg} / \mathrm{l}$ ) and sodium (2100 to $2900 \mathrm{mg} / \mathrm{l})$, but the dominant anion is exclusively chloride $(7500$ to $10,000 \mathrm{mg} / 1)$. Sulfate ion concentration is very low ( $\sim 0$ to $80 \mathrm{mg} / 1$ ), as are the concentrations of most of the other cations and anions.

The dissolved solids content of waters collected from the Triassic basin has led to conjecture that these waters may in part have a marine origin. As a partial test of this hypothesis, an iodine analysis was performed on a sample collected from DRB 10 at a depth of 4212 feet. The average result from five determinations was $0.59 \pm 0.06 \mathrm{ppm}$ iodine by weight, corresponding to an iodine/chlorine ratio of $8.8 \times 10^{-5}$. The corresponding value ${ }^{10}$ for ocean water is $2.6 \times 10^{-6}$, or a factor of about 30 less than in the DRB 10 sample. Thus, a sea water origin is not corroborated by this test.

Water from Triassic rock has a nearly zero sulfate content, and between 50 and 70 percent of the total cation content is calcium (Figure 10); thus, although sodium chloride may occur, the dominant ions are calcium and chloride. The water appears to be unique as it is depleted in sulfate compared to the leach solution from Triassic mudstone (Figure 10 and Table 15). Water from Triassic rock is deficient in sodium ion when compared to sea water. No evidence of evaporite deposits were found in the Triassic rock in the drilling program at SRP, but some has been discovered in other Triassic basins [Glauberite $\left(\mathrm{Na}_{2} \mathrm{SO}_{4} \cdot \mathrm{CaSO}_{4}\right)$ and salt (NaC1) casts]. 
The sample labeled "DRB 9 Triassic" in Figure 10 was collected while the well was being drilled in Triassic rock and 570 feet before the well penetrated crystalline rock. This we 11 is near the very edge of the Triassic basin (Figure 2), and if the osmotic hypothesis is correct, the water should be fresher, which it is. Also, due to its edge position in the Triassic basin, some diffusional mixing with water from crystalline rock should have taken place, which may be indicated by analytical values between typical Triassic water and typical crystalline rock water (Figure 10).

We11 PI2R is within the borders of the Triassic basin (Figure 2), but penetrates the Triassic by only 184 feet. Thus, it also, if the osmotic explanation of the high Triassic head is correct, should be fresher than typical Triassic basin water, which it is (Table 4). This water is much higher in its proportion of sodium than typical water from the Triassic basin (Figure 10), perhaps from a local concentration of sodium salts.

Water was squeezed from core samples of the basal Tuscaloosa formation and from the weathered upper part of the Triassic rock from We11s DRB 10 and P9R. These water samples were analyzed by neutron activation, $x$-ray fluorescence, and atomic absorption techniques (Table 18).

All the isotopic ratios shown on Figure 11 for Triassic waters are from the same we11, DRB 10, but taken at different depths. Hydraulic tests made while this well was being drilled indicated that, even though these water samples were collected when the well was at different depths, all of the water was coming from the same zone, between 1250 and 1493 feet. Comparison of the chemical analyses generally support the same conclusion, even though the deepest sample contains less dissolved material. However, the isotopic data show that there must be more than one source of water in this we11. The isotopic analyses also indicate that the Triassic water is not a simple mixture of sea water and precipitation.

Gas effervesced from Triassic We11s DRB 10 and DRB 11. Gas samples were collected by permitting the water from these wells to flow through an inverted water-filled bottle. The wells are free-flowing, and the total water flow-through during the sample collection was not determined. The analyses of these samples are given in Table 19. This table also shows for comparison the effervesced gas and total gas from water from DRB 6. 
The dissolved gas from the Triassic Well DRB 10 is principally two-thirds hydrogen and one-third nitrogen by volume with other minor constituents present including helium. Helium is believed to have significance in the Triassic similar to its significance in the crystalline rock.

The origin of hydrogen and nitrogen is not definitely known, but an igneous intrusion into a coal bed or simply compaction of the coal might release volatiles. Analyses of Triassic coal in the Deep River Basin, ${ }^{13} 170$ miles north of SRP, show a hydrogento-nitrogen ratio of 2.5 to 1 , about the same ratio as the gas from water from DRB 10. However, drilling in the Triassic basin at SRP has thus far not encountered any igneous rock nor has it encountered any coal or even black shale.

The analysis of gas from the water from DRB 11 is surprising in that it does not show a similarity to the gas from DRB 10. Another sample from DRB 11 should be collected and analyzed before these results can be interpreted. 


\section{CONCLUSIONS}

The foregoing analyses indicate that the origin of neither the water found in the crystalline rock nor that found in the Triassic rock can be determined using simple closed system models. Contradictions appear if a simple origin, such as sea water, rain water, or water from the Coastal Plains sediments, is hypothesized. The complexity of these two waters is an indication that their rates of movement are slow because more rapidly moving water would provide more definitive clues for determining their origins. The origins of these two waters are lost in antiquity.

Although the origins of these two waters are still in doubt, the age of the water from the crystalline metamorphic rock is fairly reliably estimated to be at least 840,000 years. Sampling of the Triassic water does not permit as reliable an estimate for its age, but very likely it is older than the water in the crystalline rock. 


\section{LIST OF TABLES}

Table

$1 \quad$ Analyses of Water from Surface Sources 52

2 Analyses of Water from Coastal Plain Formations 56

3 Analyses of Water from Crystalline Metamorphic Rock 63

$4 \quad$ Analyses of Water from Triassic Rock 75

5 Analyses of Saprolite and Crystalline Metamorphic Rock 80

6 Isotopic Composition of Argon Dissolved in Water from the Crystalline Metamorphic Rock Compared with the Isotopic Composition of Argon in Air 83

7 Thorium, Uranium, and Helium Contents of Selected Core Samples of Crystalline Metamorphic Rock 83

8 Ratio of ${ }^{34} \mathrm{~S} /{ }^{32} \mathrm{~S}$ in Sulfide Minerals in Crystaliine Metamorphic Rock Compared to that of Sulfate in Water 84

$9 \quad$ Range and Median Values for Chemical Constituents and Properties of Water from Coastal Plain Sediments 85

10 Generalized Log of Saprolite Cores 86

11 Analyses of Pore Water from Saprolite 87

12 Electrical Conductivity of Water from We11 DRB 1188

13 Geologic Formations Underlying SRP 89

14 Geologic-Hydrologic History of the SRP Region 90

15 Analyses of Leach Solutions from Ground Rock 92

16 Selected Analyses of Effervesced Gas from Wells in Crystalline Metamorphic Rock 93

17 Gases Dissolved in Water Samples from Wells DRB 6 and DRB 794

18 Analyses of Pore Water from Tuscaloosa and Triassic Rock Samples 95

19 Analyses of Dissolved Gas in Water from Triassic Rock 96 
TABLE 1

Analyses of Water from Surface Sources

Source: Hollow (Holley) Creek at S. C. Highway 125 Bridge.

\begin{tabular}{|c|c|c|c|c|c|c|}
\hline Date Scmpled: & $\begin{array}{l}\text { Spring } 71 \\
5-11-71\end{array}$ & $\begin{array}{l}\text { Summer } 71 \\
8-24-71\end{array}$ & $\begin{array}{l}\text { Fal2 } 71 \\
11-30-71\end{array}$ & $\frac{\text { Winter } 71}{2-14-72}$ & $\frac{1-72}{2-14-72}$ & $\begin{array}{l}\text { Swomer } 72 \\
9-18-72\end{array}$ \\
\hline \multicolumn{7}{|c|}{ Isotopic Ratios: } \\
\hline${ }^{18} \mathrm{O} /{ }^{16} \mathrm{O}^{\alpha}$ & -4.50 & -4.54 & -4.78 & -4.87 & - & \\
\hline${ }^{2} \mathrm{H} /{ }^{1} \mathrm{H}^{\alpha}$ & -24.5 & -24.4 & -25.6 & -26.7 & & \\
\hline${ }^{34} \mathrm{~S} /{ }^{32} \mathrm{~s} d$ & & & $6 \pm 2$ & & & \\
\hline \multicolumn{7}{|c|}{ Dissolved Gases, mol $: b$} \\
\hline $\mathrm{O}_{2}, \mathrm{ppm}$ & 9.4 & 7.0 & 8.8 & 10.1 & & \\
\hline $\mathrm{CO}_{2}, \mathrm{ppm}$ & 2.55 & 29.1 & & & & \\
\hline \multicolumn{7}{|l|}{$\mathrm{N}_{2}$} \\
\hline A & & & & & : & \\
\hline \multicolumn{7}{|l|}{$\mathrm{CH}_{4}$} \\
\hline \multicolumn{7}{|l|}{$\mathrm{H}_{2}$} \\
\hline $\mathrm{He}$ & & & & & $\therefore$ & \\
\hline
\end{tabular}

\begin{tabular}{|c|c|c|c|c|c|c|}
\hline & $b$ & $b$ & $b$ & $b$ & $c$ & c \\
\hline $\mathrm{SiO}_{2}$ & 2.5 & 0.43 & 1.3 & 0.97 & 1.15 & \\
\hline $\mathrm{Fe}$ & 0.7 & 0.82 & 0.31 & 0.32 & 0.48 & 0.90 \\
\hline$M n$ & $<0.05$ & $<0.05$ & 0.05 & $<0.05$ & & \\
\hline $\mathrm{Cu}$ & 0.10 & 0.04 & 0.07 & 0.14 & & \\
\hline $\mathrm{Mg}$ & 6.4 & 3.2 & 17.6 & 1.8 & 0.30 & 0.28 \\
\hline $\mathrm{Ca}$ & 2.5 & 1.1 & 0.52 & 0.22 & 0.39 & $<0,11$ \\
\hline $\mathrm{Na}$ & 1.0 & 1.4 & 0.9 & 1.6 & 1.86 & 1.35 \\
\hline K & 0.50 & 0.50 & 0.4 & 0.55 & 0.32 & 0.50 \\
\hline $\mathrm{HCO}_{3}$ & 24.4 & 28.3 & 2.5 & 4.6 & 3.7 & 1.5 \\
\hline $\mathrm{SO}_{4}$ & $<2$ & 0.35 & $<2$ & 5.1 & 0.27 & 1.1 \\
\hline $\mathrm{Cl}$ & 1.6 & 0.70 & 1.8 & 1.5 & $<1$ & 1.8 \\
\hline $\mathrm{NO}_{3}$ & 0.54 & 0.09 & 0.09 & 0.27 & 1.6 & 0.003 \\
\hline $\mathrm{PO}_{4}$ & 0.43 & I. 30 & $<0.3$ & $<0.3$ & & \\
\hline Total (Residue): & 7.9 & 17.3 & 17.0 & 20.6 & & \\
\hline $\begin{array}{l}\text { Hardness as } \\
\qquad \mathrm{CaCO}_{3}(\mathrm{mg} / \ell):\end{array}$ & 13.1 & 16.0 & 12.9 & 7.9 & & \\
\hline $\mathrm{pH}$ & 6.7 & 5.2 & 7.0 & 6.02 & 6.7 & \\
\hline
\end{tabular}

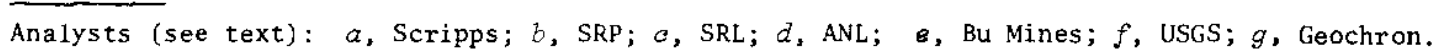


TABLE 1 (Continued)

Source: Upper Three Runs Creek at S. C. Highway 125 Bridge

\begin{tabular}{|c|c|c|c|c|c|}
\hline Date Scompled & $\begin{array}{l}\text { Spxing } 71 \\
5-11-71\end{array}$ & $\begin{array}{l}\text { Stumer } 71 \\
8-24-71\end{array}$ & $\begin{array}{l}\text { Fal2 } 71 \\
11-30-71\end{array}$ & $\frac{\text { Winter } 71-72}{2-14-72} \frac{-14-72}{2-14}$ & $\begin{array}{l}\text { Summer } 72 \\
9-18-72\end{array}$ \\
\hline \multicolumn{6}{|c|}{ Isotopic Ratios: } \\
\hline${ }^{18} \mathrm{O} /{ }^{16} \mathrm{O}^{a}$ & -4.59 & -4.73 & -5.05 & -5.09 & \\
\hline${ }^{2} \mathrm{H} /{ }^{1} \mathrm{H}^{a}$ & -24.3 & -25.2 & -27.7 & -27.8 & \\
\hline${ }^{34} \mathrm{~S} /{ }^{32} \mathrm{~S}^{d}$ & & & $0.4 \pm 0.3$ & & \\
\hline \multicolumn{6}{|c|}{ Dissolved Gases, mol $\%: b$} \\
\hline $\mathrm{O}_{2}, \mathrm{ppm}$ & 8.3 & 7.3 & 8.6 & 10.1 & \\
\hline $\mathrm{CO}_{2}, \mathrm{ppm}$ & & 4.1 & & & . \\
\hline \multicolumn{6}{|l|}{$\mathrm{N}_{2}$} \\
\hline \multicolumn{6}{|l|}{ A } \\
\hline \multicolumn{6}{|l|}{$\mathrm{CH}_{4}$} \\
\hline \multicolumn{6}{|l|}{$\mathrm{H}_{2}$} \\
\hline $\mathrm{He}$ & & & & & \\
\hline
\end{tabular}

Dissolved Solids, mg/ $\mathrm{l}$ :

\begin{tabular}{|c|c|c|c|c|c|c|}
\hline & $b$ & $b$ & $b$ & $b$ & $c$ & $c$ \\
\hline $\mathrm{SiO}_{2}$ & 4.34 & 0.83 & $<0.08$ & 1.7 & 2.31 & \\
\hline $\mathrm{Fe}$ & 0.4 & 0.35 & 0.26 & 0.23 & $<0.02$ & $<0.02$ \\
\hline $\mathrm{Mn}$ & $<0.05$ & $<0.05$ & $<0.05$ & $<0.05$ & & \\
\hline $\mathrm{Cu}$ & $<0.02$ & 0.01 & 0.11 & 0.14 & & \\
\hline $\mathrm{Mg}$ & 4.6 & 3.1 & & 2.4 & 0.33 & 0.80 \\
\hline $\mathrm{Ca}$ & 5.3 & 1.3 & 0.52 & 0.52 & 0.89 & 5.9 \\
\hline $\mathrm{Na}$ & 0.70 & 1.75 & 1.4 & 1.7 & 1.56 & 2.8 \\
\hline K & 0.55 & 0.45 & 0.6 & 0.65 & 0.38 & 9.3 \\
\hline $\mathrm{HCO}_{3}$ & 3.2 & 4.0 & 2.2 & 5.0 & 2.3 & 6.0 \\
\hline $\mathrm{SO}_{4}$ & 0.35 & 1.91 & 0.84 & 0.70 & 2.6 & 1.7 \\
\hline $\mathrm{Cl}$ & 1.5 & 0.65 & 2.5 & 0.78 & $<1$ & 4.6 \\
\hline $\mathrm{NO}_{3}$ & 0.54 & 0.18 & 0.90 & 0.53 & 2.9 & 0.005 \\
\hline $\mathrm{PO}_{4}$ & 0.47 & 1.53 & $<0.3$ & $<0.3$ & & \\
\hline tal (Residue): & 27.8 & 12.8 & 11.0 & 32.0 & & \\
\hline rdness as $\mathrm{CaCO}_{3}$ : & 12.8 & 15.8 & 56.8 & 11.2 & & \\
\hline & 6.3 & 5.9 & 6.9 & 6.0 & 6.1 & \\
\hline
\end{tabular}




\begin{tabular}{|c|c|c|c|c|c|c|}
\hline \multicolumn{7}{|c|}{ ower Three Runs at S. C. F } \\
\hline Date Sampled & $\begin{array}{l}\text { Spring } 71 \\
5-11-71\end{array}$ & $\begin{array}{l}\text { Summer } 71 \\
8-24-71\end{array}$ & $\begin{array}{l}\text { Fal2 } 71 \\
11-30-71\end{array}$ & $\frac{\text { Winter }}{2-14-72}$ & $\frac{1-72}{2-14-72}$ & $\begin{array}{l}\text { Summer } 72 \\
9-18-72\end{array}$ \\
\hline \multicolumn{7}{|l|}{ Isotopic Ratios: } \\
\hline${ }^{18} 0 /{ }^{16} 0^{a}$ & -3.56 & -2.64 & -4.49 & -3.74 & & \\
\hline${ }^{2} \mathrm{H} /{ }^{1} \mathrm{H}^{a}$ & 19.9 & -14.8 & -22.7 & -21.6 & & \\
\hline${ }^{32} \mathrm{~S} /{ }^{34} \mathrm{~S}^{d}$ & & & 6.7 & & & \\
\hline \multicolumn{7}{|c|}{ Dissolved Gases, mol $\frac{0}{b} b$} \\
\hline $\mathrm{O}_{2}, \mathrm{ppm}$ & 5.2 & 5.9 & 5.1 & 10.1 & & \\
\hline $\mathrm{CO}_{2}, \mathrm{ppm}$ & 35.7 & 20.9 & & & & \\
\hline \multicolumn{7}{|l|}{$\mathrm{N}_{2}$} \\
\hline \multicolumn{7}{|l|}{ A } \\
\hline \multicolumn{7}{|l|}{$\mathrm{CH}_{4}$} \\
\hline \multicolumn{7}{|l|}{$\mathrm{H}_{2}$} \\
\hline \multicolumn{7}{|l|}{$\mathrm{He}$} \\
\hline \multicolumn{7}{|c|}{ Dissolved Solids, mg/l: } \\
\hline & $b$ & $b$ & $b$ & $b$ & $c$ & $c$ \\
\hline $\mathrm{SiO}_{2}$ & 5.31 & 1.0 & 2.95 & 1.4 & 2.31 & \\
\hline $\mathrm{Fe}$ & 0.4 & 0.33 & 0.25 & 0.30 & 0.35 & $<0.2$ \\
\hline Mn & $<0.05$ & $<0.05$ & $<0.05$ & $<0.05$ & & \\
\hline $\mathrm{Cu}$ & 0.15 & 0.01 & 0.11 & 0.16 & & \\
\hline $\mathrm{Mg}$ & 1.1 & 6.7 & 19.0 & 7.2 & 0.65 & 0.80 \\
\hline $\mathrm{Ca}$ & 19.3 & 5.4 & 2.4 & 2.9 & 4.65 & 5.9 \\
\hline $\mathrm{Na}$ & 2.5 & 6.4 & 1.6 & 17.5 & 3.0 & 2.8 \\
\hline K & 3.3 & 1.1 & 2.0 & 1.8 & 1.64 & 9.2 \\
\hline $\mathrm{HCO}_{3}$ & 34.4 & 20.4 & 16.1 & 17.4 & 27.5 & 74 \\
\hline $\mathrm{SO}_{4}$ & 0.49 & 0.70 & 3.2 & 4.9 & 2.4 & 1.5 \\
\hline $\mathrm{Cl}$ & 1.3 & 1.2 & 2.5 & 1.3 & $<1$ & 3.7 \\
\hline $\mathrm{NO}_{3}$ & 0.52 & 0.08 & 0.53 & 0.53 & 3.0 & 0.003 \\
\hline $\mathrm{PO}_{4}$ & 0.38 & 0.61 & 0.32 & 6.1 & & \\
\hline Total (Residue): & 71.6 & 55.8 & 36.4 & 49.9 & & \\
\hline Hardness as $\mathrm{CaCO}_{3}$ : & 21.1 & 41.0 & 20.5 & 37.0 & & \\
\hline $\mathrm{pH}:$ & 6.8 & 6.5 & 7.48 & 6.88 & 6.8 & \\
\hline
\end{tabular}


TABLE 1 (Continued)

Source: Savannah River at U. S. 301 Bridge

\begin{tabular}{|c|c|c|c|c|c|c|}
\hline Date Sampled & $\begin{array}{l}\text { Spring } 71 \\
5-11-71\end{array}$ & $\begin{array}{l}\text { Summer } 72 \\
8-24-71\end{array}$ & $\begin{array}{l}\text { Fal2 } 71 \\
11-30-71\end{array}$ & \multicolumn{2}{|c|}{ Winter 71-72 } & $\begin{array}{l}\text { Summer } 72 \\
9-18-71\end{array}$ \\
\hline \multicolumn{7}{|l|}{ Isotopic Ratios: } \\
\hline${ }^{18} 0 /{ }^{16} 0^{\alpha}$ & -4.2 & -4.42 & -3.88 & -4.56 & . & \\
\hline${ }^{2} \mathrm{H} /{ }^{1} \mathrm{H}^{a}$ & -23.3 & -24.9 & -22.5 & -26.8 & & \\
\hline${ }^{34} \mathrm{~S} /{ }^{32} \mathrm{~S}^{d}$ & & & 8.4 & & & \\
\hline \multicolumn{7}{|c|}{ Dissolved Gases, mol $::^{b}$} \\
\hline $\mathrm{O}_{2}, \mathrm{ppm}$ & 4.0 & 4.6 & 7.52 & 10.0 & & \\
\hline $\mathrm{CO}_{2}, \mathrm{Ppm}$ & 14.5 & 4.9 & & & & \\
\hline \multicolumn{7}{|l|}{$\mathrm{N}_{2}$} \\
\hline \multicolumn{7}{|l|}{ A } \\
\hline \multicolumn{7}{|l|}{$\mathrm{CH}_{4}$} \\
\hline \multicolumn{7}{|l|}{$\mathrm{H}_{2}$} \\
\hline \multicolumn{7}{|l|}{$\mathrm{He}$} \\
\hline \multicolumn{7}{|c|}{ Dissolved Solids, mg/l: } \\
\hline & $b$ & $b$ & $b$ & $b$ & $c$ & $c$ \\
\hline $\mathrm{SiO}_{2}$ & 5.56 & 1.1 & 1.2 & 1.7 & 2.31 & \\
\hline $\mathrm{Fe}$ & 0.7 & 0.44 & 0.08 & 0.17 & 0.48 & $<0.2$ \\
\hline Mn & $<0.05$ & $<0.05$ & $<0.05$ & $<0.05$ & & \\
\hline $\mathrm{Cu}$ & 0.08 & 0.13 & 0.03 & 0.20 & & \\
\hline $\mathrm{Mg}$ & 3.7 & 5.7 & 18.2 & 3.9 & 1.27 & 1.2 \\
\hline $\mathrm{Ca}$ & 2.4 & 2.2 & 1.5 & 1.35 & 1.88 & 0.76 \\
\hline $\mathrm{Na}$ & 3.5 & 7.8 & 7.0 & 27.0 & 4.96 & 7.4 \\
\hline $\mathrm{K}$ & 0.80 & 1.65 & 1.5 & 1.57 & 1.57 & 1.5 \\
\hline $\mathrm{HCO}_{3}$ & 14.0 & 4.77 & 14.4 & 12.1 & 18.6 & 24 \\
\hline $\mathrm{SO}_{4}$ & 4.80 & 3.2 & 0.7 & 6.0 & 5.0 & 6.0 \\
\hline $\mathrm{C} 1$ & 3.3 & 2.6 & 4.0 & 1.6 & 3.2 & 5.3 \\
\hline $\mathrm{NO}_{3}$ & 0.52 & 0.26 & 0.53 & 4.43 & 2.8 & 1.05 \\
\hline $\mathrm{PO}_{4}$ & 0.19 & 1.35 & 0.47 & & & \\
\hline Total (Residue): & 42.3 & 25.0 & 39.3 & 45.7 & & \\
\hline Hardness as $\mathrm{CaCO}_{3}$ : & 8.4 & 28.9 & 19.1 & 19.6 & & \\
\hline pH: & 7.1 & 7.9 & 6.9 & 6.58 & 6.8 & \\
\hline
\end{tabular}


TABLE 2

Analyses of water from Coastal Plain Fomations

Part A. Continuously Pumped Wel1s, Periodic Analyses

Source: Well 905-31A, Tuscaloosa Formation

\begin{tabular}{|c|c|c|c|c|c|c|}
\hline bate Sampled: & $\begin{array}{l}\text { Spring } 77 \\
2-i 1-71\end{array}$ & $\begin{array}{l}\text { Surmer ?7 } \\
y-3:-7 ?\end{array}$ & $\begin{array}{l}H a l l 11 \\
11-18-7 !\end{array}$ & 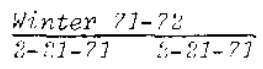 & $\begin{array}{l}\text { ipring } \% \\
\therefore-i 9-73\end{array}$ & $\begin{array}{l}\text { Summer } 7: \\
\hat{y}-1 \mathrm{i}-7:\end{array}$ \\
\hline \multicolumn{7}{|c|}{ Isotopie Ratios: } \\
\hline${ }^{16} 0 /^{16} 0^{a}$ & -5.04 & -5.08 & -4.96 & -4.94 & & \\
\hline${ }^{2} \mathrm{H} /{ }^{3} \mathrm{H} / \mathrm{I}$ & -27.7 & -27.7 & -27.6 & -27.4 & & \\
\hline${ }^{34} \mathrm{~S} /{ }^{32} \mathrm{Sil}$ & & & 6.0 & & & \\
\hline
\end{tabular}

bissolved Gases, mol: ${ }^{b}$

$$
\begin{array}{ll}
\mathrm{O}_{2}, \text { ppm } & 9.9 \\
\mathrm{CO}_{2}, \text { ppm } & 9.8 \\
\mathrm{~N}_{2} & \\
\mathrm{~A} & \\
\mathrm{CH}_{4} & \\
\mathrm{H}_{2} & \\
\mathrm{He} &
\end{array}
$$$$
\mathrm{CO}_{2}, \text { ppm } 9.8
$$

Lissolved Solids, mg/e:

$\begin{array}{lcccccc} & i & i & 2 & 0 & 0 & \\ \mathrm{SiO}_{2} & 7.0 & 0.70 & 0.64 & 0.56 & 0.6 & 0.2 \\ \mathrm{Fe} & <0.05 & <0.05 & <0.05 & 0.012 & 0.18 & <0.2 \\ \mathrm{Mn} & <0.05 & <0.05 & <0.05 & <0.05 & & \\ \mathrm{Cu} & 0.10 & <0.02 & 0.25 & 0.30 & & \end{array}$

$\mathrm{Mg} \quad 3.0$

Ca 8.7

$\mathrm{Na} \quad 6.0$

K

$\mathrm{HCO}_{3} \quad 9.5$

$\mathrm{SO}_{4} \quad 0.0$

Cl 2.1

$\mathrm{NO}_{3}$

$\mathrm{PO}_{4}$

$<0.02$

4.2

0.68

1.8

1.3

1.7

$0.18 \quad 0.14$

0.68

0.11

0.30

$<0.11$

1.4

1.75

1.15

1. 25

$\begin{array}{lllll}2.1 & 3.8 & 5.4 & & 0.0\end{array}$

$<2$

1.6

Total (Residue): 33.6

$<0.03$

1.1

2.3

0.5

0.8

$<1<1$

$0.03<0.02$

$1.5<2$

5.2

$<0.03$

$<0.03$

Hardness as $\mathrm{CaCO}_{3}: 13.7$

19.1

6.920 .8

$\mathrm{pH}$ :

Analysts (see text): $a$, Scripps; $b$, SRP; $c$, SRL; $d$, ANL; $e$, Bu Mines, $f$, IISGS; g, Ceochron. 
TABLE 2, Part A, Continued

\begin{tabular}{|c|c|c|c|c|c|}
\hline \multirow{2}{*}{ iate sompled: } & \multirow{2}{*}{$\begin{array}{l}\text { Spring } 71 \\
5-21-71\end{array}$} & \multirow{2}{*}{$\begin{array}{l}\text { Summer } 71 \\
8-31-71\end{array}$} & \multirow{2}{*}{$\begin{array}{l}\text { Fal2 } 71 \\
12-13-71\end{array}$} & \multicolumn{2}{|c|}{ Winter $71-72$} \\
\hline & & & & $2-29-72$ & $2-29-72$ \\
\hline \multicolumn{6}{|l|}{ Isotopic Ratios: } \\
\hline${ }^{18} \mathrm{O} /{ }^{16} \mathrm{O}^{a}$ & -4.38 & -4.42 & -4.40 & -4.34 & \\
\hline${ }^{2} \mathrm{H} /{ }^{1} \mathrm{H}^{a}$ & -23.8 & -22.9 & -21.7 & -22.3 & \\
\hline${ }^{34} \mathrm{~S} / /^{32} \mathrm{~S}^{d}$ & & & -13.4 & & \\
\hline \multicolumn{6}{|c|}{ Dissolved Gases, mo1 $\%:^{b}$} \\
\hline $\mathrm{O}_{2}, \mathrm{ppm}$ & 0.0 & & & & \\
\hline $\mathrm{CO}_{2}, \mathrm{ppm}$ & 16.8 & 12.9 & & 38 & \\
\hline \multicolumn{6}{|l|}{$\mathrm{N}_{2}$} \\
\hline \multicolumn{6}{|l|}{ A } \\
\hline \multicolumn{6}{|l|}{$\mathrm{CH}_{4}$} \\
\hline \multicolumn{6}{|l|}{$\mathrm{H}_{2}$} \\
\hline \multicolumn{6}{|l|}{$\mathrm{He}$} \\
\hline \multicolumn{6}{|c|}{ Dissolved Solids, mg/l: } \\
\hline & $b$ & $b$ & $b$ & $b$ & $c$ \\
\hline $\mathrm{SiO}_{2}$ & 10.6 & 0.85 & 3.3 & 0.70 & 0.6 \\
\hline $\mathrm{Fe}$ & 0.3 & 1.0 & 0.18 & 0.05 & $<0.05$ \\
\hline $\mathrm{Mn}$ & $<0.05$ & $<0.05$ & $<0.05$ & $<0.05$ & $<0.05$ \\
\hline $\mathrm{Cu}$ & 0.21 & 0.11 & 0.05 & 0.19 & 0.23 \\
\hline $\mathrm{Mg}$ & & 3.2 & & 3.2 & 3.5 \\
\hline $\mathrm{Ca}$ & 6.0 & 2.1 & 1.65 & 1.72 & 1.4 \\
\hline $\mathrm{Na}$ & 4.4 & 5.6 & 23.5 & 11.8 & 11.0 \\
\hline k & 4.6 & 4.3 & 4.3 & 4.3 & 4.3 \\
\hline $\mathrm{HCO}_{3}$ & 16.2 & 12.6 & 16.0 & 13.4 & 9.9 \\
\hline $\mathrm{SO}_{4}$ & 12.1 & 12.0 & 9.2 & 13.9 & 15.0 \\
\hline $\mathrm{Cl}_{1}$ & 2.1 & 1.1 & 1.2 & 0.44 & 0.59 \\
\hline $\mathrm{NO}_{3}$ & $<0.02$ & 0.09 & 0.27 & 1.32 & 0.26 \\
\hline $\mathrm{PO}_{4}$ & 0.28 & 0.48 & 1.0 & $<0.3$ & 0.3 \\
\hline Total (Residue): & 38.0 & 46.3 & 41.5 & 41.7 & 48.9 \\
\hline Hardness as $\mathrm{CaCO}_{3}$ : & 25.3 & 18.4 & 48.9 & 17.7 & 18.1 \\
\hline $\mathrm{pH}:$ & 6.6 & 5.8 & 6.6 & 6.15 & 6.6 \\
\hline
\end{tabular}


TABLE 2, Part A, Continued

Source: Well 905-43H, Tuscaloosa Formation

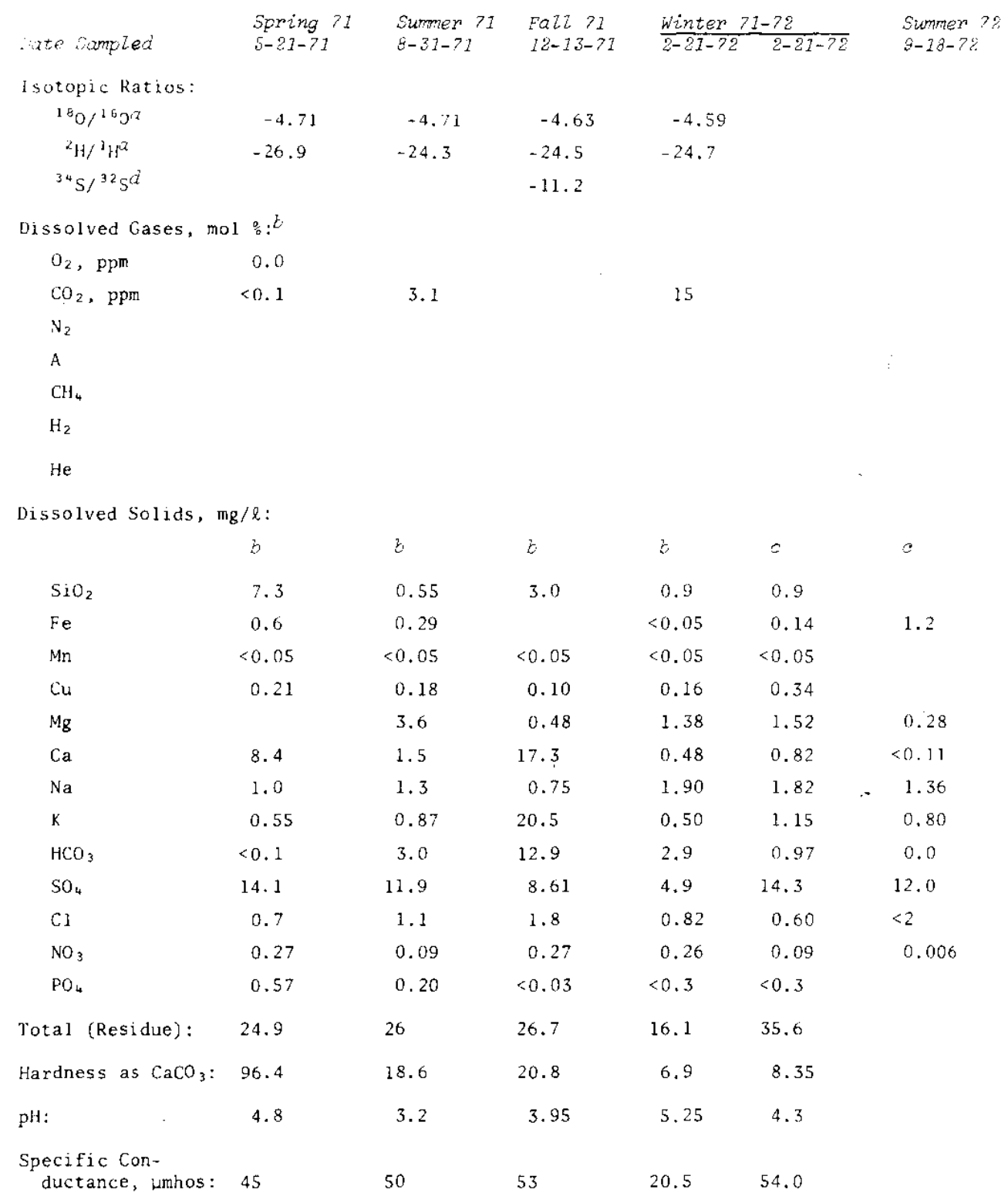


TABLE 2, Part A, Continued

Source: Well 905-67U, Tuscaloosa Formation

\begin{tabular}{|c|c|c|c|c|c|c|c|}
\hline late sampled: & $\begin{array}{l}\text { Spring } 71 \\
5-11-71\end{array}$ & $\begin{array}{l}\text { Summer } 71 \\
8-14-71\end{array}$ & $\begin{array}{l}\text { Fa22 } 71 \\
11-18-71\end{array}$ & $\frac{\text { Winter } 7}{2-21-71}$ & $\frac{1-72}{2-21-72}$ & $\begin{array}{l}\text { Spring } 72 \\
4-24-72\end{array}$ & $\begin{array}{l}\text { Summer } 72 \\
9-18-72\end{array}$ \\
\hline \multicolumn{8}{|l|}{ Isotopic Ratios: } \\
\hline${ }^{28} 0 /{ }^{16}{ }^{0}{ }^{a}$ & -4.92 & -4.86 & -4.88 & -4.83 & & & \\
\hline${ }^{2} \mathrm{H} /{ }^{1} \mathrm{H}^{a}$ & -27.2 & -26.5 & -26.5 & -26.4 & & & \\
\hline${ }^{34} \mathrm{~S} /{ }^{32} \mathrm{Sd}$ & -0.4 & & -9.5 & & & & \\
\hline \multicolumn{8}{|c|}{ Dissolved Gases, mol $\%: b$} \\
\hline $\mathrm{O}_{2}, \mathrm{ppm}$ & 8.3 & & & & & & \\
\hline $\mathrm{CO}_{2}, \mathrm{ppm}$ & 3.6 & 1.5 & & 15 & & & \\
\hline \multicolumn{8}{|l|}{$\mathrm{N}_{2}$} \\
\hline \multirow{2}{*}{\multicolumn{8}{|c|}{$\mathrm{CH}_{4}$}} \\
\hline & & & & & & & \\
\hline \multicolumn{8}{|l|}{$\mathrm{H}_{2}$} \\
\hline \multicolumn{8}{|l|}{ He } \\
\hline \multicolumn{8}{|c|}{ Dissolved Solids, $\mathrm{mg} / 1$ : } \\
\hline & $b$ & $b$ & $b$ & $b$ & $c$ & $c$ & $c$ \\
\hline $\mathrm{SiO}_{2}$ & 7.1 & 0.56 & 1.0 & 0.9 & 0.44 & 4.15 & \\
\hline $\mathrm{Fe}$ & $<0.05$ & 0.19 & $<0.05$ & $<0.05$ & 0.05 & 0.35 & $<0.2$ \\
\hline Mn & $<0.05$ & $<0.05$ & $<0.05$ & $<0.05$ & $<0.05$ & & \\
\hline $\mathrm{Cu}$ & 0.09 & 0.19 & 0.08 & 0.16 & 0.20 & & \\
\hline $\mathrm{Mg}$ & 5.2 & 1.8 & 3.5 & 1.4 & 1.5 & 0.22 & 0.2 \\
\hline $\mathrm{Ca}$ & 1.9 & 0.94 & 0.38 & 0.48 & 0.22 & 0.30 & $<0.1$ \\
\hline$N a$ & 1.3 & 1.4 & 1.3 & 1.9 & 1.6 & 1.36 & 1.4 \\
\hline K & 0.5 & 0.65 & 0.5 & 0.5 & 0.43 & 0.42 & 0.5 \\
\hline $\mathrm{HCO}_{3}$ & 3.44 & 1.5 & 0.99 & 2.9 & 0.97 & 0.0 & $<0.6$ \\
\hline $\mathrm{SO}_{4}$ & 1.27 & 0.71 & 0.42 & 4.9 & 3.5 & 1.2 & 1.5 \\
\hline $\mathrm{Cl}$ & 1.6 & 1.26 & 3.0 & 0.82 & 0.74 & $<1$ & 2.8 \\
\hline $\mathrm{NO}_{3}$ & 0.26 & 0.09 & 0.08 & 0.26 & 0.27 & 0.32 & $<0.01$ \\
\hline $\mathrm{PO}_{4}$ & 0.09 & 0.20 & 0.56 & $<0.3$ & $<0.3$ & & \\
\hline Total (Residue): & 20.6 & 9.9 & 13.4 & 16.1 & 27.3 & & \\
\hline Hardness as $\mathrm{CaCO}_{3}$ & 10.5 & 9.8 & 15.5 & 6.9 & 6.7 & & \\
\hline $\mathrm{pH}:$ & 5.0 & 4.8 & 6.0 & 5.5 & 5.15 & 5.0 & 5.6 \\
\hline $\begin{array}{l}\text { Specific Con- } \\
\text { ductance, umhos: }\end{array}$ & $: \quad 18.0$ & 23.5 & 18.0 & 20.5 & 19.0 & & \\
\hline
\end{tabular}


TABLE 2, Part A, Continued

Source: Well 905-72G, Tuscaloosa Formation, depth $580 \mathrm{ft}$, ground elevation $293 \mathrm{ft}$

\begin{tabular}{|c|c|c|c|c|c|c|c|}
\hline Late Sampled: & $\begin{array}{l}\text { Spring } 71 \\
5-1-71\end{array}$ & $\begin{array}{l}\text { Summer } 71 \\
9-31-71\end{array}$ & $\begin{array}{l}\text { Fall } 71 \\
12-31-71\end{array}$ & $\frac{\text { Winter ? }}{2-2.1-72}$ & $\frac{1-72}{2-21-72}$ & $\begin{array}{l}\text { Spring } 72 \\
4-24-72\end{array}$ & $\begin{array}{l}\text { Bummer } 72 \\
9-18-72\end{array}$ \\
\hline \multicolumn{8}{|l|}{ Isotopic Ratios: } \\
\hline${ }^{18} 0 /{ }^{16} 0^{\alpha}$ & -4.46 & -4.46 & -4.50 & -4.50 & & & \\
\hline${ }^{2} H i /{ }^{1} H^{\alpha}$ & -24.1 & -22.9 & -24.3 & -24.5 & & & \\
\hline \multicolumn{8}{|l|}{${ }^{34} \mathrm{~S} /{ }^{32} \mathrm{~S}$} \\
\hline \multicolumn{8}{|c|}{ Dissolved Gases, mol $\%:^{b}$} \\
\hline $\mathrm{O}_{2}, \mathrm{ppm}$ & 8.0 & & & & & & \\
\hline $\mathrm{CO}_{2}, \mathrm{pPm}$ & 34.7 & 35.9 & & 38 & & & \\
\hline \multicolumn{8}{|l|}{$\mathrm{N}_{2}$} \\
\hline A & & & & & & $\therefore$ & \\
\hline \multicolumn{8}{|l|}{$\mathrm{CH}_{4}$} \\
\hline \multicolumn{8}{|l|}{$\mathrm{H}_{2}$} \\
\hline $\mathrm{He}$ & & & & & & ⿶ & \\
\hline \multicolumn{8}{|c|}{ Dissolved Solids, mg/l: } \\
\hline & $b$ & $b$ & $b$ & $b$ & $c$ & $c$ & $c$ \\
\hline $\mathrm{SiO}_{2}$ & 9.45 & 0.42 & 1.18 & 0.70 & 0.60 & & \\
\hline $\mathrm{Fe}$ & $<0.05$ & 0.08 & $<0.05$ & $<0.05$ & 0.012 & 0.35 & $<0.2$ \\
\hline$M_{n}$ & $<0.05$ & $<0.05$ & $<0.05$ & $<0.05$ & $<0.05$ & & \\
\hline $\mathrm{Cu}$ & 0.02 & 0.07 & 0.03 & 0.23 & & & \\
\hline $\mathrm{Mg}$ & 22.5 & 8.0 & 16.9 & 9.2 & 9.2 & 0.37 & 0.3 \\
\hline $\mathrm{Ca}$ & 18.1 & 5.6 & 1.7 & 7.0 & 7.0 & 5.9 & 2.1 \\
\hline $\mathrm{Na}$ & 5.6 & 5.9 & 1.83 & 12.5 & 12.5 & .2 .1 & 2.1 \\
\hline$k$ & 0.75 & 0.60 & 0.40 & 1.0 & 0.90 & 0.50 & 0.4 \\
\hline $\mathrm{HCO}_{3}$ & 33.4 & 35.0 & 14.2 & 33.3 & 27.5 & 25.3 & 24 \\
\hline $\mathrm{SO}_{4}$ & $<2$ & 4.6 & $<2$ & 11.3 & 10.2 & 1.3 & 1.5 \\
\hline $\mathrm{Cl}$ & 1.9 & 1.6 & 1.8 & 1.6 & 1.6 & $<1.5$ & 2.5 \\
\hline $\mathrm{NO}_{3}$ & 1.33 & 0.26 & 0.88 & 0.88 & 0.44 & 2.2 & 0.8 \\
\hline $\mathrm{PO}_{4}$ & 7.0 & 10.3 & 2.8 & 5.6 & 0.18 & & \\
\hline Total (Residue): & 69.0 & 61.4 & 9.8 & 67 & 85.2 & & \\
\hline Hardness as $\mathrm{CaCO}_{3}$ : & 55.2 & 47.0 & 17.9 & 55.1 & 55.1 & & \\
\hline $\mathrm{pH}:$ & 7.0 & 4.8 & 6.5 & 6.65 & 7.0 & 6.4 & 6.5 \\
\hline
\end{tabular}


TABLE 2, Part A, Continued

Source: Well 905-70G, McBean Formation, depth $250 \mathrm{ft}$, ground elevation $392 \mathrm{ft}$

\begin{tabular}{|c|c|c|c|c|c|c|c|c|}
\hline Date Sampled: & $\begin{array}{l}\text { Spring } 72 \\
5-21-71\end{array}$ & $\begin{array}{l}\text { Stumer-71 } \\
8-31-71\end{array}$ & $\begin{array}{l}\text { Fal2 } 71 \\
11-18-71\end{array}$ & $\frac{\text { Winter }}{2-21-72}$ & $\frac{1-72}{2-21-72}$ & & $\begin{array}{l}\text { Spring } 72 \\
5-15-72\end{array}$ & $\begin{array}{l}\text { Summer } 72 \\
9-18-78\end{array}$ \\
\hline \multicolumn{9}{|l|}{ Isotopic Ratios: } \\
\hline${ }^{18} 0 /{ }^{16} \mathrm{o}^{9}$ & -4.92 & -4.84 & -4.74 & -4.74 & & & & \\
\hline${ }^{2} \mathrm{H} /{ }^{1} \mathrm{H}^{a}$ & -25.8 & -25.5 & -25.5 & -25.6 & & & & \\
\hline${ }^{34} \mathrm{~S} /{ }^{32} \mathrm{~S}^{d}$ & & & $8 \pm 2$ & & & & & \\
\hline \multicolumn{9}{|c|}{ Dissolved Gases, mol $::^{b}$} \\
\hline $\mathrm{O}_{2}, \mathrm{ppm}$ & 7.5 & & & & & & & \\
\hline $\mathrm{CO}_{2}, \mathrm{ppm}$ & 2.0 & 2.55 & & 21.0 & & & & \\
\hline \multicolumn{9}{|l|}{$\mathrm{N}_{2}$} \\
\hline \multicolumn{9}{|l|}{ A } \\
\hline \multicolumn{9}{|l|}{$\mathrm{CH}_{4}$} \\
\hline \multicolumn{9}{|l|}{$\mathrm{H}_{2}$} \\
\hline \multicolumn{9}{|l|}{$\mathrm{He}$} \\
\hline \multicolumn{9}{|c|}{ Dissolved Solids, mg/l: } \\
\hline & $b$ & $b$ & $b$ & b & $c$ & & $c$ & c \\
\hline $\mathrm{SiO}_{2}$ & 5.1 & 0.42 & 2.1 & 0.6 & 0.8 & & 4.0 & \\
\hline $\mathrm{Fe}$ & 0.1 & 0.06 & $<0.02$ & 0.05 & 0.006 & & 0.10 & $<0.2$ \\
\hline Mn & $<0.05$ & $<0.05$ & $<0.05$ & $<0.05$ & $<0.05$ & & & \\
\hline $\mathrm{Cu}$ & $<0.05$ & 0.10 & $<0.02$ & 0.16 & 0.12 & & & \\
\hline $\mathrm{Mg}$ & 0.7 & 2.0 & 3.8 & 1.42 & 1.24 & & 0.37 & 0.3 \\
\hline $\mathrm{Ca}$ & 6.4 & 1.2 & 0.3 & 0.22 & 0.15 & & 0.35 & $<0.1$ \\
\hline $\mathrm{Na}$ & 3.3 & 2.2 & 1.6 & 4.3 & 5.5 & & 1.8 & 2.0 \\
\hline k & 0.4 & 0.35 & 0.2 & 0.55 & 0.83 &. & 0.23 & 0.3 \\
\hline $\mathrm{HCO}_{3}$ & 2.0 & & 8.9 & 4.0 & 1.5 & & 0.0 & $<0.1$ \\
\hline $\mathrm{SO}_{4}$ & $<2$ & 0.64 & $<2$ & 0.70 & 1.4 & & $<1$ & $<1$ \\
\hline $\mathrm{C} 1$ & 1.8 & 1.0 & 1.1 & 0.96 & 0.76 & & 2.2 & 2.0 \\
\hline $\mathrm{NO}_{3}$ & 4.4 & 0.62 & 0.52 & 4.4 & 0.27 & & 5.0 & 3.0 \\
\hline $\mathrm{PO}_{4}$ & 0.47 & 0.37 & $<0.3$ & $<0.3$ & 0.3 & & & $<1$ \\
\hline Total (Kesidue): & 11.0 & 5.0 & 10.5 & 3.2 & 31 & & & \\
\hline Hardness as $\mathrm{CaCO}_{3}$ : & 17.3 & 11.2 & 16.7 & 6.4 & 5.5 & & & \\
\hline $\mathrm{pH}:$ & 5.4 & 5.0 & 8.3 & 5.0 & 5.2 & & 5.15 & 5.49 \\
\hline $\begin{array}{l}\text { Specific Con- } \\
\text { ductance, } \mu \text { mhos: }\end{array}$ & 39 & 20 & 19 & 23 & 21 & & & \\
\hline
\end{tabular}


TABLE 2

Analyses of Water from Coastal Plain Formations

Part B. Single Analyses

\begin{tabular}{|c|c|c|c|c|c|c|}
\hline $\begin{array}{l}\text { Well No.: } \\
\text { Stratum: }\end{array}$ & $\begin{array}{l}\text { DRB } 4 \mathrm{WW} \\
\text { McBean }\end{array}$ & $\begin{array}{l}\text { DRB } 6 W W \\
\text { Congaree }\end{array}$ & $13 G$ & \multicolumn{2}{|c|}{$\begin{array}{l}54 P \\
\text { Tuscaloosa }\end{array}$} & $55 R$ \\
\hline Date Sampled: & $5-20-71$ & $5-20-71$ & $4-11-6 ?$ & \multicolumn{2}{|l|}{$7-12-68$} & $10-27-64$ \\
\hline \multicolumn{7}{|l|}{ Isotopic Ratios: } \\
\hline${ }^{10} \mathrm{O} /{ }^{16} \mathrm{O}^{a}$ & -4.37 & -4.22 & & & & \\
\hline${ }^{2} \mathrm{H} /{ }^{1} \mathrm{H}$ & - & - & & & & \\
\hline${ }^{34} \mathrm{~s} /{ }^{32} \mathrm{~s}^{d}$ & 23.0 & -22.2 & & & & \\
\hline \multicolumn{7}{|l|}{$\begin{array}{l}\text { Dissolved Gases, mol }: b \\
\mathrm{O}_{2}, \mathrm{ppm}\end{array}$} \\
\hline $\mathrm{CO}_{2}$, ppm & 3.9 & $<0.005$ & & & & \\
\hline \multicolumn{7}{|l|}{$\mathrm{N}_{2}$} \\
\hline \multicolumn{7}{|l|}{ A } \\
\hline \multicolumn{7}{|l|}{$\mathrm{CH}_{4}$} \\
\hline \multicolumn{7}{|l|}{$\mathrm{H}_{2}$} \\
\hline \multicolumn{7}{|l|}{$\mathrm{He}$} \\
\hline \multicolumn{7}{|l|}{ Dissolved Solids, mg/l: } \\
\hline & $b$ & $b$ & $b$ & $b$ & 4 & t. \\
\hline $\mathrm{SiO}_{2}$ & 1.3 & $<0.08$ & & 12 & & 11 \\
\hline $\mathrm{Fe}$ & $<0.05$ & $<0.05$ & 0.2 & 0.18 & & $<0.05$ \\
\hline Mn & $<0.05$ & $<0.05$ & & $<0.05$ & & $<0.05$ \\
\hline $\mathrm{Cu}$ & - & - & $<0.02$ & 0.06 & & 0.03 \\
\hline $\mathrm{Mg}$ & 217 & 2.0 & 1.2 & 0.9 & & 5.0 \\
\hline $\mathrm{Ca}$ & 19.7 & 1.6 & 5.3 & 5.0 & & 7.0 \\
\hline $\mathrm{Na}$ & 230 & 100 & 5.6 & 1.2 & & 0.6 \\
\hline K & 1.3 & 15 & 3.4 & 1.0 & & 1.2 \\
\hline $\mathrm{HCO}_{3}$ & 25.8 & 2.3 & 18 & 10.5 & & 15 \\
\hline $\mathrm{SO}_{4}$ & 24.7 & 2.0 & 14 & 14.1 & $\therefore$ & 10 \\
\hline $\mathrm{C} 1$ & 103 & 7.5 & 0.8 & 1.4 & & 3.2 \\
\hline $\mathrm{NO}_{3}$ & 0.13 & 0.09 & & 0.27 & & - \\
\hline $\mathrm{PO}_{4}$ & 0.2 & $<0.3$ & 0.3 & 1.8 & & 0.2 \\
\hline F & 0.3 & 5.0 & - & - & & \\
\hline Total (Residue): & 91 & 98 & 45 & 38 & & 36 \\
\hline Hardness as $\mathrm{CaCO}_{3}$ : & 55 & 4.8 & 18 & 16 & & 38 \\
\hline $\mathrm{pH}:$ & 7.8 & 8.3 & 6.6 & 6.3 & & 5.8 \\
\hline $\begin{array}{l}\text { Specific Conductance, } \\
\text { umhos: }\end{array}$ & 110 & 150 & 57 & 40 & & 60 \\
\hline \multicolumn{7}{|l|}{ Remarks: } \\
\hline $\begin{array}{l}\text { Well depth, ft } \\
\text { Ground elevation, ft } \\
\text { Screen depths, ft }\end{array}$ & $\begin{aligned} & 198 \\
&+ 246 \\
& \text { bottom }\end{aligned}$ & $\begin{aligned} & 241 \\
+ & 271 \\
& 236-241\end{aligned}$ & & & & \\
\hline Samp ler: & cable & cable & & & & \\
\hline
\end{tabular}

Analysts (see text): $a$, Scripps; $b$, SRP; $c$, SRL; $d$, ANL; $e$, Bu Mines; $f$, USGS; $g$, Geochron. 
TABLE 3

Analyses of Water from Crystalline Metamorphic Rock

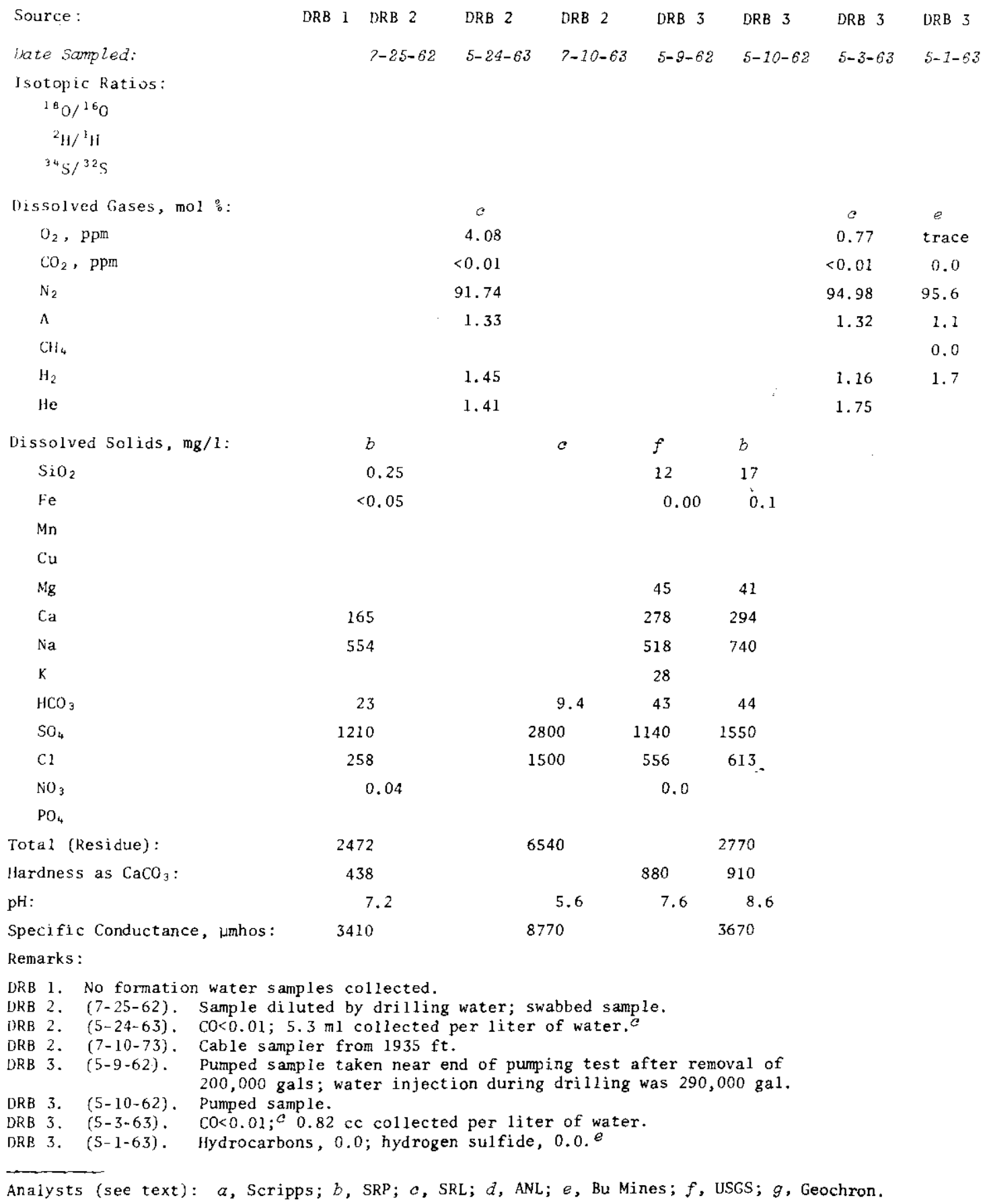

Analysts (see text): $a$, Scripps; $b, \operatorname{SRP} ; c$, SRL; $d$, ANL; $e$, Bu Mines; $f$, USGS; $g$, Geochron. 
TABLE 3, Continued

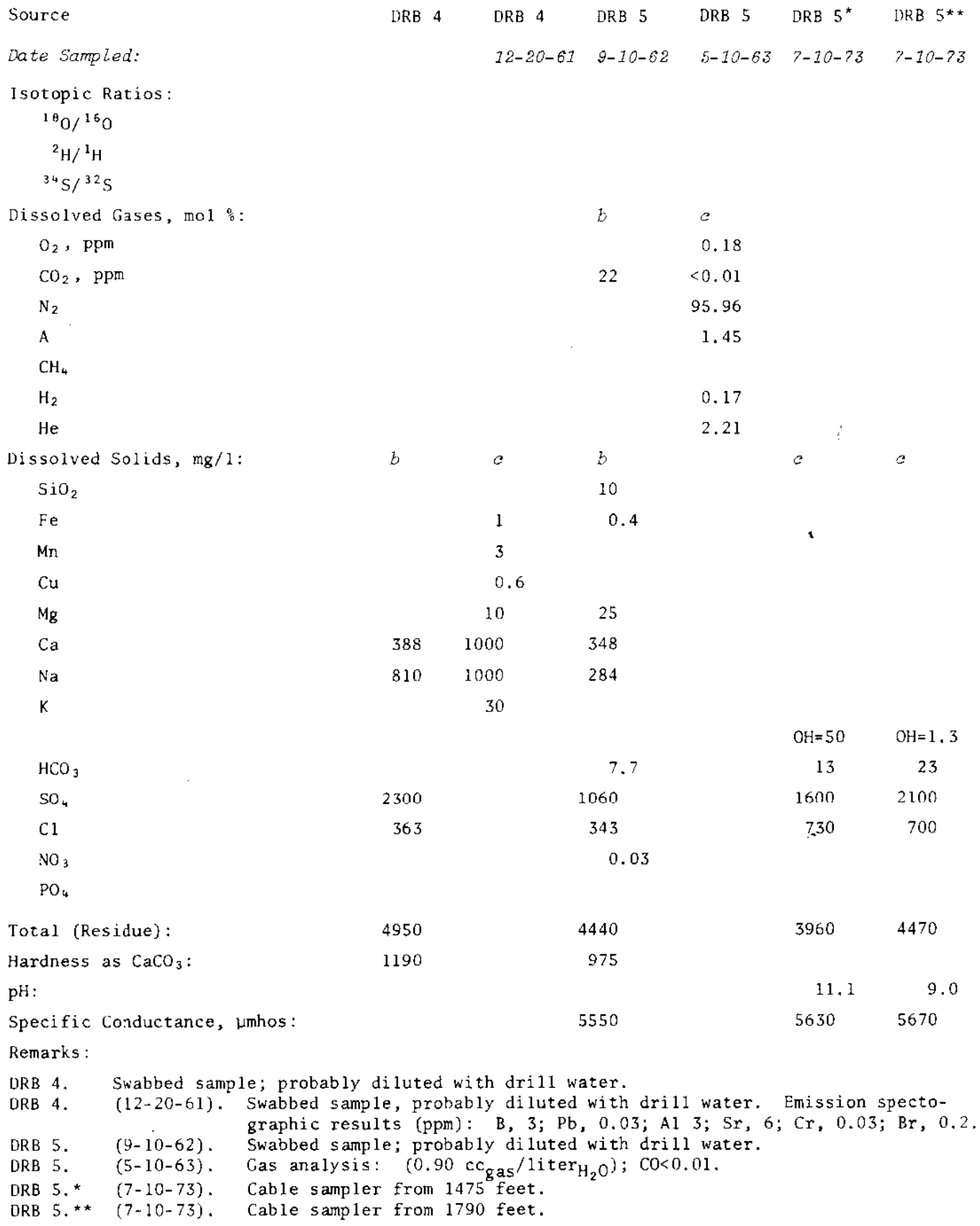


TABLE 3, Continued

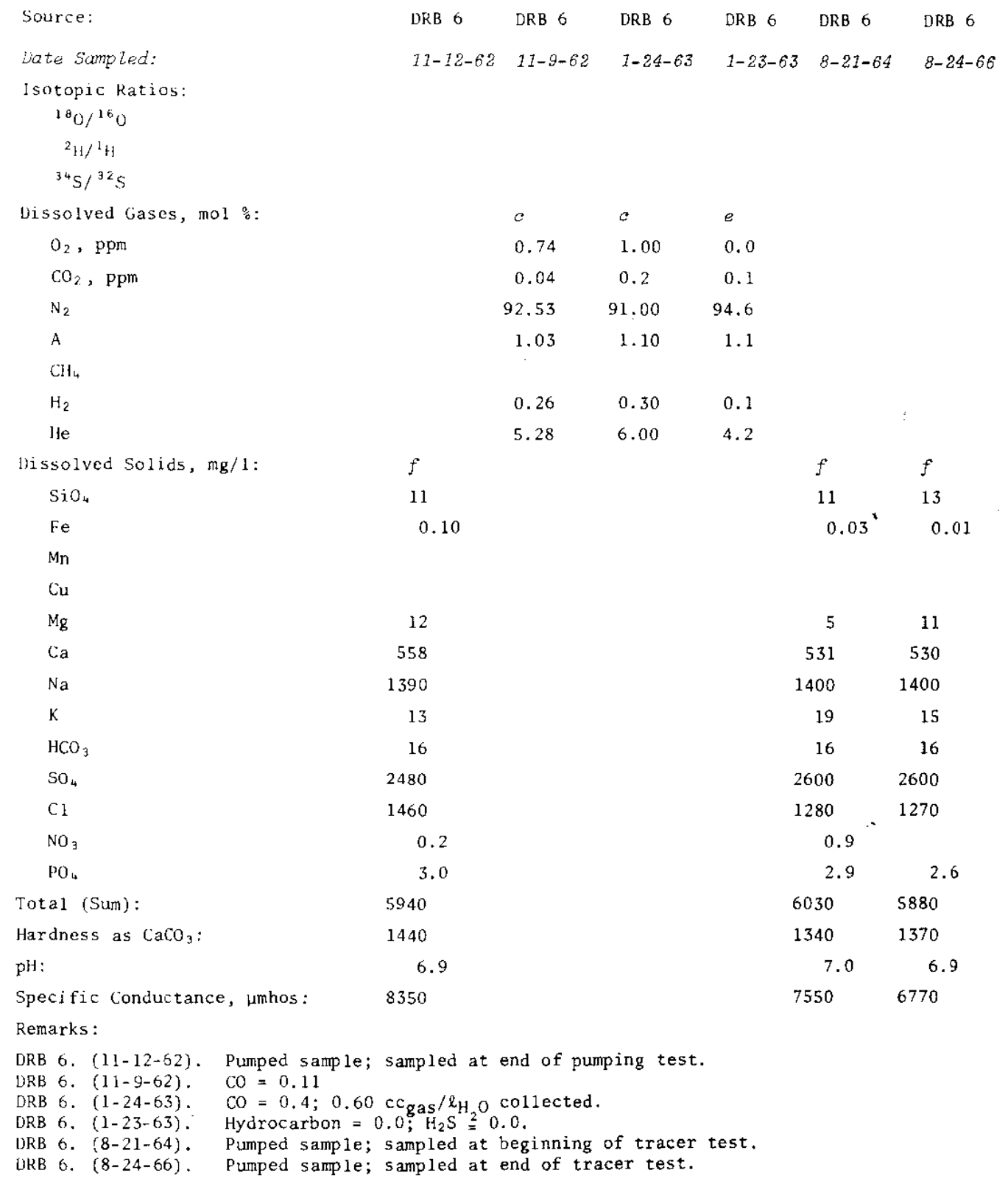




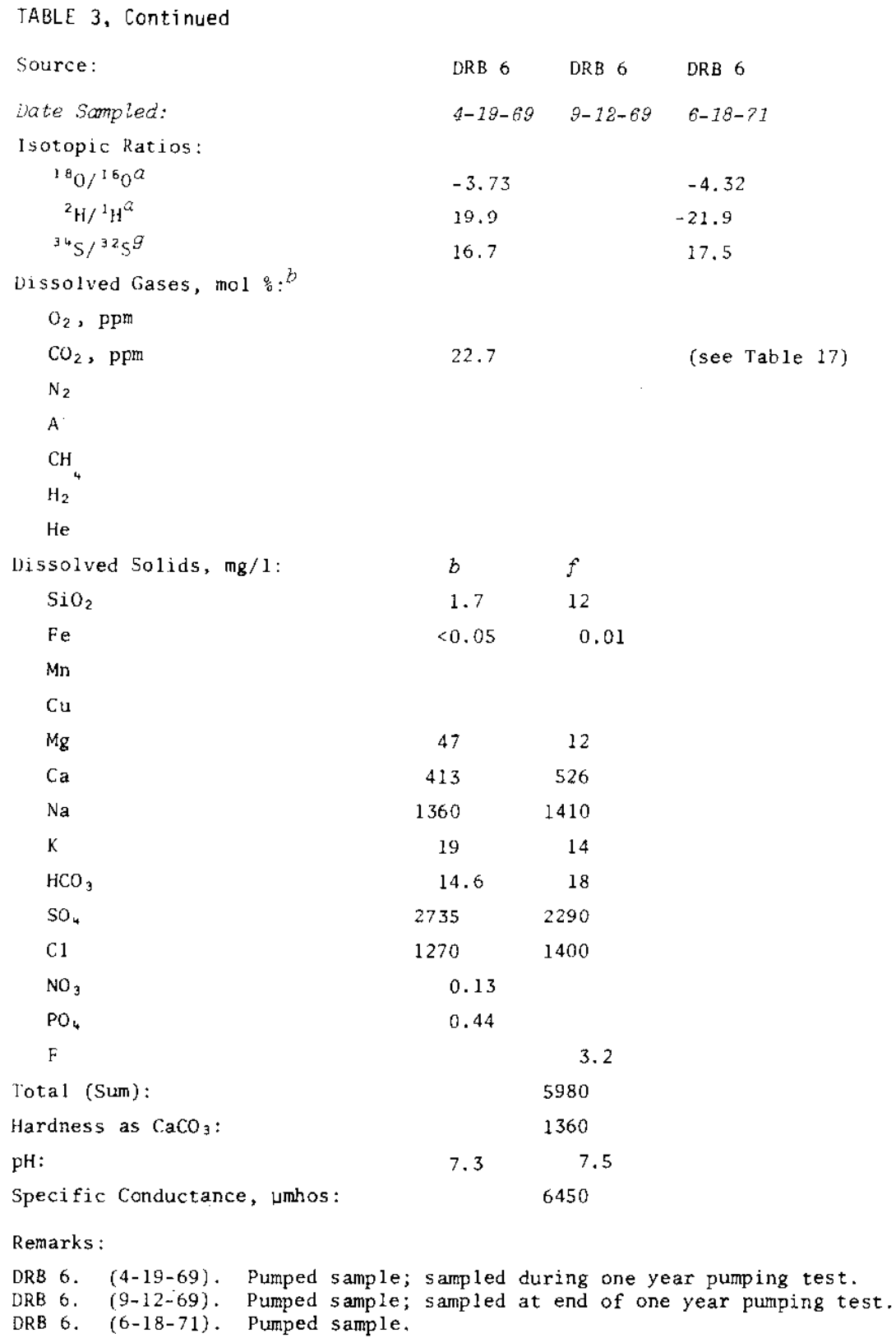


TABLE 3, Continued

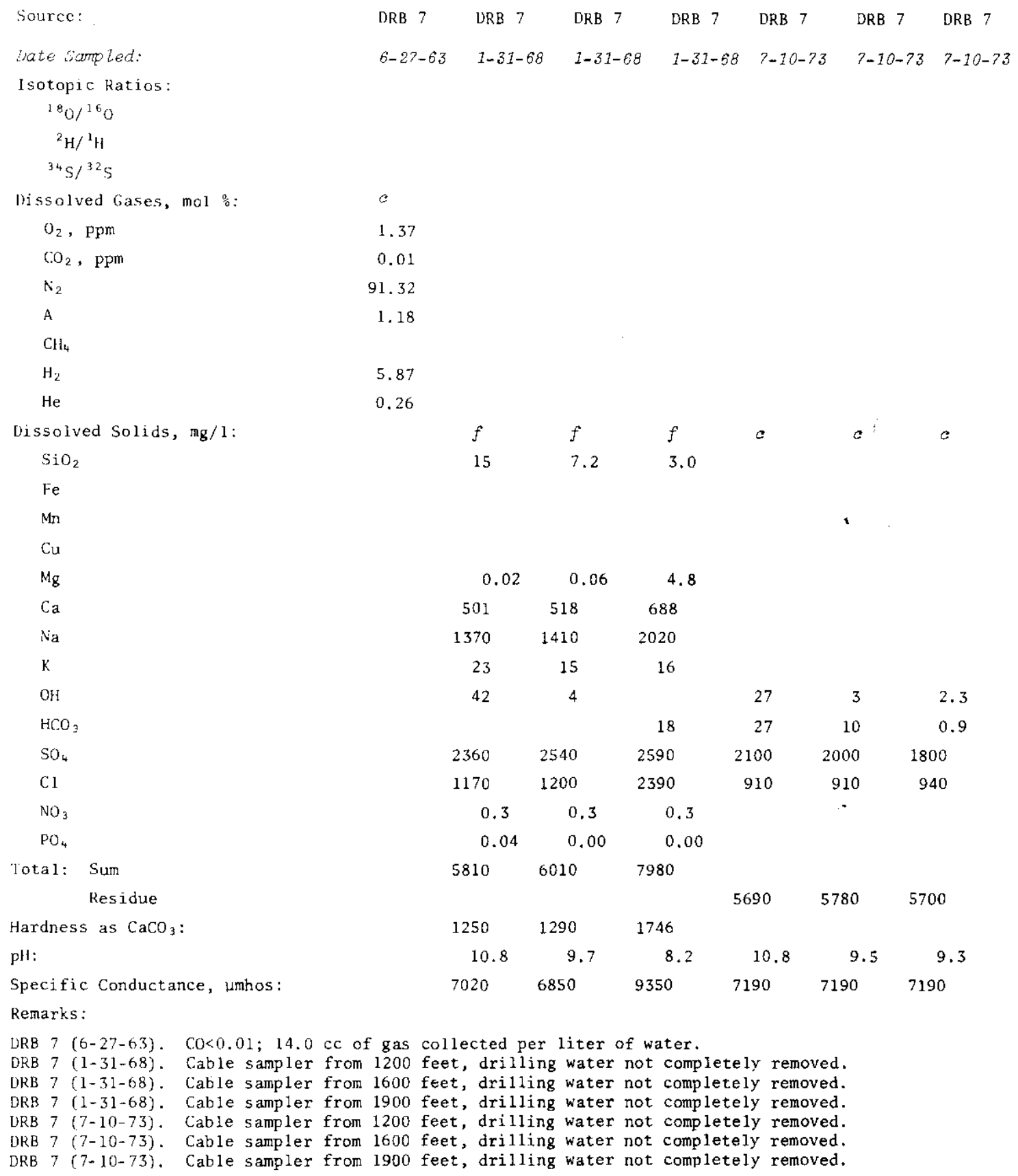


TABLE 3, Continued

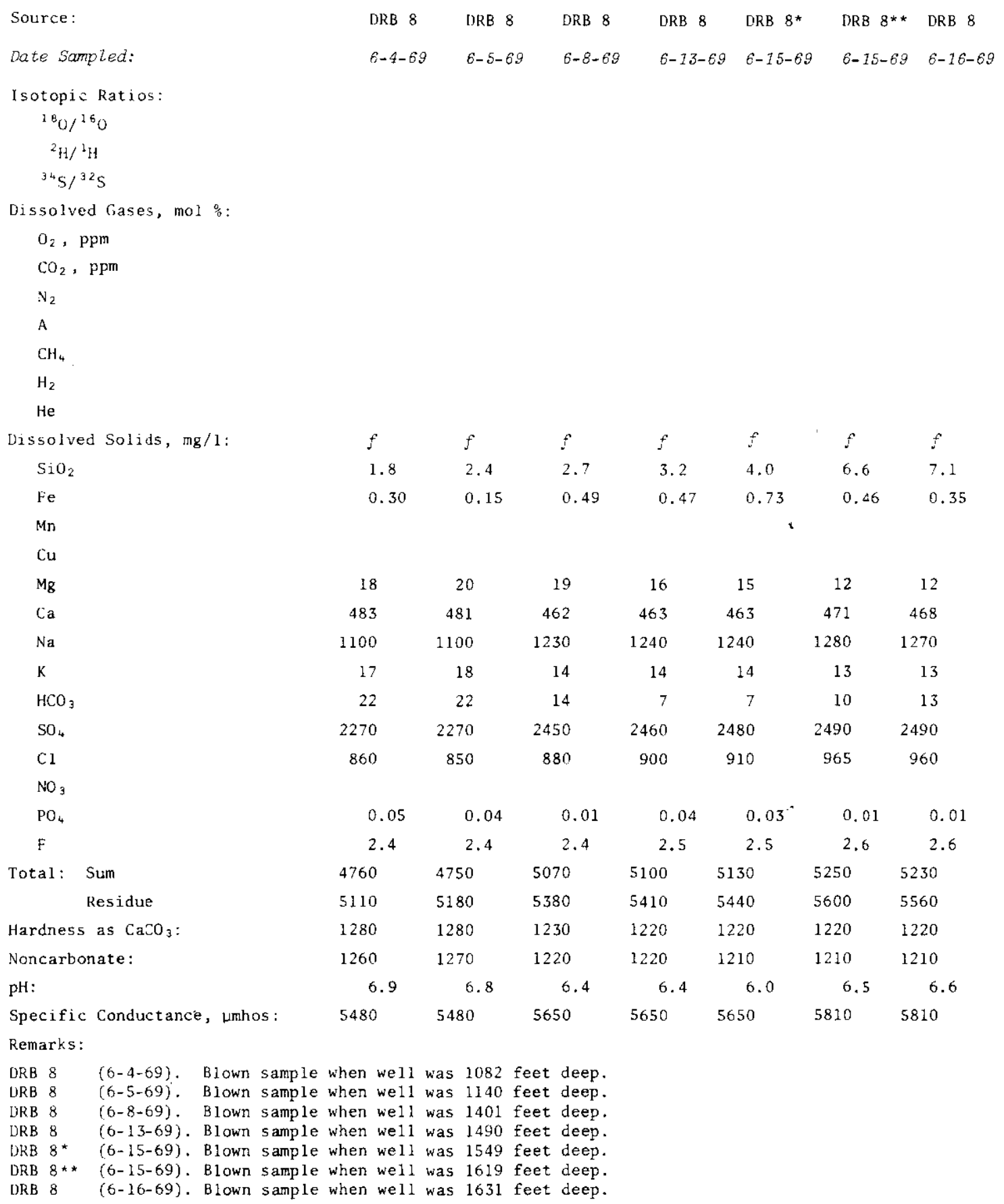


TABLE 3, Continued

\begin{tabular}{|c|c|c|c|}
\hline Source: & DRB 8 & DRB 8 & DRB 8 \\
\hline vate Sampled: & $7-21-$ & $10-10-$ & $.70 \quad 10-1-70$ \\
\hline \multicolumn{4}{|l|}{ Isotopic Ratios: } \\
\hline${ }^{18} 0 /{ }^{16} 0^{a}$ & & & -4.71 \\
\hline${ }^{2} \mathrm{H} /{ }^{1} \mathrm{H}^{a}$ & & & -22.7 \\
\hline${ }^{34} \mathrm{~S} /{ }^{32} \mathrm{~S}^{9}$ & & & 10.8 \\
\hline Dissolved Gases, mol $: b$ & & - & \\
\hline $\mathrm{O}_{2}, \mathrm{ppm}$ & & $<0.02$ & 1.5 \\
\hline \multicolumn{4}{|l|}{$\mathrm{CO}_{2}, \mathrm{ppm}$} \\
\hline \multicolumn{4}{|l|}{$N$} \\
\hline \multicolumn{4}{|l|}{ A } \\
\hline \multicolumn{4}{|l|}{$\mathrm{CH}_{4}$} \\
\hline \multicolumn{4}{|l|}{$\mathrm{H}_{2}$} \\
\hline \multicolumn{4}{|l|}{$\mathrm{He}$} \\
\hline Dissolved Solids, mg/l & $f$ & $f$ & $b$ \\
\hline $\mathrm{SiO}_{2}$ & 7.6 & 7.0 & 0.7 \\
\hline $\mathrm{Fe}$ & 0.033 & & $<0.05$ \\
\hline $\mathrm{Mn}$ & 0.130 & & $<0.05$ \\
\hline \multicolumn{4}{|l|}{$\mathrm{Cu}$} \\
\hline $\mathrm{Mg}$ & 15 & 12 & 830 \\
\hline $\mathrm{Ca}$ & 467 & 473 & 640 \\
\hline $\mathrm{Na}$ & 1200 & 1180 & 680 \\
\hline K & 16 & 15 & 15 \\
\hline $\mathrm{HCO}_{3}$ & 18 & 10 & 3.7 \\
\hline $\mathrm{SO}_{4}$ & 2590 & 2580 & 3530 \\
\hline $\mathrm{Cl}$ & 900 & 829 & 780 \\
\hline $\mathrm{NO}_{3}$ & 0.2 & 0.3 & 0.13 \\
\hline $\mathrm{PO}_{4}$ & & & 0.18 \\
\hline $\mathrm{F}$ & 3.1 & 3.7 & 2.6 \\
\hline \multirow{2}{*}{$\begin{array}{ll}\text { Total: } & \text { Sum } \\
& \text { Residue }\end{array}$} & 5200 & 5110 & 5160 \\
\hline & 5600 & 5330 & \\
\hline Hardness as $\mathrm{CaCO}_{3}$ : & 1220 & 1230 & 2000 \\
\hline Noncarbonate: & 1210 & 1210 & \\
\hline $\mathrm{pH}:$ & 6.7 & 9.2 & 7.5 \\
\hline $\begin{array}{l}\text { Specific Conductance, Hmhos: } \\
\text { Remarks: }\end{array}$ & 7880 & 6840 & 4500 \\
\hline $\begin{array}{lll}\text { DRB 8. } & (6-21-70) . & \text { Pumped } s \\
\text { DRB 8. } & (10-1-70) . & \text { Pumped } s\end{array}$ & ; Al, 0.0 & $4 \mathrm{mg} / 1$. & \\
\hline
\end{tabular}

- 69 - 
TABLE 3, Continued

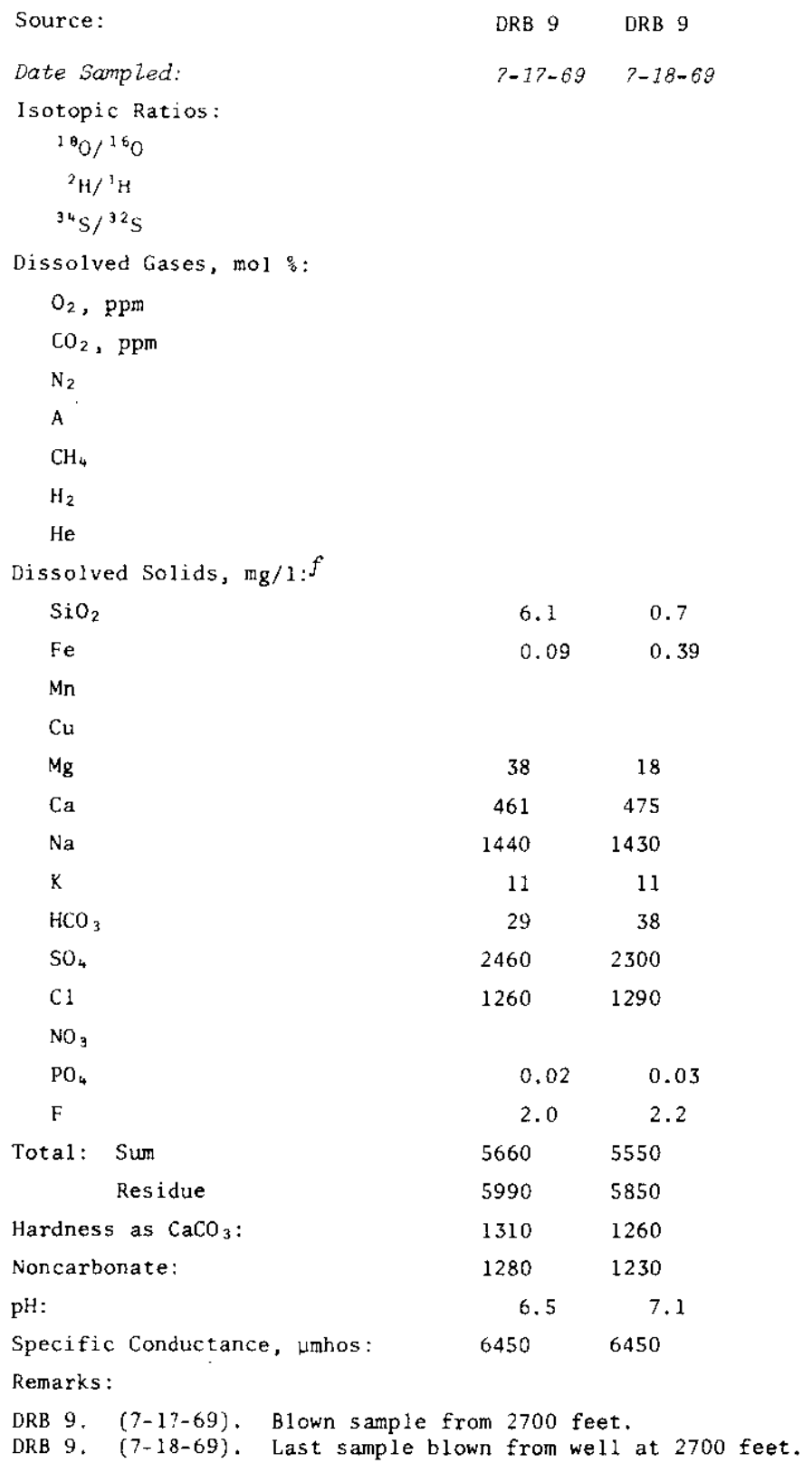


TABLE 3, Continued

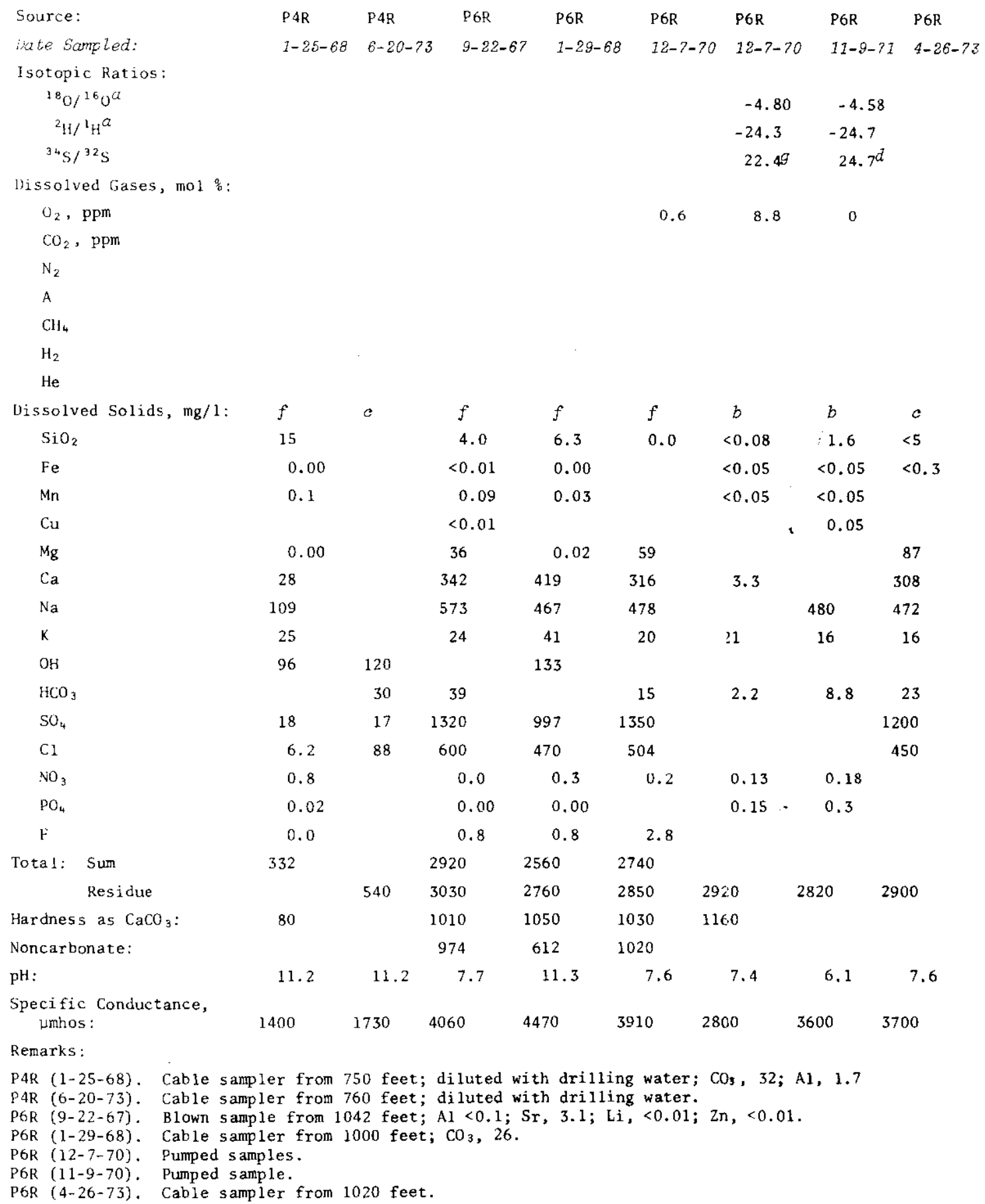


TABLE 3, Continued

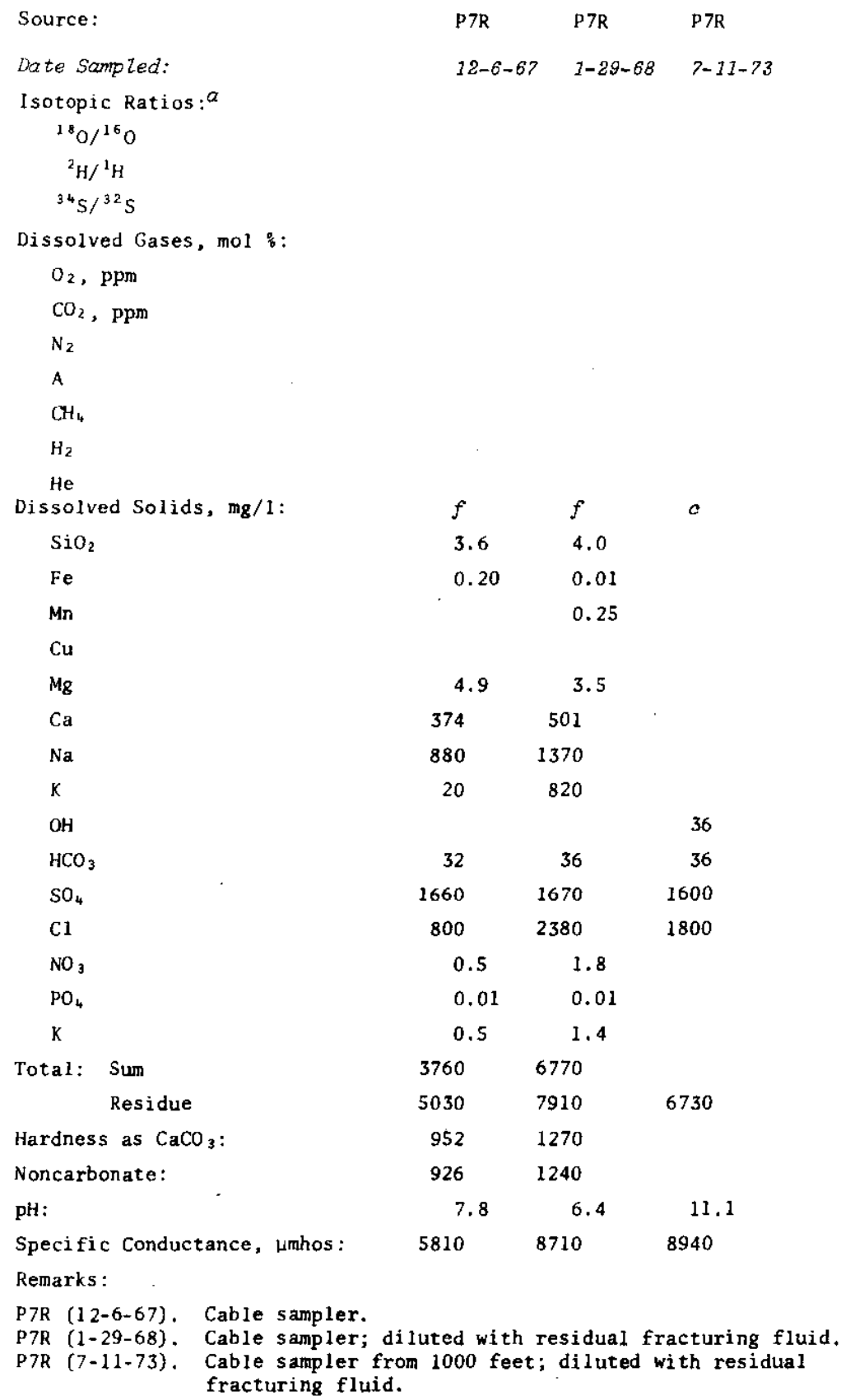

36

$\begin{array}{lll}32 & 36 & 36\end{array}$

$1660 \quad 1670 \quad 1600$

$800 \quad 2380 \quad 1800$

$0.5 \quad 1.8$

$0.01 \quad 0.01$

$0.5 \quad 1.4$

$3760 \quad 6770$

$5030 \quad 7910 \quad 6730$

$952 \quad 1270$

$926 \quad 1240$

$\begin{array}{lll}7.8 & 6.4 & 11.1\end{array}$

5810
8710 8940 
TABLE 3, Continued

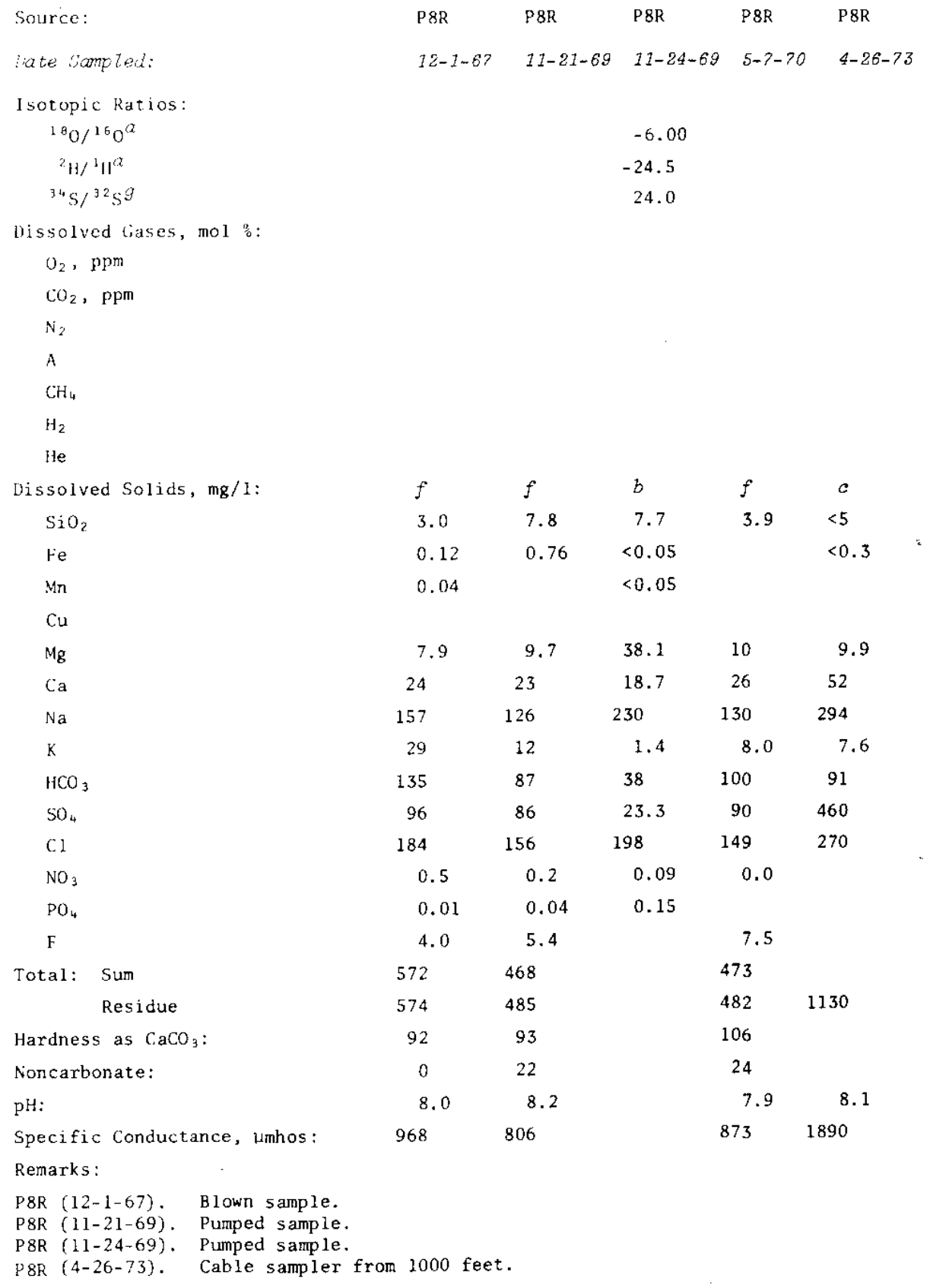


TABLE 3, Continued

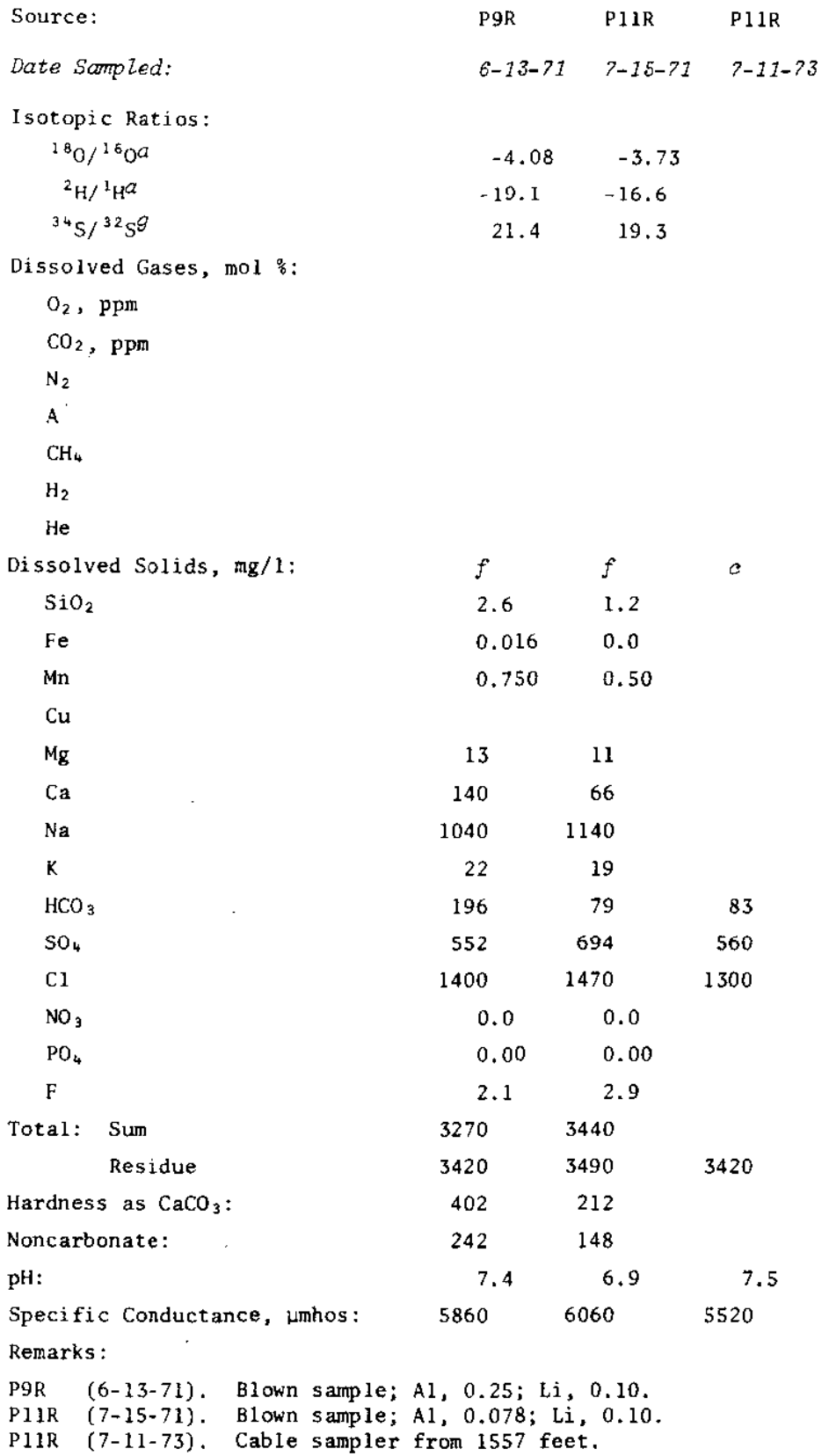


TABLE 4

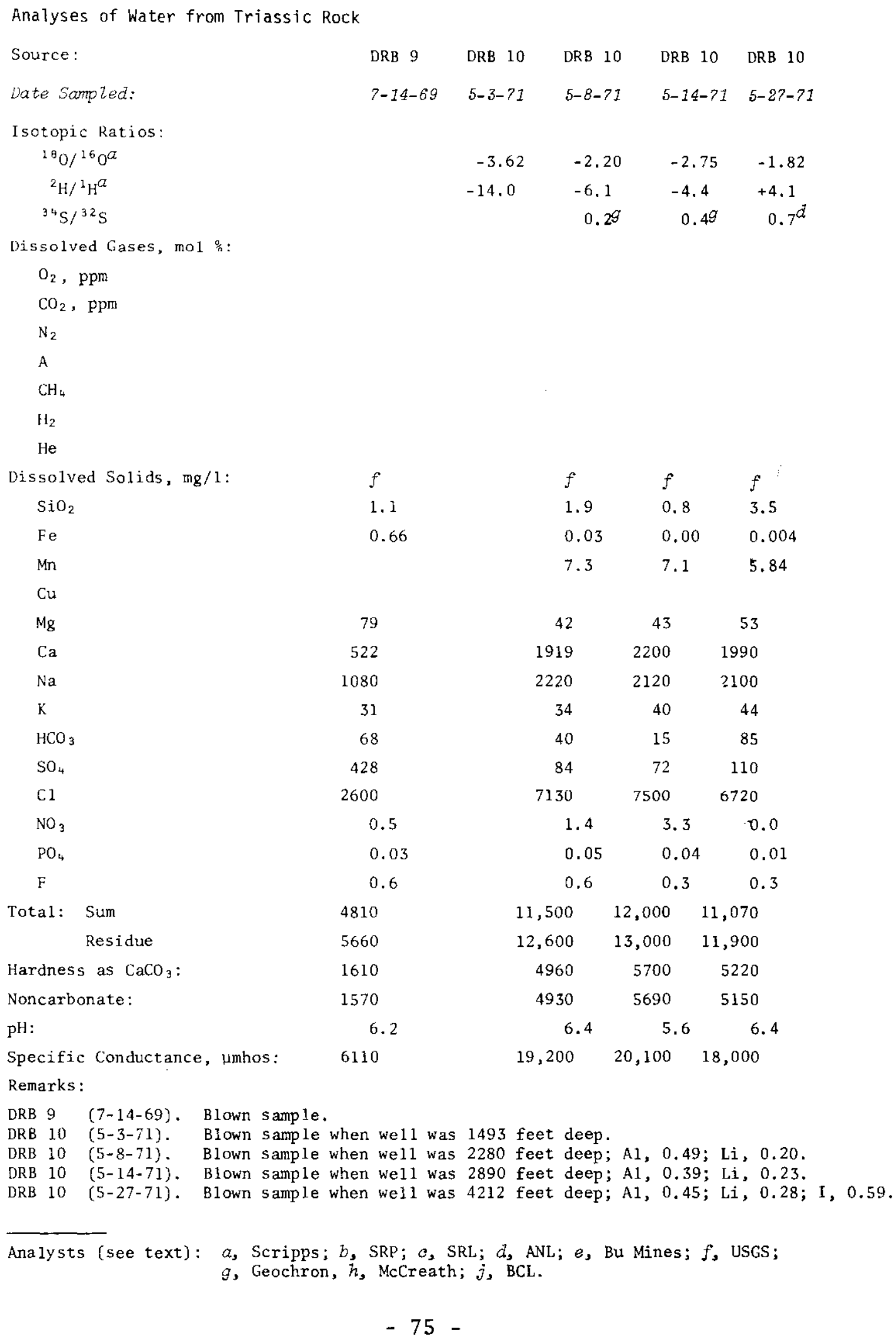

Analysts (see text): $a$, Scripps; $b$, SRP; $c$, SRL; $d$, ANL; $e$, Bu Mines; $f$, USGS; $g$, Geochron, $h$, McCreath; $j$, BCL. 
TABLE 4, Continued

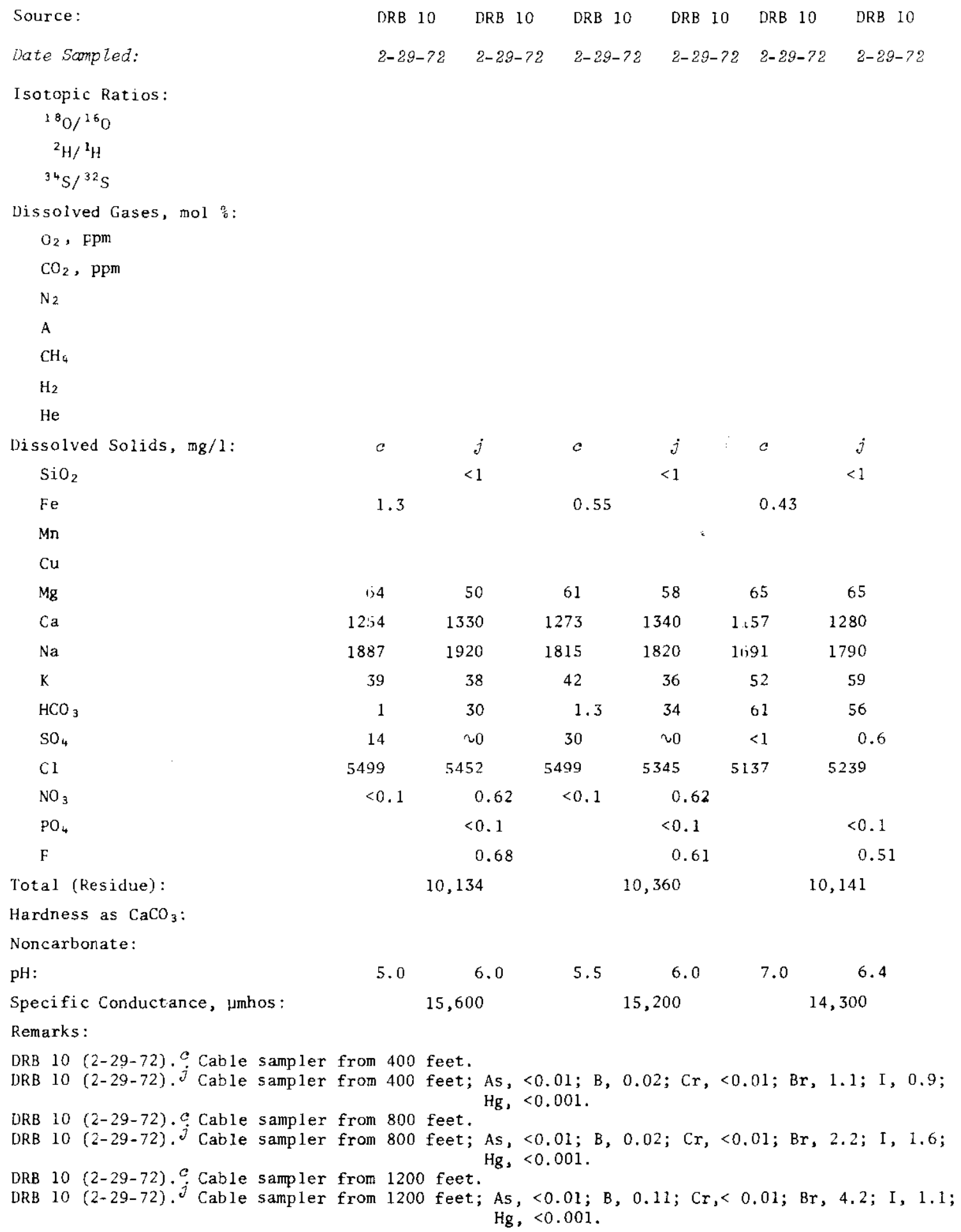


TABLE 4, Continued

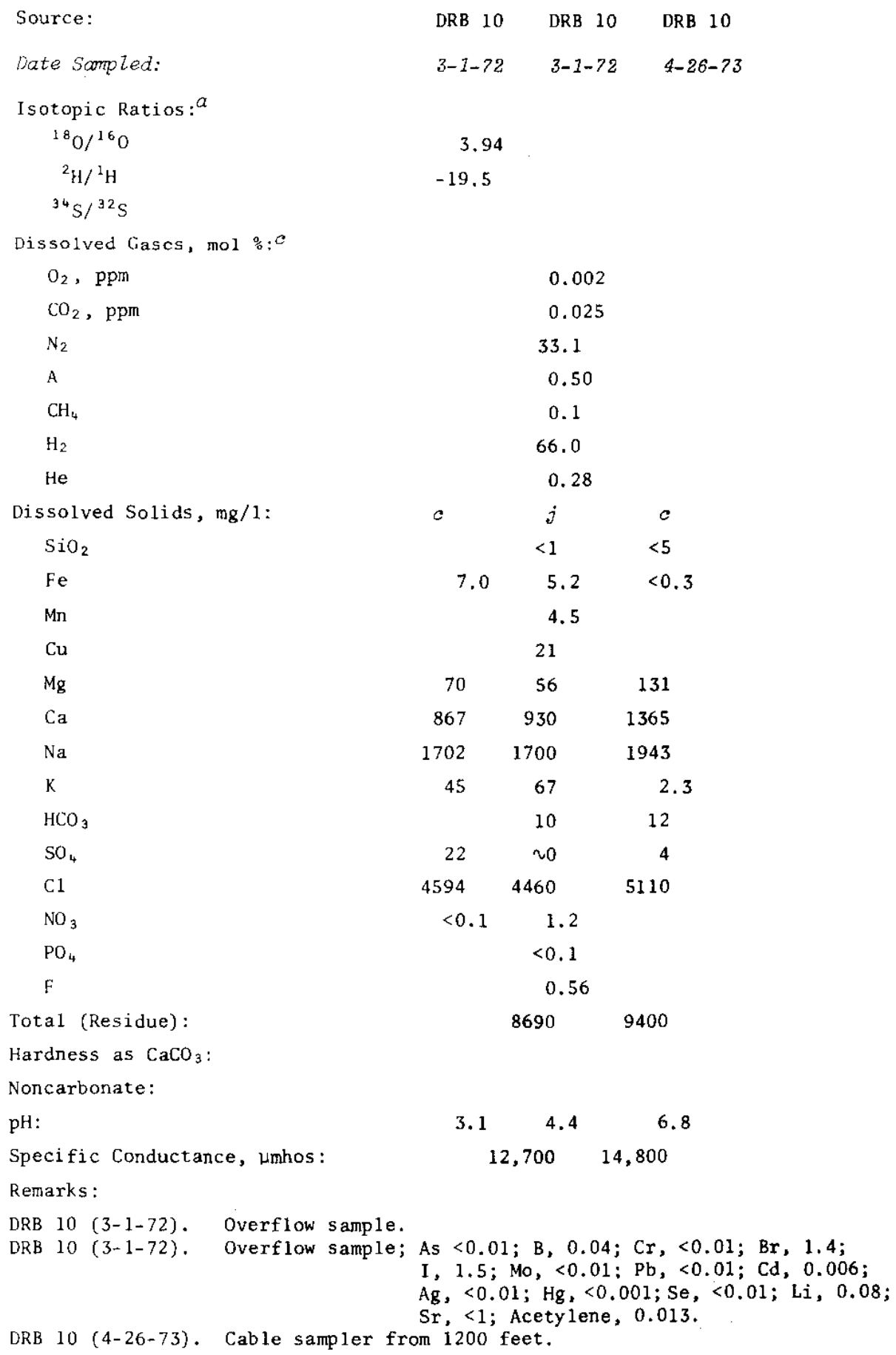


TABLE 4, Continued

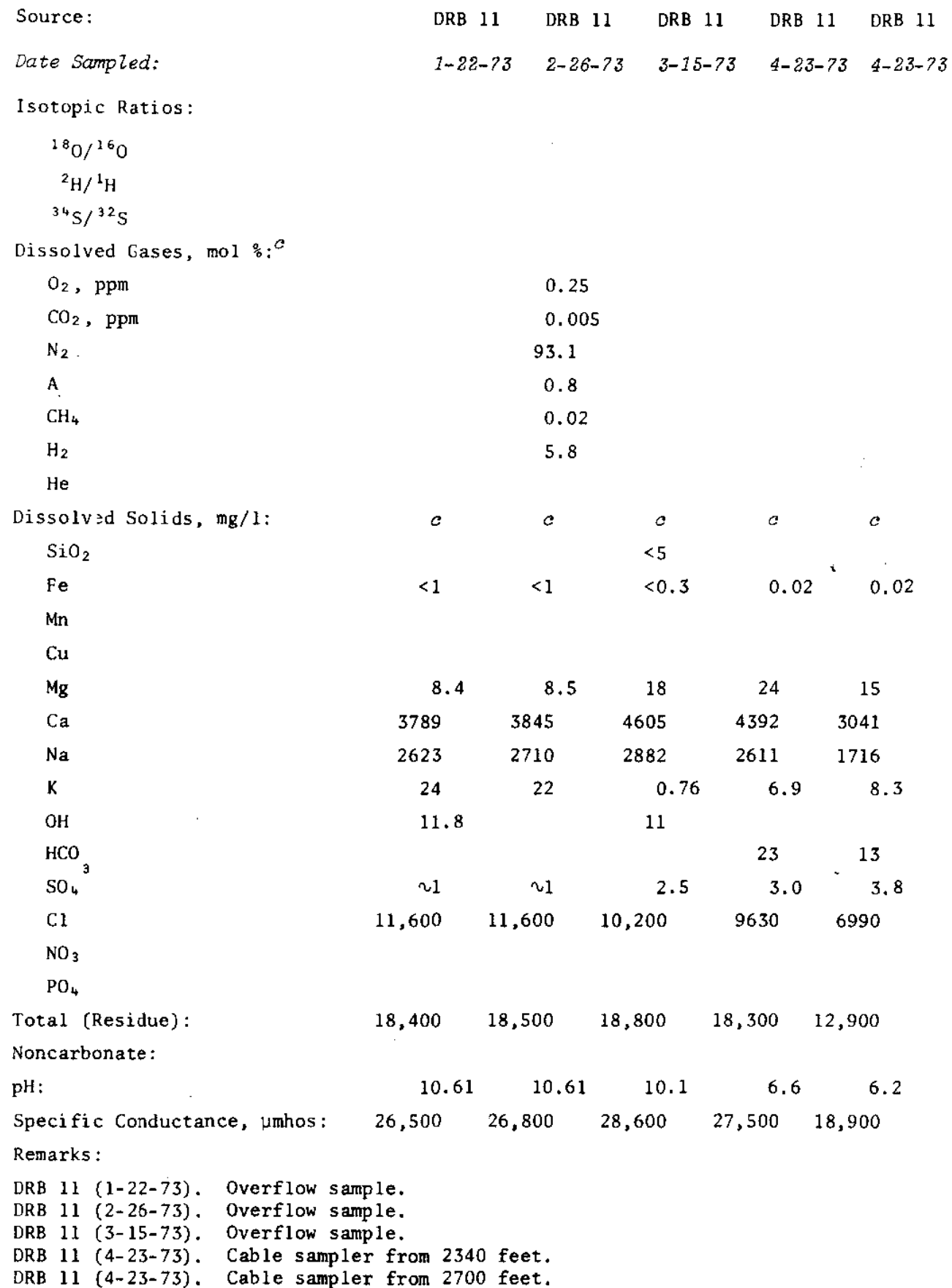


TABLE 4, Continled

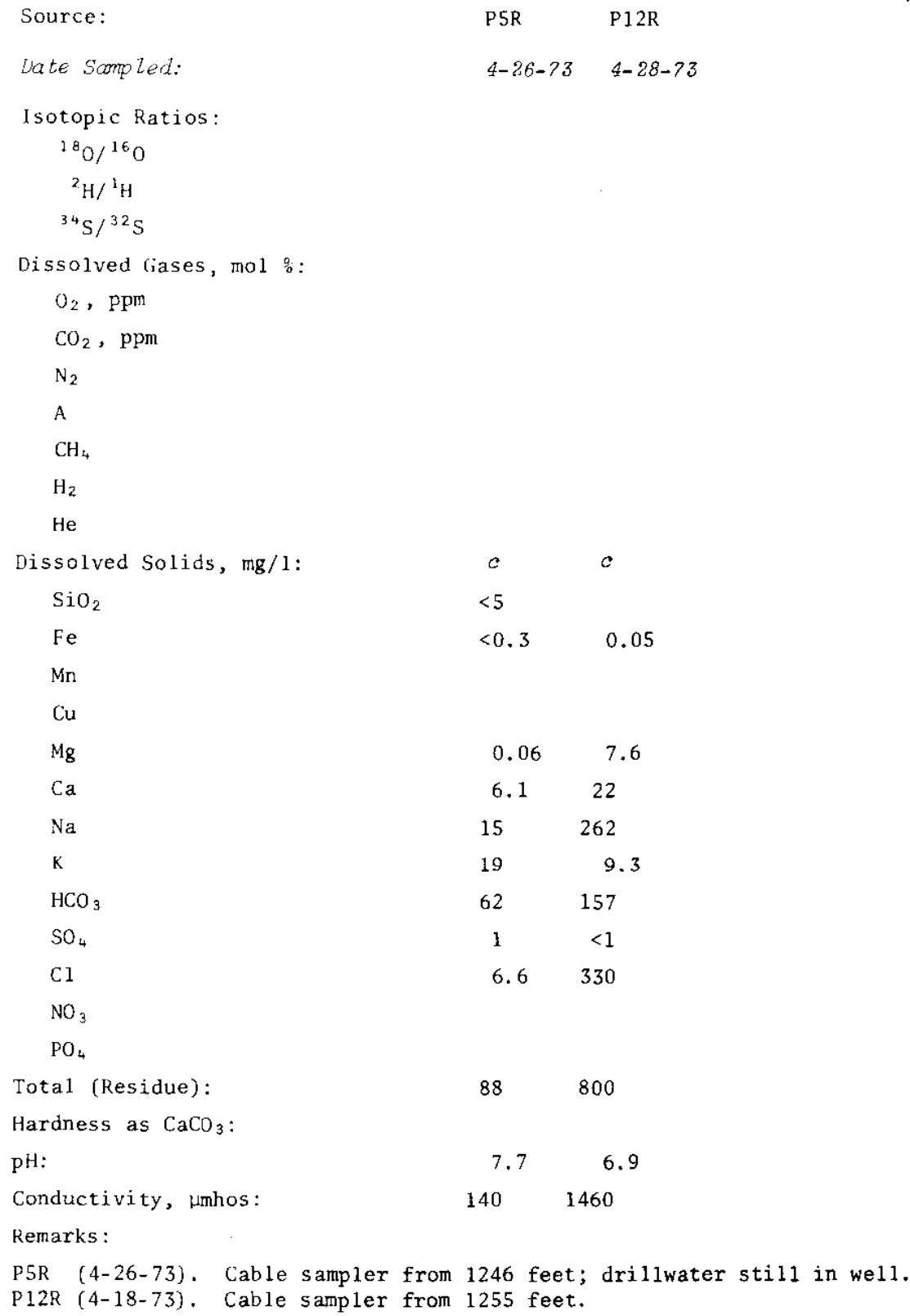


TABLE 5 .

Analyses of Saprolite and Crystalline Metamorphic Rock*

A. Chemical Analysis

\begin{tabular}{|c|c|c|c|c|c|c|c|c|c|c|c|c|c|c|c|c|c|c|c|}
\hline & & & & & & & & & & & & & & & & & & & \\
\hline wezl & $\begin{array}{l}\text { Depth, } \\
\text { ft }\end{array}$ & Description & $\mathrm{SiO}_{2}$ & $\mathrm{Al}_{2} \mathrm{O}_{3}$ & $\mathrm{Fe}_{2} \mathrm{O}_{3}$ & $\mathrm{FeO}$ & $\mathrm{MgO}$ & $\mathrm{CaO}$ & $\mathrm{Na}_{2} \mathrm{O}$ & $\mathrm{K}_{2} \mathrm{O}$ & $\mathrm{H}_{2} \mathrm{O}-$ & $\mathrm{H}_{2} \mathrm{O}+$ & $\mathrm{TiO}_{2}$ & $\mathrm{P}_{2} \mathrm{O}_{5}$ & Ano & $\mathrm{CO}_{2}$ & $\begin{array}{l}\mathrm{Sa}_{\varepsilon} \\
\mathrm{SO}_{2}\end{array}$ & $C 1$ & Sum \\
\hline$P 6 R$ & 773 & Saprolite, unit 1 & 64.5 & 17.0 & 9.0 & 0.12 & 0.20 & 0.30 & 0.10 & 0.30 & 0.92 & 6.7 & 0.75 & 0.02 & 0.05 & $<0.05$ & - & 0.018 & 100 \\
\hline & 782 & Saprolite, unit 2 & 76.0 & 14.0 & 1.9 & 0.12 & 0.10 & 0.30 & 0.20 & 1.4 & 0.60 & 4.2 & 0.38 & 0.04 & 0.05 & $<0.05$ & - & 0.010 & 99 \\
\hline & 830 & Saprolite, unit 4 & 63.0 & 14.1 & 7.5 & 0.78 & 1.1 & 1.3 & 1.7 & 1.1 & 4.9 & 3.3 & 0.64 & 0.09 & 0.12 & $<0.05$ & - & 0.006 & 100 \\
\hline & 859 & $\begin{array}{l}\text { Unweathered horn- } \\
\text { blende - chlorite } \\
\text { schist }\end{array}$ & 50.1 & 15.3 & 3.1 & 5.5 & 3.6 & 7.3 & 3.5 & 1.0 & 0.59 & 2.8 & 1.0 & 0.20 & 0.32 & 4.4 & 1.2 & 0.023 & 100 \\
\hline DRB 1 & 1631.7 & Hornblende schist & 52.0 & 15.6 & 4.8 & 7.5 & 4.8 & 7.7 & 2.6 & 0.40 & 0.05 & 1.4 & 1.2 & 0.15 & 0.20 & $<0.05$ & 0.63 & 0.026 & 99 \\
\hline DRB 2 & 1395 & Hornblende $s$ chist & 43.2 & 16.8 & 3.2 & 9.2 & 9.4 & 7.9 & 1.6 & 1.4 & 0.16 & 4.0 & 0.85 & 0.16 & 0.20 & 1.2 & $<0.05$ & 0.023 & 99 \\
\hline $\mathrm{DRB} 1$ & 1746.8 & $\begin{array}{l}\text { Banded granitoid } \\
\text { gneiss and horn- } \\
\text { blende gneiss }\end{array}$ & 60.6 & 16.4 & 3.1 & 4.2 & 3.4 & 5.6 & 3.5 & 0.50 & 0.05 & 1.4 & 0.80 & 0.12 & 0.15 & 0.09 & - & 0.012 & 100 \\
\hline DRB 7 & 1743 & $\begin{array}{l}\text { Banded hornblende- } \\
\text { chlorite schist } \\
\text { and quartz - feld- } \\
\text { spar gneiss }\end{array}$ & 60.6 & 14.8 & 1.8 & 3.9 & 2.6 & 4.9 & 3.7 & 1,9 & 0.05 & 1.4 & 0.66 & 0.21 & 0.18 & 2.5 & - & 0.015 & 99 \\
\hline DRB 8 & 903 & Saprolite, unit l & 64.9 & 21.2 & 2.8 & 0.31 & 0.38 & 0.25 & 0.18 & 1.9 & & & 0.70 & & & & & & \\
\hline & 915 & Saprolite, unit 2 & 80.1 & 11.4 & 1.9 & 0.41 & 0.18 & 0.23 & 0.07 & 0.80 & & & 0.40 & & & & & & \\
\hline & 946 & Saprolite, unit 4 & 54.9 & 17.2 & 9.7 & 1.2 & 2.6 & 4.8 & 0.11 & 1.7 & & & 0.86 & & & & & & \\
\hline & 946 & Saprolite, unit 4 & 51.3 & 17.8 & 10.3 & 1.5 & 2.7 & 5.8 & 0.71 & 2.2 & & & 0.88 & & & & & & \\
\hline & 968 & Hornblende schist & 49.6 & 15.8 & 6.9 & 3.2 & 3.1 & 8.6 & 2.0 & 2.7 & & & 1.2 & & & & & & \\
\hline & 971 & Hornblende schist & 54.7 & 17.9 & 5.1 & 2.9 & 3.2 & 7.0 & 3.2 & 2.4 & & & 0.88 & & & & & & \\
\hline $\mathrm{P} 8 \mathrm{R}$ & 760 & Saprolite, unit 1 & 80.2 & 11.7 & 0.97 & 0.37 & 0.11 & 0.13 & 0.05 & 0.1 & & & 0.67 & & & & & & \\
\hline & 765 & Saprolite, unit 1 & 53.7 & 21.1 & I3. 8 & 0.32 & 0.20 & 0.19 & 0.07 & 0.47 & & & 0.60 & & & & & & \\
\hline & 770 & Saprolite, unit 2 & 70.8 & 16.7 & 3.1 & 0.13 & 0.33 & 0.21 & 0.18 & 3.2 & & & 0.45 & & & & & & \\
\hline & 780 & Saprolite, unit 2 & 69.1 & 12.0 & 6.5 & 0.88 & 1.22 & 8.6 & 0.13 & 3.7 & & & 0.41 & & & & & & \\
\hline & 820 & Saprolite, unit 4 & 65.9 & 13.1 & 7.4 & 1.3 & 1.9 & 1.5 & 1.6 & 1.7 & & & 0.58 & & & & & & \\
\hline & 830 & Hornblende schist & 65.0 & 14.4 & 1.9 & 4.55 & 2.2 & 1.4 & 2.5 & 3.2 & & & 0.60 & & & & & & \\
\hline
\end{tabular}

* Specimens from Wells P6R, DRB 1, DRB 2, and DRB 7 were analyzed by the U. S. Geological Survey; see also Part's $B$ and $C$ of this Table.

Specimens from Wells DRB 8 and P8R were analyzed by Andrew S. MCCreath and Son, Inc. 
TABLE 5 (cont'd)

Analysis of Saprolite and Crystalline Metamorphic Rock

B. Spectrographic Analysis ${ }^{a}$

\begin{tabular}{|c|c|c|c|c|c|c|c|c|c|c|c|}
\hline \multirow[b]{2}{*}{ Welz } & \multirow[b]{2}{*}{ Depth, $f t$} & \multicolumn{10}{|c|}{ Element Concentration, wt $\%$ b } \\
\hline & & Description & $\overline{A 2}$ & $\mathrm{Ca}$ & Fe & $K$ & $M g$ & $\mathrm{Na}$ & $P$ & $S i$ & $T i$ \\
\hline \multirow[t]{4}{*}{ P6R } & 773 & Saprolite, unit 1 & 10 & 0.2 & 10 & $\mathrm{~N}$ & 0.2 & 0.05 & $\mathrm{~N}$ & $\mathrm{G}$ & 0.5 \\
\hline & 782 & Saprolite, unit 2 & 7 & 0.1 & 2 & 0.7 & 0.1 & 0.07 & $\mathrm{~N}$ & G & 0.2 \\
\hline & 830 & Saprolite, unit 4 & 10 & 0.7 & 10 & 0.7 & 1 & 1.5 & $\mathrm{~N}$ & G & 0.7 \\
\hline & 859 & $\begin{array}{l}\text { Unweathered horn- } \\
\text { blende - chlorite } \\
\text { schist }\end{array}$ & 10 & 7 & 10 & 0.7 & 7 & 2 & $\mathrm{~N}$ & G & 0.7 \\
\hline DRB 1 & 1631.7 & Hornblende schist & G & 10 & G & $\mathrm{N}$ & 10 & 1.5 & $\mathrm{~N}$ & $\mathrm{G}$ & 0.7 \\
\hline DRB 2 & 1395 & Hornblende schist & 10 & 7 & $\mathrm{G}$ & 1 & 10 & 1 & $\mathrm{~N}$ & G & 0.5 \\
\hline DRB 1 & 1746.8 & $\begin{array}{l}\text { Banded granitoid } \\
\text { gneiss and horn- } \\
\text { blende gneiss }\end{array}$ & G & 7 & 10 & $\mathrm{~N}$ & 7 & 2 & $\mathrm{~N}$ & G & 0.5 \\
\hline DRB 7 & 1743 & $\begin{array}{l}\text { Banded hornblende- } \\
\text { chlorite schist } \\
\text { and quartz - feld- } \\
\text { spar gneiss }\end{array}$ & 10 & 7 & 5 & 1.5 & 5 & 3 & $\mathrm{~N}$ & G & 0.5 \\
\hline
\end{tabular}

a. Analyzed by the U. S. Geological Survey Laboratories; same samples as in Parts A and C of this Table.

b. N - none detected; L - detected, but quantity too smal1 to measure; G - amount relatively large, but not quantitatively determined. 
TABLE 5 (cont'd)

Analysis of Saprolite and Crystalline Metamorphic Rock

C. Spectrographic Analysis

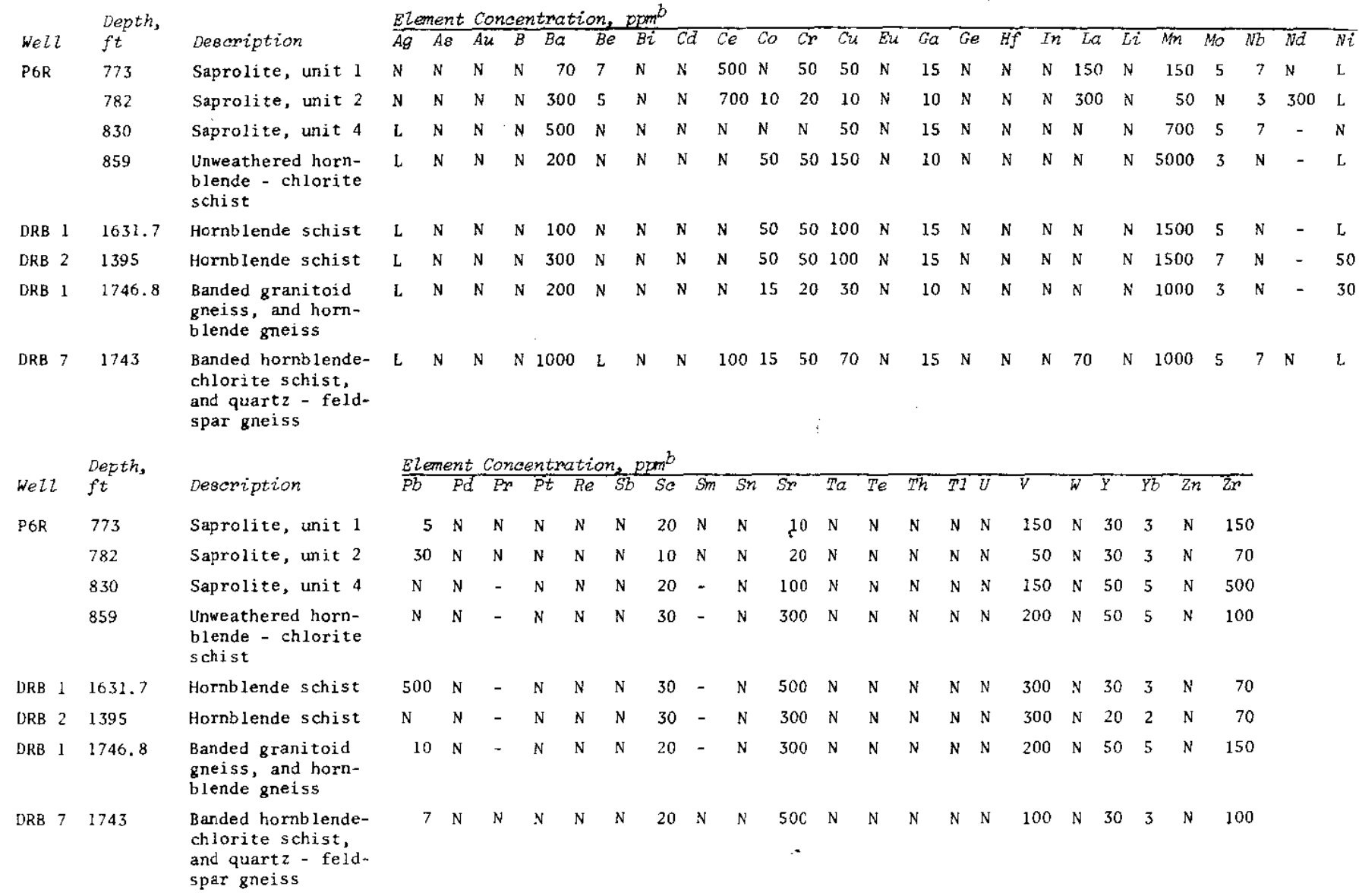

$\begin{array}{ll}\text { Well } & \begin{array}{l}\text { Depth, } \\ f t\end{array} \\ \text { P6R } \quad 773 \\ & 782 \\ & 830 \\ & 859\end{array}$

Description

Saprolite, unit 1 Saprolite, unit 2 Saprolite, unit 4 Unweathered hornblende - chlorite

DRB 1 1631.7 Hornblende schist

DRB $2 \quad 1395$

Hornblende schist

DRB $\quad 1 \quad 1746.8$ Banded granitoid gneiss, and hornblende gneiss

DRB $7 \quad 1743 \quad$ Banded hornblendechlorite schist,

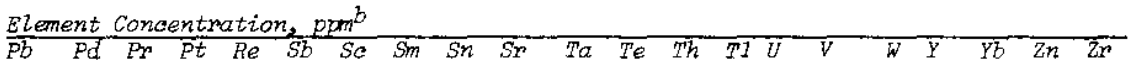
spar gneiss

a. Analyzed by the U. S. Geological Survey; same samples as in Parts A and B of this Table.

a. Analyzed by the $U$. $S$. Geological Survey; same samples as in Parts $A$ 


\section{TABLE 6}

Isotopic Composition of Argon Dissolved in Water from the Crystalline Metamorphic Rock Compared with the Isotopic Composition of Argon in Air

\begin{tabular}{lllll} 
& & \multicolumn{4}{l}{ Concentration, mol \% } \\
Source & bate & ${ }^{36} \mathrm{Ar}, \%$ & ${ }^{38} \mathrm{Ar}, \%$ & ${ }^{40} \mathrm{Ar}, \%$ \\
DRB 6 & $6-16-71$ & 0.337 & 0.068 & 99.60 \\
& & 0.335 & 0.064 & 99.60 \\
DRB 6 & $6-28-71$ & 0.339 & 0.064 & 99.60 \\
& & 0.337 & 0.066 & 99.60 \\
Air & Accepted values & 0.337 & 0.063 & 99.60
\end{tabular}

TABLE 7

Thorium, uranıum, and Helium Contentse of Selected Core Samples of Crystalline Metamorphic Rock

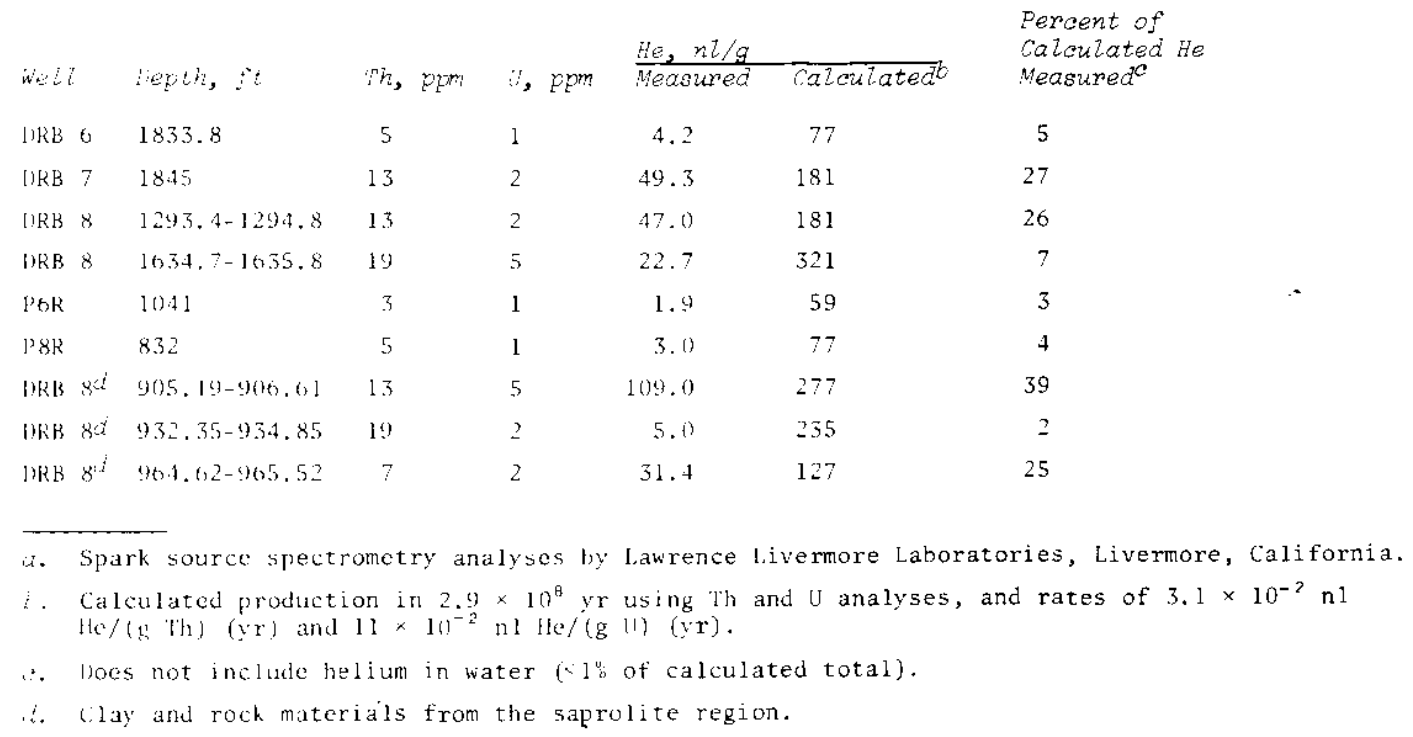




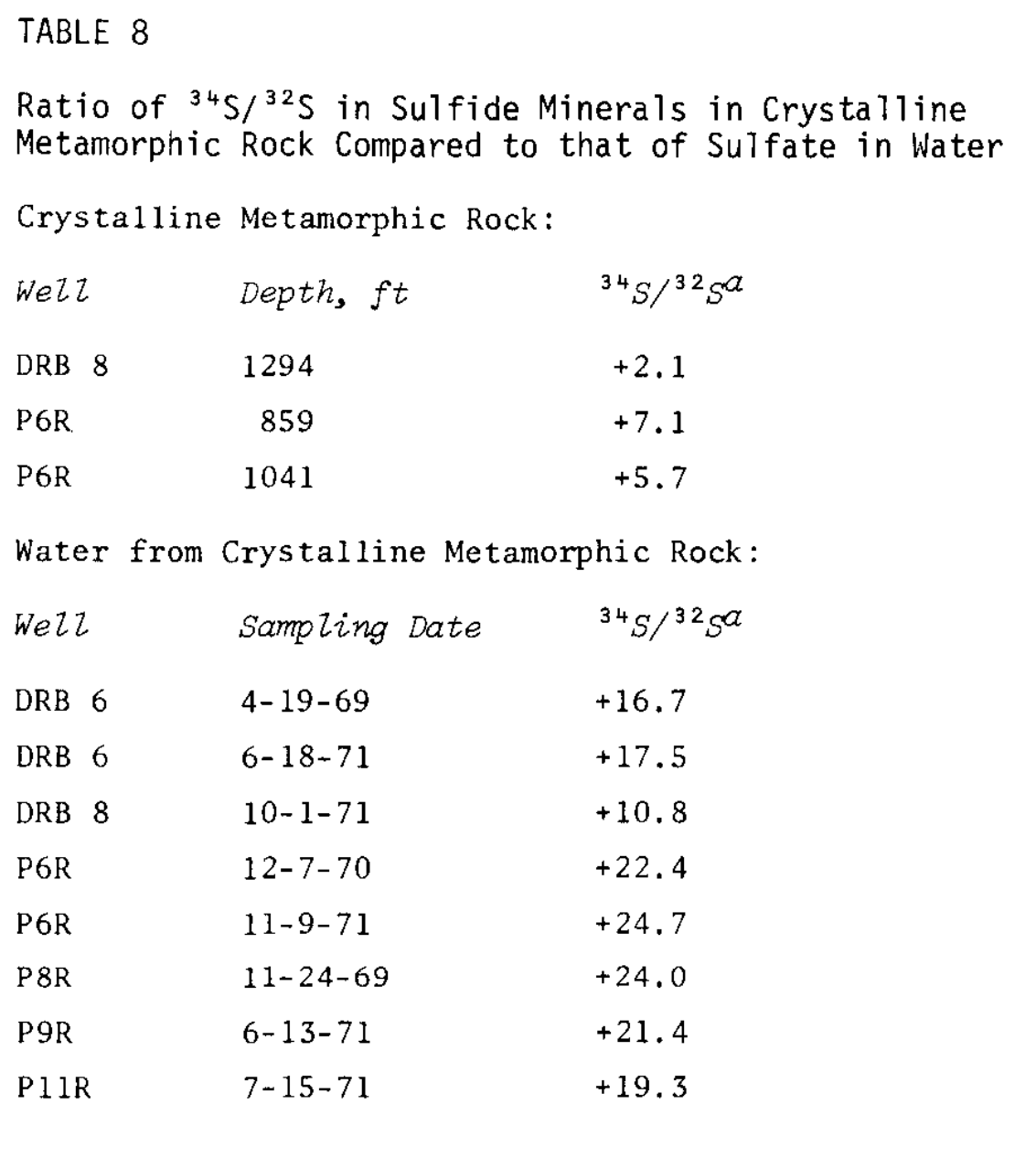

a. Expressed as parts per thousand variation from the standard, Cañon Diablo Troilite. 
TABLE 9

Range and Median Values for Chemical Constituents and Properties of Water from the Coastal Plain Sediments ${ }^{4}$

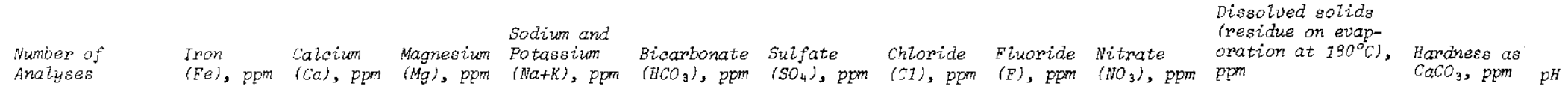
Tuscaloosa formation

$\begin{array}{llllllllllll}\text { Maximum--- } & 0.77 & 1.4 & 0.9 & 6.7 & 17 & 4.8 & 4.0 & 0.1 & 8.8 & 28 & 7 \\ \text { Median---- } & 0.16 & 0.9 & 0.5 & 2.1 & 3 & 1.4 & 2.2 & 0.0 & 0.6 & 19 & 5.9 \\ \text { Minimum--- } & 0.00 & 0.3 & 0.0 & 0.9 & 0 & 0.5 & 0.8 & 0.00 & 0.0 & 14 & 5.4\end{array}$

Ellenton Formation

\begin{tabular}{|c|c|c|c|c|c|c|c|c|c|c|c|c|c|}
\hline \multirow[t]{3}{*}{16} & Maximum--- & 4.1 & 8.7 & 1.3 & 4.2 & 23 & 27 & 6.0 & 0.2 & 0.9 & 54 & 30 & 6.8 \\
\hline & Median-... & 1.1 & 6.4 & 1.0 & 2.7 & 12 & 11 & 2.1 & 0.1 & 0.0 & 41 & 19 & 5.9 \\
\hline & Minimum--- & 0.10 & 3.9 & 0.4 & 1.5 & 4 & 7.4 & 1.5 & 0.0 & 0.0 & 36 & 10 & 4.4 \\
\hline \multicolumn{14}{|c|}{ Eocene Limestone } \\
\hline \multirow[t]{3}{*}{15} & Maximum-..- & 1.0 & 47 & 9.4 & 19 & 171 & 14 & 4.5 & 0.5 & 6.2 & 192 & 132 & 7.6 \\
\hline & Median-... & 0.25 & 27 & 2.0 & 1.7 & 94 & 4.3 & 2.8 & 0.1 & 0.2 & 95 & 72 & 7.1 \\
\hline & Mirimum--- & 0.00 & 17 & 0.3 & 0.4 & 55 & 0.8 & 0.4 & 0.0 & 0.2 & 75 & 50 & 6.8 \\
\hline \multicolumn{14}{|c|}{ Eocene Sand } \\
\hline \multirow[t]{3}{*}{9} & Maximum-.- & 1.84 & 8.7 & 4.2 & 2.4 & 17 & 9.3 & 4.0 & 0.3 & 2.3 & 29 & 15 & 6.1 \\
\hline & Median---- & 0.16 & 1.5 & 0.7 & 2.1 & 5.5 & 1.9 & 2.7 & 0.1 & 1.3 & 21 & 8 & 5.5 \\
\hline & Minimum--- & 0.04 & 0.5 & 0.3 & 0.4 & 1 & 0.8 & 1.5 & 0.00 & 0 & 20 & 4 & 4.2 \\
\hline
\end{tabular}


TABLE 10

Generalized Log of Saprolite Cores

Lithology

Depth (Tope), ft

Lithology,

$\overline{P G R}$

P7R

$\bar{P} 8 R$

DRB 8

Thickness, ft

Tuscaloosa formation

Basal aquiclude, gray clay

710

792

740

835

16-39

28

Saprolite

Unit 1 :

Mottled red, white, purple, gray and rust-colored clay with the consistency of brick

Unit 2:

Gray-green or red plastic clay, sandy clay, or clayey sand depending on whether original

rock was schist or gneiss

Unit 3:

Gray or green clay with chunks of soft, weathered schist

Unit 4:

Soft, wathered schist or gneiss

with foliation visible, but can

be scratched with fingernail.

Flaked and cracked on drying.

Entire Saprolite

745

816

756

874

$12-35$

26

780

838

768

908

$6-18$

14

ard crystalline rock

(schist, gneiss, or quartzite)

798

856

781

914

8-18

14

816

868

789

931

20- 41

29

888

$(900)^{a}$

830

83

a. Originally thought to be 888 feet; but on drying, the cores from 888 to 900 feet disintegrated, showing that hard rock began at a lower depth. 
TABLE ?

Analyses of Pore Water from Saprolite*

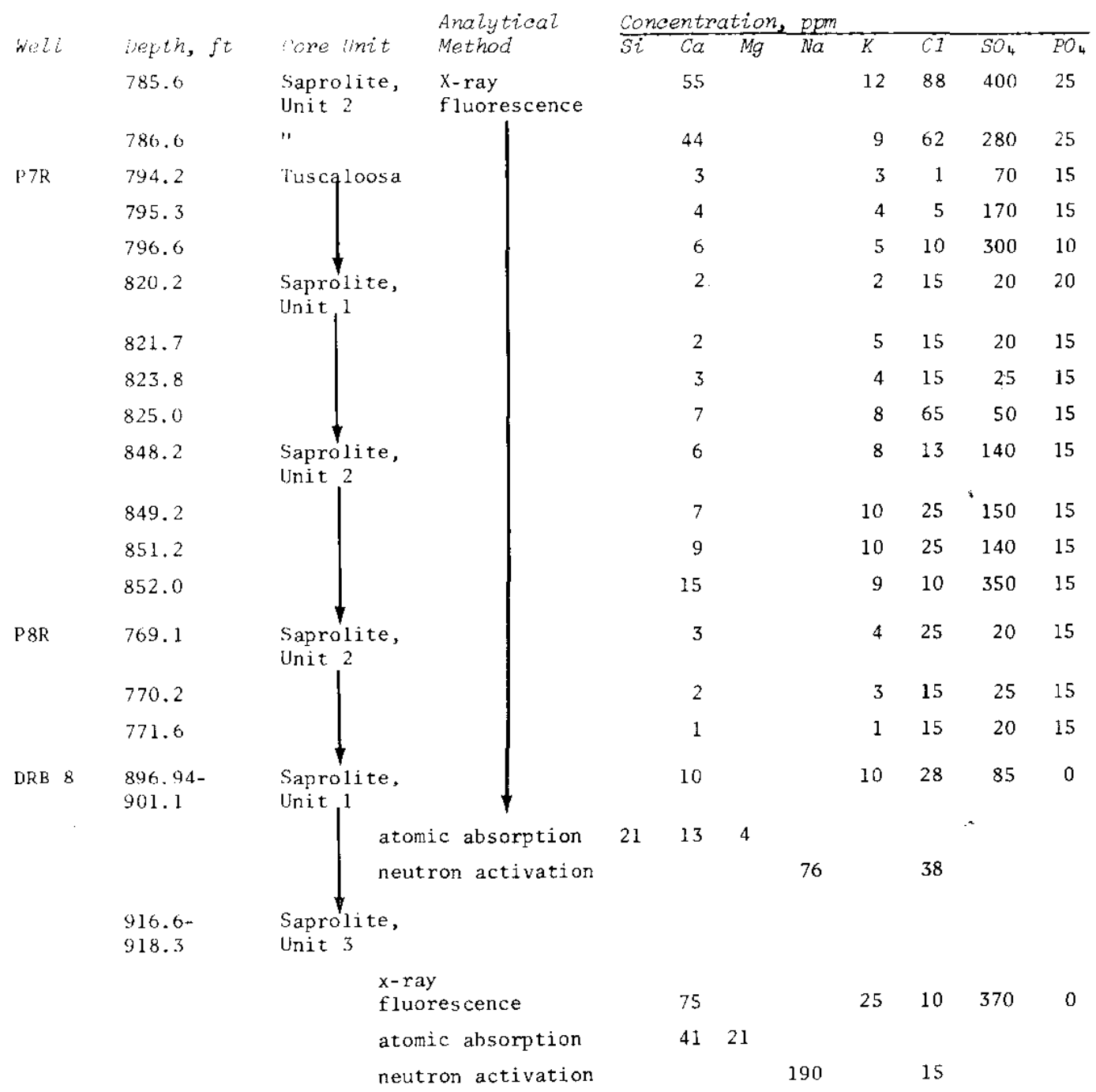

\footnotetext{
* Pore water pressed from core specimens and analyzed by USGS.
} 
TABLE 12

Electrical Conductivity of Water from DRB 11

\begin{tabular}{|c|c|c|c|}
\hline \multicolumn{2}{|l|}{ Date } & $\begin{array}{l}\text { Conductivity, } \\
\text { umhos }\end{array}$ & \multirow{2}{*}{$\begin{array}{l}\text { Remarks } \\
\text { Last drilling }\end{array}$} \\
\hline $72:$ & $12-14$ & & \\
\hline & $12-21$ & & Last work in hole with drill pipe \\
\hline & $12-26$ & 4350 & \\
\hline & $12-29$ & 4167 & \\
\hline 1973: & $1-2$ & 4545 & \\
\hline & $1-4$ & 4545 & $;$ \\
\hline & $1-8$ & 19,600 & \\
\hline & $1-10$ & 19,600 & X \\
\hline & $1-12$ & 20,400 & \\
\hline & $1-15$ & 22,990 & \\
\hline & $1-17$ & 22,470 & \\
\hline & $1-19$ & 22,470 & \\
\hline & $1-22$ & 20,800 & We11 was closed for pressure test \\
\hline & $2-21$ & 25,700 & Well was opened for flow test \\
\hline & $2-23$ & 25,000 & \\
\hline & $2-26$ & 26,670 & $\sim$ \\
\hline & $3-8$ & 25,000 & \\
\hline & $3-15$ & 28,600 & Well was closed for pressure test \\
\hline
\end{tabular}


TABLE 13

Geologic Formations Underlying SRP

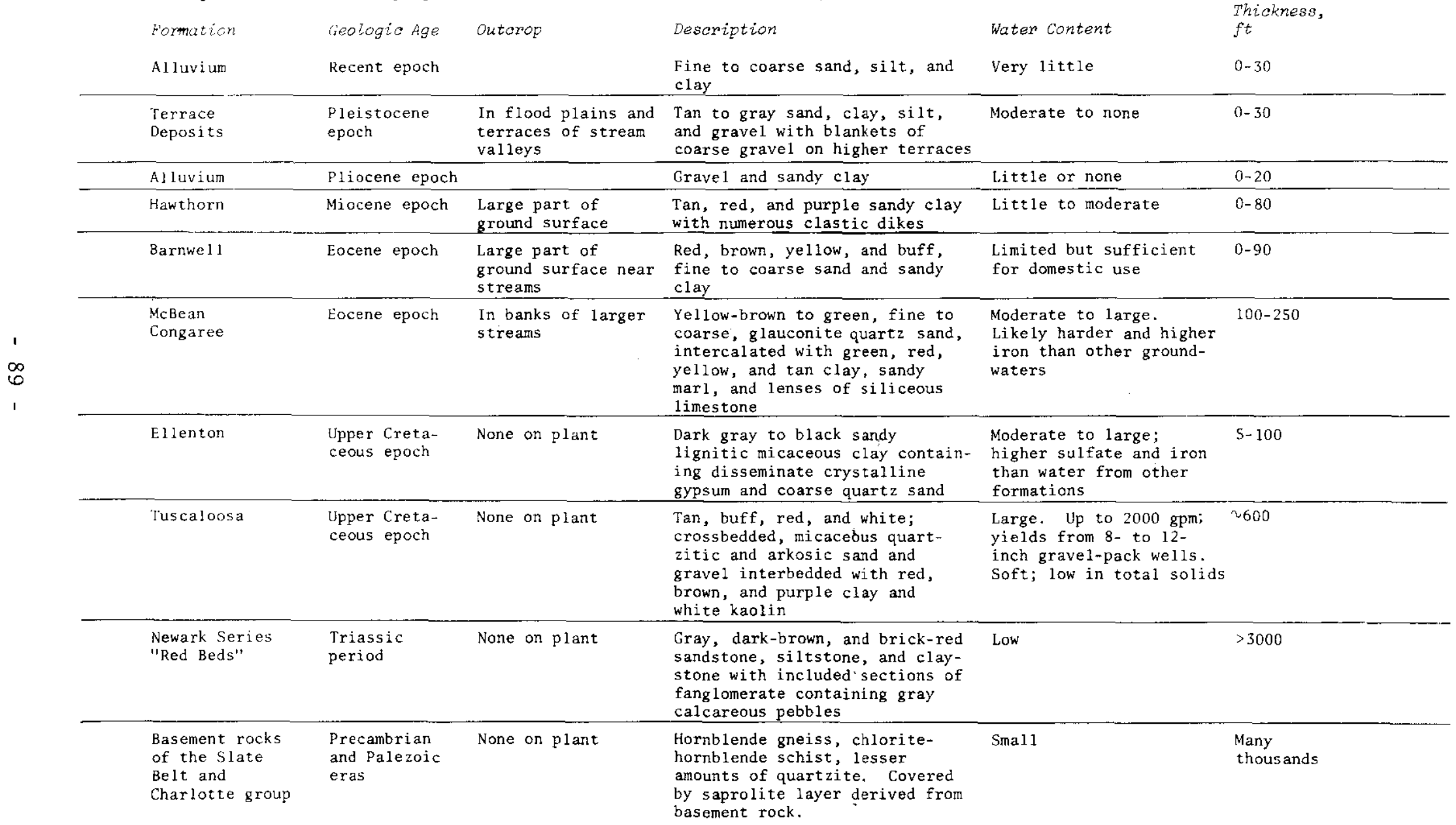


TABLE 14

Geologic-Hydrologic History of the SRP Region

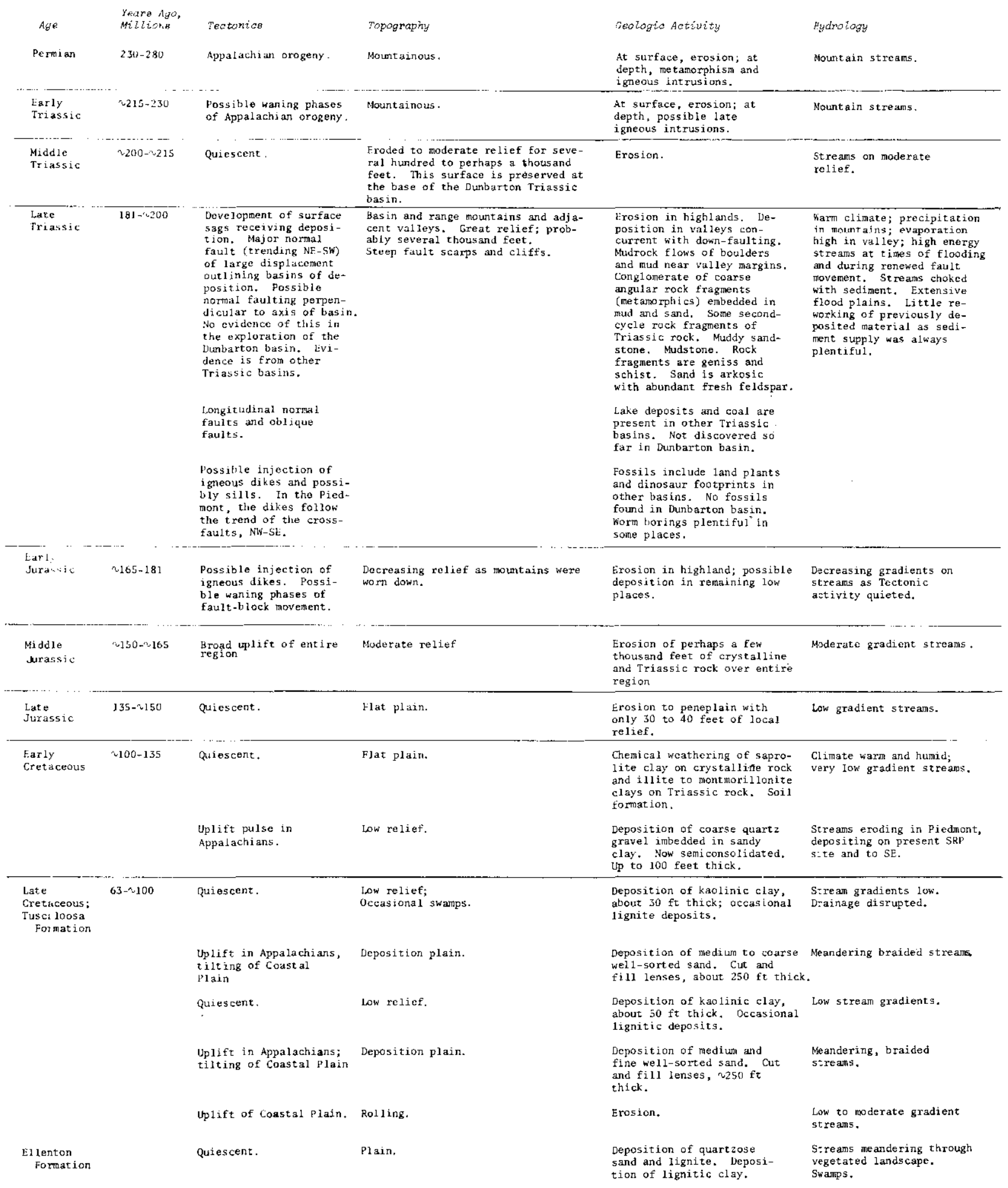


TABLF 14. Continued

\begin{tabular}{|c|c|c|c|c|c|}
\hline Aुg. & $\begin{array}{l}\text { Yeurs: Ago, } \\
\text { Aititionso }\end{array}$ & antumina & Ooprograping & Geologic Activity & Hydrology \\
\hline Fis leocese & $8 \div-6 \vdots$ & $\begin{array}{l}\text { quicstent; perbaps } \\
\text { tilting of coastal } \\
\text { jiant. }\end{array}$ & $\begin{array}{l}\text { Gently amergent plain or } \\
\text { gently submergent plain. }\end{array}$ & $\begin{array}{l}\text { Perhaps gentle erosion; } \\
\text { perhaps some marine } \\
\text { deposition; but if so, the } \\
\text { deposits were subsequent ly } \\
\text { exoded. }\end{array}$ & $\begin{array}{l}\text { Paleocene deposits in South } \\
\text { westem Georgia indicate } \\
\text { marine deposition. If the } \\
\text { sea covered the Savannah } \\
\text { River plant area, it is the } \\
\text { first incursion of the sea } \\
\text { for which any indication } \\
\text { exists since late Paleozoic } \\
\text { time. However, this area } \\
\text { may have been a site of mild } \\
\text { erosion during Paleocene } \\
\text { time. }\end{array}$ \\
\hline $\begin{array}{l}\text { rasty } \\
\text { Ziscene }\end{array}$ & $\cdot 51-38$ & 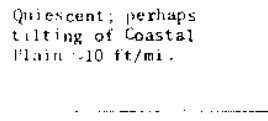 & $\begin{array}{l}\text { Gent ly energent } \\
\text { or submergent plain. }\end{array}$ & $\begin{array}{l}\text { Perhaps gentle erosion; } \\
\text { perhaps some marine } \\
\text { deposition; but if so, } \\
\text { the deposits were subse- } \\
\text { quent fy eroded. }\end{array}$ & $\begin{array}{l}\text { Lower Eocene deposits in } \\
\text { South Georgia indicate } \\
\text { near-shore deposits. }\end{array}$ \\
\hline $\begin{array}{l}\text { M1) } 1 \mathrm{da}] \mathrm{e} \\
{[.1) \operatorname{coche}}\end{array}$ & $\therefore 4-\ldots 1$ & & & & \\
\hline \multirow[t]{2}{*}{$\begin{array}{l}\text { Conguree } \\
\text { rornation }\end{array}$} & & 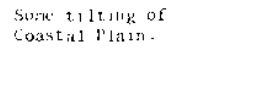 & Submergent. & $\begin{array}{l}\text { Deposition of fine to } \\
\text { medium glauconitic sand } \\
\text { interbedded with greenish- } \\
\text { tan clay. }\end{array}$ & $\begin{array}{l}\text { First indisputable evidence } \\
\text { of a marine invasion since } \\
\text { late Paleozoic time. }\end{array}$ \\
\hline & & $\mathrm{U}_{\mathrm{J}} \mathrm{ylift}$ & b:mergent. & Erasion. & Fresh water streams. \\
\hline $\begin{array}{l}\text { Mcbean } \\
\text { Format } 1 \text { in }\end{array}$ & $\ldots$ & ikgnil-wast] & Sulmergent. & $\begin{array}{l}\text { Deposition of medium to } \\
\text { coarse limey sand. }\end{array}$ & Marine, near-shore. \\
\hline $\begin{array}{l}\text { 1.ate } \\
\text { i.ocene }\end{array}$ & $3 t-\cdots 44$ & $\begin{array}{l}\text { lyplaft and thlting of } \\
\text { Coastal Hajm }-10 \mathrm{ft} / \mathrm{mi}\end{array}$ & kinergent & Erosion. & Fresh water streams. \\
\hline 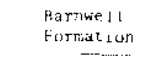 & $\cdots-\cdots$ & 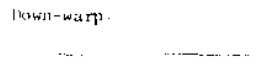 & Submergent. & $\begin{array}{l}\text { Deposition of sandy lime- } \\
\text { stone near shore. }\end{array}$ & Estuarine. \\
\hline \multirow[t]{2}{*}{ i! igocene. } & $: 5.30$ & Qujesctent & $\begin{array}{l}\text { liently cmergent or } \\
\text { submergent plain. }\end{array}$ & $\begin{array}{l}\text { Perhaps gentle erosion or } \\
\text { perhaps marine deposition } \\
\text { of sandy limestone; but if } \\
\text { so, the deposits were subse- } \\
\text { quently eroded. }\end{array}$ & $\begin{array}{l}\text { Marine. } \\
\qquad \\
\qquad\end{array}$ \\
\hline & & upditt. & Linergenț. & Erosion. & Fresh water streams. \\
\hline \multirow[t]{2}{*}{$\begin{array}{l}\text { Miciene; } \\
\text { Hawthorn } \\
\text { formation }\end{array}$} & $13-25$ & Uui escent. & probalily emergent. & $\begin{array}{l}\text { River or estuarine } \\
\text { deposition. }\end{array}$ & $\begin{array}{l}\text { Fresh water stream } \\
\text { or estuaries. }\end{array}$ \\
\hline & ..- - - . . & tplift & Emergent. & Erosion. & Fresh water streams. \\
\hline$z^{\prime}$ l 10cene & $1-15$ & $\begin{array}{l}\text { Uplitit. } \\
\text { n-_. }\end{array}$ & Emergent. & $\begin{array}{l}\text { Principally erosion but } \\
\text { some alluvial deposits. }\end{array}$ & Fresh water streams. \\
\hline $\begin{array}{l}\text { PJelstocente; } \\
\text { Hazelturst } \\
\text { ierrace }\end{array}$ & $.01-1$ & Quicscont. & $\begin{array}{l}\text { Shoreline at elevation } \\
27 \text { ft above present-day } \\
\text { seat } \mathrm{tevel} \text {. }\end{array}$ & $\begin{array}{l}\text { Deposition at shoreline } \\
\text { and below, erosion else- } \\
\text { where. }\end{array}$ & $\begin{array}{l}\text { Sea water covered Savannah } \\
\text { River Valley and much of } \\
\text { present SRP site, but high } \\
\text { areas stood as islands. } \\
\text { Shallow oquifors and Tusea- } \\
\text { loosa Formation invaded by } \\
\text { salt water, but much of the } \\
\text { Tuscaloosa aquifer north } \\
\text { and east of SRP area re- } \\
\text { mained fresh. }\end{array}$ \\
\hline $\begin{array}{l}\text { Coharie } \\
\text { ierrace }\end{array}$ & & & $\begin{array}{l}\text { Shoreline at elevation } \\
215 \mathrm{ft} \text { above present-day } \\
\text { seat-1evel. }\end{array}$ & $\begin{array}{l}\text { Deposition at shoreline } \\
\text { and below; erosion else- } \\
\text { where. }\end{array}$ & $\begin{array}{l}\text { Sea water covered Savannah } \\
\text { River Valley and wuch of } \\
\text { present SRP site, but fresh } \\
\text { water head was high enough } \\
\text { to flush salt water from } \\
\text { aquifers down to the McBean } \\
\text { formation and to flush some } \\
\text { salt water from the Tusca- } \\
\text { loosa aquifer. }\end{array}$ \\
\hline $\begin{array}{l}\text { Sunderlarth } \\
\text { Terrace }\end{array}$ & & & $\begin{array}{l}\text { Shoreline at elevation } \\
170 \text { ft above present-day } \\
\text { sea-level. }\end{array}$ & $\begin{array}{l}\text { Deposition at shoreline } \\
\text { and below; erosion else- } \\
\text { where. }\end{array}$ & $\begin{array}{l}\text { Fresh water head is now } \\
\text { sufficient to flush most } \\
\text { of atl aquifers. }\end{array}$ \\
\hline $\begin{array}{l}\text { Geterigket } \\
\text { ierrace }\end{array}$ & & . & $\begin{array}{l}\text { Shoreline at elevation } \\
145 \mathrm{ft} \text { atrove present-day } \\
\text { sea-1 wel. }\end{array}$ & $\begin{array}{l}\text { Deposition at shoreline and } \\
\text { below; erosion eIsewhere. }\end{array}$ & $\begin{array}{l}\text { Fresh water head is now } \\
\text { sufficient to flush salt } \\
\text { water from all parts of } \\
\text { all aquifers. }\end{array}$ \\
\hline $\begin{array}{l}\text { MLsumico } \\
\text { Terrace }\end{array}$ & & & $\begin{array}{l}\text { Sloureline at elevation } \\
\text { lot) ft alove present-day } \\
\text { sea-level. }\end{array}$ & $\begin{array}{l}\text { Deposition at shoreline and } \\
\text { below; crosion clsewhere. }\end{array}$ & $\begin{array}{l}\text { Fresh water con:inues to } \\
\text { flush aquifers. }\end{array}$ \\
\hline kecent & $0-0.01$ & reuiescent. & bussection by creeks. & Erosion. & $\begin{array}{l}\text { All Coastal Plain aquifers } \\
\text { are flushed witi fresh } \\
\text { water. Crystalline met- } \\
\text { amorphic rock perhaps not } \\
\text { completely flushed; Triassic } \\
\text { basin acts as isolated sys- } \\
\text { tem. }\end{array}$ \\
\hline
\end{tabular}


TABLE 15

Analysis of Leach Solutions from Ground Rock $a, b$

\begin{tabular}{|c|c|c|c|c|c|c|c|}
\hline $\begin{array}{l}\text { Ion or } \\
\text { Element }\end{array}$ & $\begin{array}{l}D R B \quad 6 \\
1464 \\
1\end{array}$ & $\frac{f t}{2}$ & $\begin{array}{l}D R B \quad 4 \\
1903 \mathrm{ft}\end{array}$ & $\begin{array}{l}\text { DRB } 10 \\
1243 \mathrm{ft} \\
\text { Sandstone }\end{array}$ & $\begin{array}{l}\text { DRB } 10 \\
1243 \mathrm{ft} \\
\text { Mudstone }\end{array}$ & $\begin{array}{l}\text { DRB } 10 \\
3087 \mathrm{ft} \\
\text { Sands tone }\end{array}$ & $\begin{array}{l}D R B \quad 9 \\
1272^{f t}\end{array}$ \\
\hline $\mathrm{Na}^{+}$ & 6.9 & 18 & 1.8 & 4.6 & 1.8 & 23 & 14 \\
\hline $\mathrm{K}^{+}$ & 3.9 & 20 & 3.1 & 3.9 & 12 & 2.7 & 12 \\
\hline $\mathrm{Ca}^{+}$ & 200 & 240 & 1.2 & 1.2 & 1.6 & 12 & 1.6 \\
\hline $\mathrm{Mg}^{2+}$ & 2.4 & 12 & 0.5 & 0.5 & 2.0 & 2.4 & 2.4 \\
\hline $\mathrm{Cl}^{-}$ & 1.8 & 1.4 & 0.2 & 0.7 & 2.8 & 7.0 & 1.4 \\
\hline $\mathrm{SO}_{4}^{2+}$ & 200 & 290 & 1.0 & 3.8 & 9.6 & 9.6 & 5.8 \\
\hline $\mathrm{Si}$ & 17 & 20 & 1.0 & 2.8 & 17 & 14 & 28 \\
\hline
\end{tabular}

a. Samples were ground and sieved to less than $177 \mu \mathrm{m} .5 \mathrm{~g}$ of each sample was placed in a polyethylene bottle with five ml of deionized water, and the mixture was agitated on a shaker for one week at room temperature. The mixtures were filtered through a $0.45 \mu \mathrm{m}$ filter, and the filtrate was analyzed by spark source mass spectrometry. The sample from DRB 6 was run in duplicate as a check on the technique.

b. Concentrations of ions reported as $\mathrm{mg} / \mathrm{l}$. 


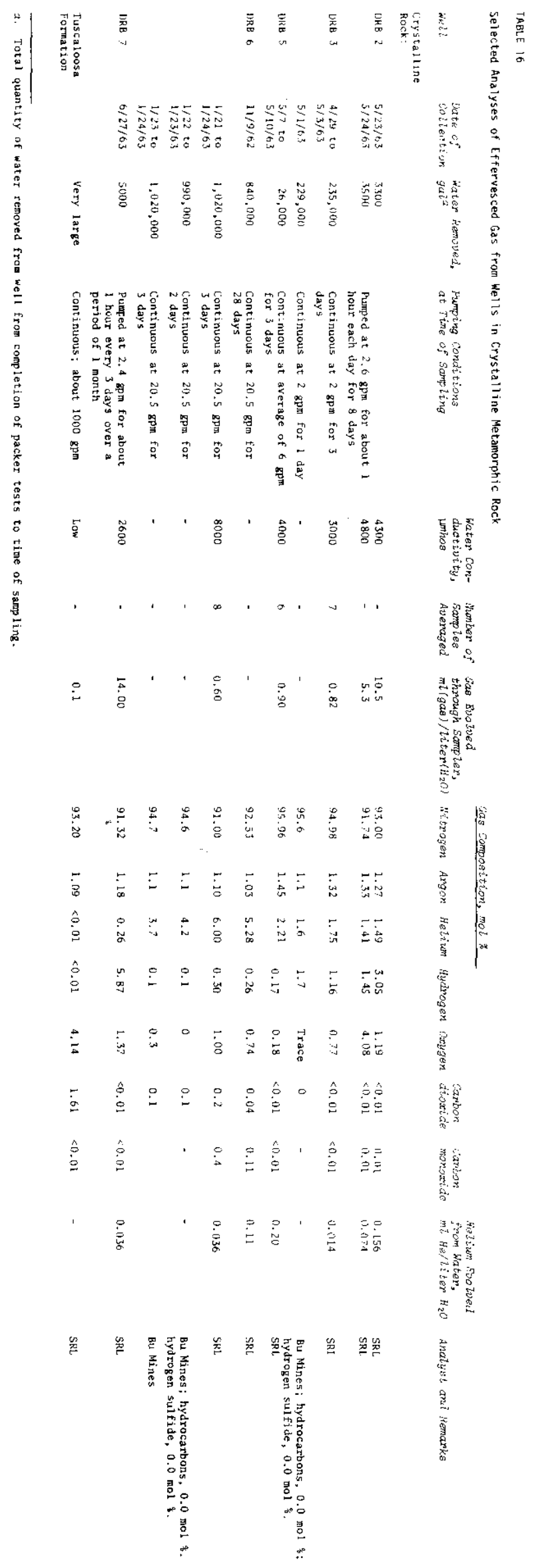


TABLE 17

Gases Dissolved in Water Samples from Wells DRB 6 and DRB 7

Volzome, ce at STP per liter of water

from Water from Gas Sample

Sample Collected Collected at

Under Pressure Atmospheric Pressure calculated from

Gas $6 / 16 / 71 \quad 6 / 28 / 71$

Helium

Argon

0.50

0.57

0.40

0.43

$1 / 23 / 63$

0.036

20.9

0.0066

18.0

0.79

0.50

0.79

0.546

0.006

0.071

0.011

0.0018

0.036

0.16

12.8

0.19

0.82

$1 / 23 / 63$

Equilibrizon

with Normal

A tmosphere

$0.058 \quad 0.06 \quad 0.00004$

$0.45 \quad 0.64 \quad 0.375$

$\begin{array}{lll}13.3 & 25.6 & 13.7\end{array}$

$0.29 \quad 0.58$

0.058

1.9

7.14

0.002

a. Data from Handbook of Chemistry and Physics. ${ }^{14}$ 
TABLE 18

Analyses of Pore Water from Tuscaloosa and Triassic Rock Samples*

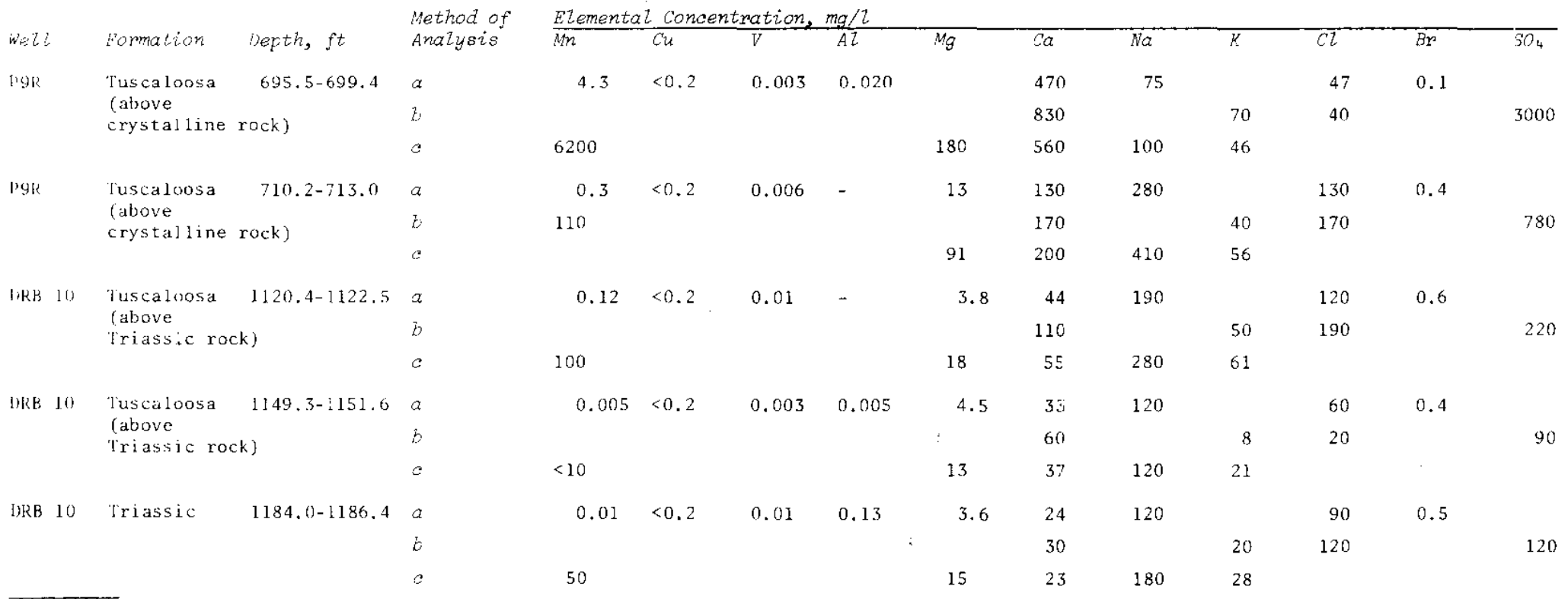

a. Neutron activation

i. X-ray fluorescence

c. Atomic absorption

* pore water pressed from core specimens and analyzed by USGS. 
TABLE 19

Analyses of Dissolved Gas in Water from Triassic Rock

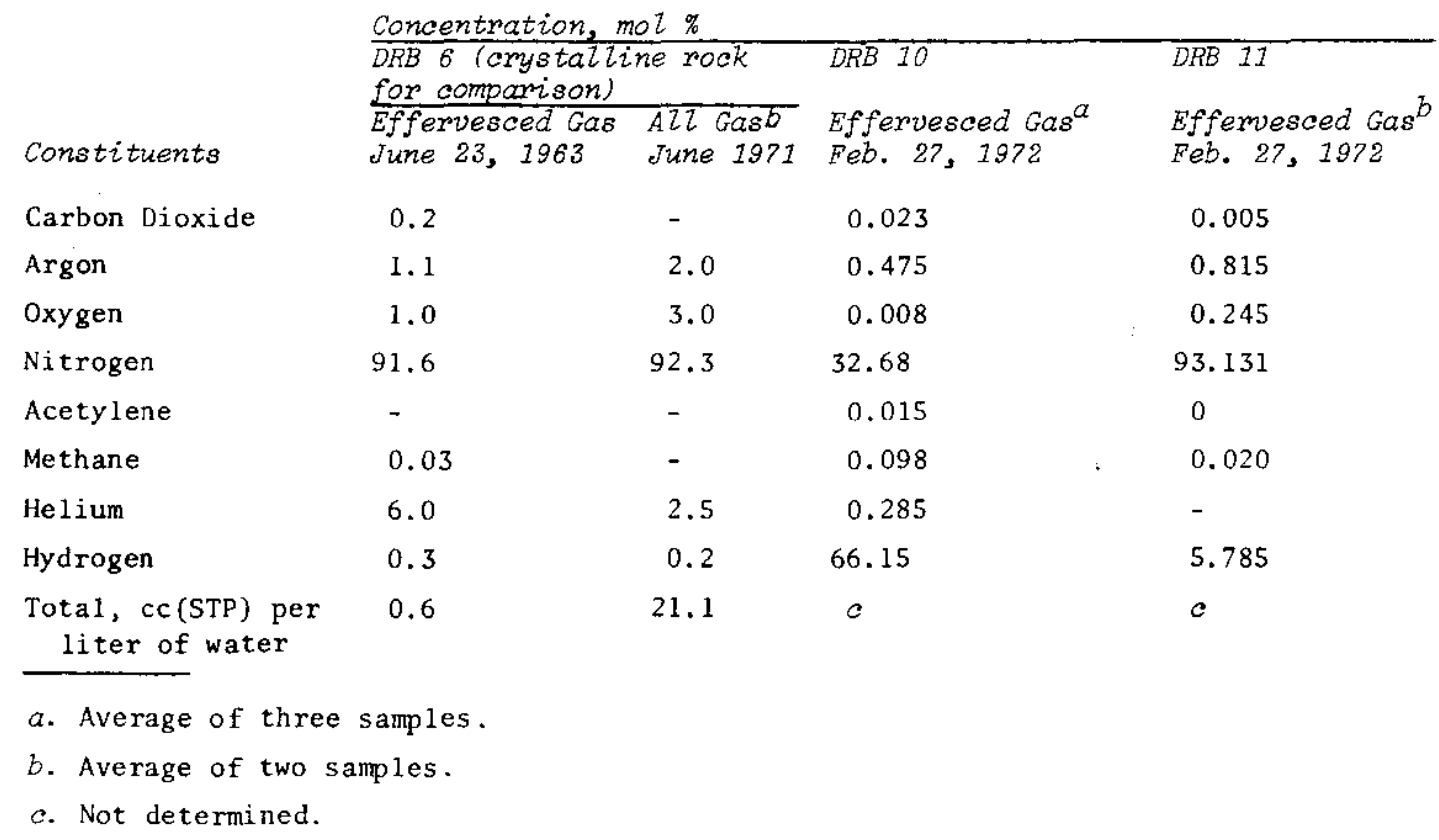


APPENDIX. Summary of Water Injected and Removed during Drilling and Testing, January 1961 to July 1973

A. Estimate of Water Injected during Drilling from January 1961 to December 1962

\begin{tabular}{|c|c|c|c|c|}
\hline \multirow{2}{*}{\multicolumn{2}{|c|}{ Wezt }} & \multicolumn{3}{|c|}{ Water Injected, gal } \\
\hline & & Upper Zone & Lower Zone & Total \\
\hline \multirow[t]{7}{*}{ DRB } & 1 & 300,000 & 25,000 & 325,000 \\
\hline & 2 & - & 3,000 & $(3,000)$ \\
\hline & 3 & 290,000 & - & 290,000 \\
\hline & 4 & 290,000 & 20,000 & 310,000 \\
\hline & 5 & 400,000 & 40,000 & 440,000 \\
\hline & 6 & 44,000 & 36,000 & 80,000 \\
\hline & 7 & - & - & $=$ \\
\hline \multicolumn{2}{|c|}{ Totals } & $\begin{array}{l}1,324,000 \\
1.3 \mathrm{mi} 11 \text { ion }\end{array}$ & $\begin{array}{l}124,000 \\
0.1 \text { mil1ion }\end{array}$ & $\begin{array}{l}1,448,000 \\
1.4 \text { million }\end{array}$ \\
\hline
\end{tabular}

B. Water Injected and Removed during Packer Tests, May 1961 to September 1962; Covers all Testing from May 1961 to April 1962.

\begin{tabular}{|c|c|c|c|c|c|c|c|}
\hline \multirow{2}{*}{\multicolumn{2}{|c|}{ We22 }} & \multirow[b]{2}{*}{ Dates } & \multirow{2}{*}{$\begin{array}{l}\text { Injection } \\
\text { Tests, gal }\end{array}$} & \multicolumn{2}{|c|}{ Swabbing Tests, gal } & \multicolumn{2}{|l|}{ Net, gaz } \\
\hline & & & & Injected & Removed & Injected & Removed \\
\hline DRB & 1 & $5-61$ & 2000 & & & 2000 & \\
\hline DRB & 2 & $\begin{array}{l}11-61 \\
3-21-62 \text { to } 4-5-62\end{array}$ & 200 & 20 & 1500 & & 1300 \\
\hline $\mathrm{DRB}$ & 3 & $\begin{array}{l}10-61 \text { and } 12-61 \\
3-1-62 \text { to } 3-15-62\end{array}$ & 500 & 0 & 5700 & $\theta$ & 5200 \\
\hline DRB & 4 & $\begin{array}{l}12-61 \\
12-61 \text { to } 1-15-62\end{array}$ & 800 & 1600 & 2000 & 400 & \\
\hline $\mathrm{DRB}$ & 5 & $9-5-62$ to $9-7-62$ & & & 3800 & & 3800 \\
\hline DRB & 6 & $6-12-62$ to $6-12-62$ & & & 6300 & & 6300 \\
\hline DRB & 7 & $6-7-62$ to $6-12-62$ & & 500 & 1700 & & 1200 \\
\hline & To & & 3500 & 2120 & 21,000 & 2400 & 17,800 \\
\hline & $\mathrm{Ne}$ & & & & & & 15,400 \\
\hline
\end{tabular}

a. No water was removed or added to any bedrock exploration we11 from June 1973 to the publication of this report in September 1976. 
C. Summary of Water Injected and Removed during Tests from April 25, 1962, through September 25, 1963

\begin{tabular}{|c|c|c|c|c|c|}
\hline & & & & Gallons & \\
\hline Activity & WeZz & Rate of Zone & Dates & Removed & Injected \\
\hline Pumping Test & $\begin{array}{ll}\text { DRB } & 3 \\
\text { DRB } & 6\end{array}$ & $\begin{array}{l}\text { Upper Zone } \\
\text { Lower Zone }\end{array}$ & $\begin{array}{l}4-25 \text { to } 5-10,1962 \\
10-12 \text { to } 11-12,1962\end{array}$ & $\begin{array}{l}200,000 \\
930,000\end{array}$ & \\
\hline Helium testing & $\begin{array}{ll}\text { DRB } & 2 \\
\text { DRB } & 3 \\
& \\
\text { DRB } & 5 \\
\text { DRB } & 6 \\
\text { DRB } & 7\end{array}$ & $\begin{array}{l}\text { Insignificant } \\
3 \text { days @ } 5 \mathrm{gpm} \\
3 \text { days @ } 2 \mathrm{gpm} \\
3 \text { days } 96 \mathrm{gpm} \\
3 \text { days } 20.5 \mathrm{gpm} \\
\text { Insignificant }\end{array}$ & $\begin{array}{l}5-17 \text { to } 5-24,1963 \\
4-26 \text { to } 4-29,1963 \\
4-30 \text { to } 5-3,1963 \\
5-7 \text { to } 5-10,1963 \\
1-21 \text { to } 1-24,1963 \\
5-27 \text { to } 7-18,1963\end{array}$ & $\begin{array}{r}3,500 \\
26,000 \\
9,000 \\
26,000 \\
90,000 \\
5,000\end{array}$ & \\
\hline $\begin{array}{l}\text { To convert water } \\
\text { in well to fresh }\end{array}$ & DRB 4P & & $4-16$ to $4-17,1963$ & & 308 \\
\hline water & DRB $4 \mathrm{C}$ & & $4-16$ to $4-17,1963$ & & 1940 \\
\hline $\begin{array}{l}\text { Dyetracer } \\
\text { injection }\end{array}$ & DRB 5 & & $10-10-62$ & & $\simeq 2750$ \\
\hline Totals & & & & $\begin{array}{l}1,350,500 \\
\sim 1.3 \text { million }\end{array}$ & $\begin{array}{r}4998 \\
\sim 5000\end{array}$ \\
\hline
\end{tabular}

D. Estimate of Water Injected and Removed during Geophys-

ical and Packer Tests (February 13 through June 11, 1964)

\begin{tabular}{|c|c|c|c|}
\hline & & Gallons & \\
\hline well & Dates & Injected & Removed \\
\hline DRB 2 & $\begin{array}{l}2-25 \text { to } 3-16 \\
6-8\end{array}$ & $\begin{array}{r}1400 \\
100\end{array}$ & \\
\hline DRB 3 & $\begin{array}{l}3-4 \text { to } 3-5 \\
6-3\end{array}$ & $\begin{array}{l}800 \\
700\end{array}$ & \\
\hline DRB 5 & $\begin{array}{l}3-8 \\
3-13 \text { to } 3-18 \\
4-20 \text { to } 5-13 \\
6-6 \text { to } 6-10\end{array}$ & $\begin{array}{r}600 \\
21,500 \\
5100\end{array}$ & 17,000 \\
\hline DRB 6 & $\begin{array}{l}3-6 \text { to } 3-7 \\
3-10 \text { to } 3-12 \\
3-20 \text { to } 5-25\end{array}$ & $\begin{array}{r}4000 \\
8500 \\
\end{array}$ & 22,500 \\
\hline Totals & & 42,700 & 39,500 \\
\hline
\end{tabular}


L. Estimate of Water Injected and Removed during Tritium Tracer Test, Long-Term Pumping Test, and brilling of Wells between June 1962 and December 1970

\begin{tabular}{|c|c|c|c|c|}
\hline & & & Gazzons & \\
\hline Activity & vates & WeZ2 & Injected & Removed \\
\hline Tracer Test & $7-22-64$ to $8-27-66$ & $\mathrm{DRB} 5$ & $8,220,000$ & \\
\hline & & DRB 6 & & $8,540,000$ \\
\hline Drilling & $9-12-67$ to $9-22-67$ & P6R & & 3,000 \\
\hline Carbon-14 sampling & $6-1-70$ to $12-14-70$ & P6R & & 10,440 \\
\hline Drilling & $10-18-67$ to $11-6-67$ & P7R & & 100 \\
\hline Hydrofracturing & $12-12-67$ to $12-17-67$ & P7R & 7,000 & 5,650 \\
\hline Dri11ing & $11-22-67$ to $12-1-67$ & $\mathrm{P} 8 \mathrm{R}$ & & 3,500 \\
\hline Packer sets & $1-14-68$ to $4-30-69$ & $\mathrm{P} 8 \mathrm{R}$ & 1,000 & \\
\hline Sampling & $10-30-69$ to $11-24-69$ & $\mathrm{P} 8 \mathrm{R}$ & & 8,250 \\
\hline Carbon-14 sampling & $3-10-70$ to $4-29-70$ & $\mathrm{P} 8 \mathrm{R}$ & & 4,090 \\
\hline Pumping test & $8-7-68$ to $10-1-69$ & DRB 6 & & $9,375,000$ \\
\hline Carbon-14 sampling & $12-17-69$ to $5-27-70$ & DRB 6 & & $2,452,000$ \\
\hline Drilling & $6-2-69$ to $6-21-69$ & DRB 8 & 33,000 & 354,000 \\
\hline After completion & $6-21-69$ to $6-22-69$ & DRB 8 & & 144,000 \\
\hline Packer testing & $3-2.3-70$ to $4-1-70$ & DRB 8 & 2,000 & \\
\hline Water removal & $6-25-70$ to $7-21-70$ & DRB 8 & & 377,300 \\
\hline Carbon-14 sampling & $7-21-70$ to $8-21-70$ & DRB 8 & & 8,800 \\
\hline Drilling & $7-8-69$ to $7-18-69$ & DRB 9 & & 13,000 \\
\hline Packer testing & $4-4-70$ to $5-11-70$ & DRB 9 & 1,000 & \\
\hline
\end{tabular}


F. Estimate of Water Injected and Removed from Bedrock Exploration Wells (January 1971 to June 1973)

\begin{tabular}{|c|c|c|c|c|}
\hline & & & Gallons & \\
\hline Activity & Dates & Wezl & Injected & Removed \\
\hline Drilling & $5-1-71$ to $7-31-71$ & DRB 10 & & 5160 \\
\hline $\begin{array}{l}\text { Intermittent sam- } \\
\text { pling and leaks }\end{array}$ & $9-30-71$ to $3-1-71$ & DRB 10 & & 1360 \\
\hline Drilling & $6-10-71$ to $6-14-71$ & P9R & & 1000 \\
\hline Drilling & $6-27-71$ to $7-14-71$ & P11R & & 600 \\
\hline Gas sampling & $6-12-71$ to $6-28-71$ & DRB 6 & & 3500 \\
\hline Gas sampling & $\begin{array}{l}9-3-71 \text { to } 9-10-71 \\
11-8-71 \text { to } 11-10-71 \\
2-16-72 \text { to } 2-20-72 \\
3-24-72 \text { to } 3-29-72 \\
4-4-72 \text { to } 4-11-72\end{array}$ & P6R & & $\begin{array}{r}1100 \\
600 \\
300 \\
1100 \\
1500\end{array}$ \\
\hline $\begin{array}{l}\text { After completion } \\
\text { of drilling }\end{array}$ & $7-4-72$ to $7-5-72$ & P12R & v & 640 \\
\hline Drilling & $7-22-72$ to $12-14-72$ & DRB 11 & & 5356 \\
\hline $\begin{array}{l}\text { Logging and } \\
\text { testing }\end{array}$ & $12-14-72$ to $12-21-72$ & & & 500 \\
\hline Flow test & $12-21-72$ to $1-22-73$ & & & 3230 \\
\hline Flow test & $2-21-73$ to $3-15-73$ & & & 2315 \\
\hline Sample collection & $4-23-73$ & & & 20 \\
\hline Valve repair & $6-1-73$ & & & 2 \\
\hline
\end{tabular}




\section{REFERENCES}

1. H. Craig. "Isotopic Variations in Meteoric Waters." Science 133 (No. 3465), 1702-1703 (1961).

2. H. Craig. "Standard for Reporting Concentrations of Deuterium and Oxygen-18 in Natural Waters." Science 133 (No. 3467), 1833-1834 (1961).

3. D. S. Webster, J. F. Proctor, and I. W. Marine. Two-WelZ Tracer Test in Fractured Crystalline Rock. U. S. Geological Survey Water Supply Paper 1544-I. U. S. Government Printing Office, Washington, D. C. (1970).

4. G. E. Siple. Geology and Ground Water of the Savannah River Plant and Vicinity, South Carolina. U. S. Geological Survey Water Supply Paper 1841. U. S. Government Printing office, Washington, D. C. (1967).

5. J. D. Hem. Study and Interpretation of the Chemical Characteristics of Natural Water. Second Ed. U. S. Geological Survey Water Supply Paper 1473. U. S. Government Printing Office, Washington, D. C. (1970).

6. J. W. Crosby and R. M. Chatters. "New Techniques of Water Sampling for Carbon-14 Analyses." J. Geophys. Res. 70 , 2839-2844 (1965).

7. H. R. Feltz and B. B. Hanshaw. Preparation of Water Sample for Carbon-14 Dating. U. S. Geological Survey Circular 480. U. S. Government Printing Office, Washington, D. C. (1963).

8. A. I. Levorsen. Geology of Petrolewn.

W. H. Freeman and Co., San Francisco (1967).

9. R. J. Christ1. Storage of Radioactive Wastes in Basement Rock Beneath the Savannah River Plant. USAEC Report DP-844, E. I. du Pont de Nemours and Company, Savannah River Laboratory, Aiken, S. C. (1964).

10. Handbook of Physical Constants (Revised Edition). S. P. Clark, Jr., Editor. Memoir 97. Geolog. Soc. Amer., New York, N. Y. (1966). 
11. R. C. Carter, D. K. Todd, G. T. Orlob, and W. S. Kaufman. Measurement of Helium in Ground Water Tracing. Sanitary Engineering Research Laboratory, University of California, Contribution No. 21. Water Resources Center, Berkeley, California (1959).

12. I. W. Marine. "Geohydrology of the Buried Trlassic Basin at the Savannah River Plant, South Carolina." Amer. Assoc. Petrol. Geol. BuZZ., 58, (9), 1825-1837 (1974).

13. J. A. Reinemund. Geology of the Deep River Coal Field, North Carolina. U. S. Geological Survey Professional Paper 246, p 155. U. S. Government Printing Office, Washington, D. C. $(1955)$.

14. Handbook of Chemistry and Physics. R. C. Weast, Ed. 47th Edition. Chemical Rubber Co., Cleveland, Ohio (1966). 